Barbara Fialho Carvalho Sampaio

\title{
DESENVOLVIMENTO DE ENSAIOS IMUNOENZIMÁTICOS PARA OTIMIZAÇÃO DA DETECÇÃO DE IgG anti-T.gondii EM SALIVA HUMANA
}

Dissertação apresentada ao Instituto de Medicina Tropical de São Paulo da Universidade de São Paulo para obtenção do título de Mestre em Ciências.

Área de Concentração: Doenças Tropicais e Saúde Internacional.

Orientador: Prof. Dr. Heitor Franco de Andrade Júnior

São Paulo 


\section{Universidade de São Paulo \\ Instituto de Medicina Tropical de São Paulo}

\section{Candidata: Barbara Fialho Carvalho Sampaio}

Título da Dissertação: "Desenvolvimento de ensaios imunoenzimáticos para otimização da detecção de IgG anti-T.gondii em saliva humana."

Orientador: Prof. Dr. Heitor Franco de Andrade Júnior

A Comissão Julgadora dos trabalhos de Defesa da Dissertação de Mestrado, em sessão pública realizada em ........................, considerou

\section{( ) APROVADA ( ) REPROVADA}

Examinador (a)

Assinatura:

Nome:

Instituição:

Examinador (a)

Assinatura:

Nome:

Instituição:

Presitente

Assinatura:

Nome:

Instituição: 
Se...

se eu pudesse déxar algum presente a vocês,

deixaria acesso ao sentimento de amar a vida dos seres humanos.

A consciêncía de aprender tudo o que foi ensinado pelo tempo a fora...

Lembraría os erros que foram cometidos para que não mais se repetissem.

A capacidade de escolher novos rumos.

Déixaría para vocês, se pudesse, o respeito àquillo que é indispensável:

Além do pão, o trabalho.

Além do trabalho, a ação.

E, quando tudo mais faltasse, deixaria um segredo:

o de buscar no interior de si mesmo

a resposta e a força para encontrar sempre uma saida. 
Dedicatóría

Aos mens filhos Ana clara e Guilherme, por íluminar minha vida com um simples e singelo sorriso.

Ao meu marido waldir Jr. por fazer parte da minha vida e sempre me apoiar. Te amo!

Aos meus pais josé e cleusa por me apoiar desde o princípio.

Ao meu irmão Bruno por estar sempre ao meu lado.

Dedico a vocês este trabalho com todo amor do mundo...

Muito obrigada! 
Agradeço primeiramente a Deus, por dar-me a vida, por proporcionar-me sabedoría e calma quando necessário e entusiasmo diante dos obstáculos que surgiram no decorrer desse trabalho. 


\section{Agradecimento}

Ao Prof. Dr. Heitor Franco de Andrade Jr., eu agradeço pelos ensinamentos no decorrer destes 8 anos de convivência e por colaborar para a minha formação e todo conhecimento adquirido neste período. Poucos são os que merecem o título de professor, porque ensinar o que se sabe é fácil, mas permitir que aprendamos sempre, sem limite, são poucos. Ao Professor Heitor minha gratidão.

Á Profa. Dra. Luciana R. Meireles J. Ekman eu agradeço por toda dedicação na coorientação deste trabalho, pelos ensinamentos e amizade. Nunca vou esquecer tanta dedicação e carinho para a realização deste trabalho.

Às minhas amigas Marina, Bruna, Ivani, Maria, Camila, Juliana, pelo apoio em todas as horas dentro e fora do laboratório.

À Jaqueline P. Rodrigues, pela colaboração com a conjugação do antígeno biotinilado.

Aos colegas do laboratório de Protozoologia, agradeço a todos.

À Dona Fran (in memorian), pela preparação dos materiais. Muita saudades.

À Roselaine P. A. Cardoso, pelo auxílio técnico e muitas conversas.

À Silvia Leopoldino, pela preparação dos materiais. 
À Solange F. F. dos Santos e Luciano M. da Silva, pelo auxílio nas partes burocráticas.

Aos Bibliotecários do Instituto de Medicina Tropical de São Paulo, por toda ajuda na correção desse trabalho Sonia Pedrozo Gomes e Carlos José Quinteiro.

A todos vocês muito obrigada. 


\section{RESUMO}

Sampaio BFC. Desenvolvimento de ensaios imunoenzimáticos para otimização da detecção de IgG anti-T.gondii em saliva humana (dissertação). São Paulo: Instituto de Medicina Tropical de São Paulo da Universidade de São Paulo; 2012.

A toxoplasmose afeta cerca de um bilhão de pessoa em todo mundo, é geralmente assintomática, apesar de doença ocular ou doenças grave e letal em fetos, pacientes com HIV e transplantados. A sorologia é a principal ferramenta para o diagnóstico e determinação de incidência, que é uma tarefa difícil, devido à alta prevalência na maioria dos países. Estudos de incidência são ideais em crianças, mas este grupo é protegido pela sociedade e de difícil abordagem por métodos invasivos como a punção venosa. A saliva pode ser uma ótima alternativa por sua coleta não ser invasiva, aceitável para crianças, e conter pequenas quantidades de lgG, eliminada através da mucosa gengival e fluido crevicular. Métodos de detcção de anticorpos disponíveis no mercado estão focados em amostras de soro, com baixa sensibilidade e são raros os relatos de pesquisas com material biológico alternativo, como a saliva. Sendo assim, padronizamos imunoensaios com alta sensibilidade para detecção de anticorpos anti$T$. gondii na saliva frente a amostras de soro de 20 voluntários adultos. A sensibilidade e especificidade dos nossos dot-ELISA e ELISA de captura com proteína A foram semelhantes entre soro e saliva. Também testamos 100 amostras de saliva de universitários em nossos ensaios, onde mostramos uma frequência da toxoplasmose de 19\% (IC 95\% 12-28\%). Imunoensaios para detecção de IgG anti- T. gondii em saliva são uma ferramenta muito promissora para estudos epidemiológicos da toxoplasmose em crianças ou outros grupos protegidos.

Descritores: Toxoplasmose (diagnóstico); Detecção de IgG; Proteína A; Saliva; Imunoensaios; dot-ELISA. 


\begin{abstract}
Sampaio BFC. Development of immunoassays for optimizing the detection of IgG antiT. gondii in human saliva. (dissertação). São Paulo: Instituto de Medicina Tropical de São Paulo da Universidade de São Paulo; 2012.

Toxoplasmosis that affects about one billion people worldwide is usually asymptomatic, despite ocular disease and severe and lethal disease in fetuses, AIDS patients and transplant recipients. Serology is the main approach for diagnosis and incidence determination is a difficult task due to high prevalence in most countries. Incidence studies are feasible in children but this age group is protected and difficult to approach by invasive methods as venipuncture. Saliva could be obtained by non-invasive procedure, acceptable for children, and it contains small amounts of $\lg$ G from mucosal and gingival crevicular fluid. Available antibody detection methods are focused in serum samples, with low sensitivity and few reports of alternative biological material, like saliva. Here, we standardized immunoassays with high sensitivity for detection of anti-T. gondii lgG in paired saliva and serum sample from 20 adult volunteers, which allows DOT-ELISA and a Protein A IgG capture assay. The sensitivity and specificity of the saliva DOT-ELISA were similar to sera ELISA. We also tested 100 saliva samples from university graduates in all assays, showing $19 \%(95 \% \mathrm{Cl} 12-28 \%)$ frequency of toxoplasmosis in this group, lower than reported for our area. Protein A IgG capture saliva assay was also efficient with similar results. Immunoassay with saliva IgG for toxoplasmosis is a very promising tool for use for the epidemiology of toxoplasmosis in children or other protected groups.
\end{abstract}

Discriptors: Toxoplasmosis(diagnostic); IgG detection; Protein A; Saliva; immunoassays; dot-ELISA. 


\section{LISTA DE FIGURAS}

Figura 1 Morfologia esquemática de T. gondii.......................................... 16

Figura 2 Ciclo do Toxoplasma gondii.............................................. 17

Figura $3 \quad$ Formas do T. gondii............................................................ 18

Figura 4 Proteína A de Staphylococcus aureus ligada a um fragmento da região $\mathrm{Fc}$ da $\lg \mathrm{G}$.

Figura 5 Proteína A ligada a um fragmento da região Fc de IgG humana....

Figura 6 Metade direita da cabeça, seccionada no plano mediano, mostrando as glândulas submandibular e sublingual com seus ductos.

Figura 7 Fotos da confecção do kit-coleta de saliva

Figura 8 Distribuição de proteína total em saliva de voluntários, determinada pelo método de Bradford, 1 a 20 amostras de saliva.

Figura 9 Padronização da determinação de $\lg G$ humana a partir de adsorção a suporte sólido e ELISA.

Figura 10 Distribuição da concentração total de $\lg G$ humana em saliva (1 ao 20) de voluntários, determinada por adsorção e ELISA direto. As barras representam o desvio de duas medidas independentes......

Figura 11 Relação entre a proteína e a IgG em saliva humana de voluntários, mostrando a ausência de correlação entre as medidas.

Figura 12 Quantidade de IgG total em 02 voluntários que se submeteram a coleta seriada de saliva pré e pós uso de enxaguante oral. Os resultados são apresentados como média da D.O. de ELISA direto e a barra representa o erro padrão da média em 02 medidas.

Figura 13 Concentração de $\lg G$ e de $\lg G$ específica contra T.gondii após vários tipos de coleta (s enx + ou - sem enxaguante positivo ou negativo; c enx + ou - com enxaguante positivo ou negativo; c enx $2 \mathrm{~m}+$ ou - com enxaguante positivo ou negativo após 2 min. e c enx $5 \mathrm{~m}+$ ou - com enxaguante positivo ou negativo após $5 \mathrm{~min}$.) em voluntários positivos ou negativos para toxoplasmose.

Figura 14 Resultados do teste imunoenzimático ELISA para amostras de soro humano. Com quatro positivos e 16 negativos para infecção do T. gondii. 
Figura 15 Resultados do teste imunoenzimático ELISA para amostras de saliva humana. Com quatro positivos e 16 negativos para infecção do T. gondii.....

Figura 16

Resultado dot-ELISA com antígeno salino, utilizando amostras de soro e saliva de voluntários do Laboratório de Protozoologia IMT - SP. As setas indicam as amostras positivas

Figura 17 ELISA direto de antígeno de T.gondii biotinilado aderido ao suporte sólido e revelado com concentração fixa de avidina peroxidase.

Figura 18 Resultados do teste imunoenzimático ELISA de captura para amostras de soro humano, utilizando antígeno de $T$. gondii biotinilado, revelado com TMB (A) e OPD (B). 1 - Amostras negativas para $\lg G \operatorname{Tg}(n=16)$ e 2 - Amostras positivas para IgG $\operatorname{Tg}(n=4)$.

Figura 19 Resultados do teste imunoenzimático ELISA de captura para amostras de saliva humana, utilizando antígeno de $T$. gondii biotinilado, revelado com TMB (A) e OPD (B). 1 - Amostras negativas para $\lg G \operatorname{Tg}(n=16)$ e 2 - Amostras positivas para $\lg G$ $\operatorname{Tg}(n=4)$.

Figura 20 Resultado dot-ELISA Proteína A, utilizando amostras de saliva de voluntários do Laboratório de Protozoologia - IMT - SP. As setas indicam as amostras positivas (marcação de dois dots).

Figura 21 Resultados do teste imunoenzimático ELISA de captura para 100 amostras de saliva humana, utilizando antígeno de $T$. gondii biotinilado, revelado com TMB e OPD

Figura 22 Distribuição de resultados quantitativos no ELISA de captura, utilizando TMB e OPD, discriminados pelo resultado putativo de positividade no TMB, em 100 amostras de saliva humana, utilizando antígeno de $T$. gondii biotinilado e avidina peroxidase. Os cut-offs utilizados foram calculados com base nas amostras negativas, pela soma de 2 desvios padrões à media dos valores.

Figura 23 Resultado dot-ELISA Proteína A, utilizando 100 amostras de saliva de voluntários. As marcações com dois dots indicam as amostras positivas (19) e marcações com um dot indicam amostras negativas (81) 


\section{LISTA DE TABELAS}

Tabela 1 Prevalência de anticorpos IgG anti - Toxoplasma gondii em indivíduos adultos em vários países...............................

Tabela 2 Propriedades químicas e biológicas das classes lg............. 26

Tabela 3 Resultados de sensibilidade relativa, especificidade relativa, valor preditivo positivo e valor preditivo negativo do teste ELISA de captura utilizando o cromógeno TMB.....

Tabela 4 Resultados de sensibilidade relativa, especificidade relativa, valor preditivo positivo e valor preditivo negativo do teste ELISA de captura utilizando o cromógeno OPD..... 


\section{SUMÁRIO}

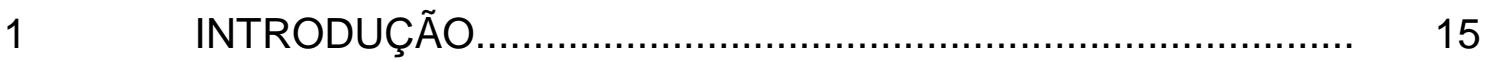

$1.1 \quad$ Ciclo de vida do T.gondii e fontes de infecção........................... 17

$1.2 \quad$ Aspectos epidemiológicos.................................................... 19

$1.3 \quad$ Formas clínicas.................................................................. 23

1.3.1 Toxoplasmose em indivíduos imunocompetente........................ 23

1.3.2 Toxoplasmose em indivíduos imunodeprimidos........................ 23

1.3.3 Toxoplasmose congênita........................................................ 24

1.3.4 Toxoplasmose ocular...................................................... 25

$1.4 \quad$ Resposta imunológica....................................................... 26

$1.5 \quad$ Emprego da proteína A em ensaios sorológicos......................... 27

$1.6 \quad$ Diagnóstico laboratorial....................................................... $\quad 30$

1.6.1 Detecção de anticorpos anti-T.gondii em soro............................ 30

1.6.2 Caracterização da saliva......................................................... 33

1.6.3 Detecção de anticorpos anti-T.gondii em saliva........................ 36

$1.7 \quad$ Prevenção e tratamento........................................................ 40

2 JUSTIFICATIVA...................................................... 44

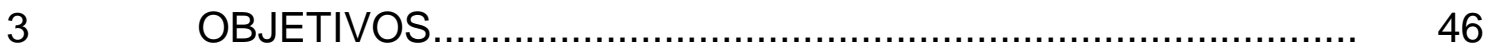

$4 \quad$ MATERIAL E MÉTODO................................................... 4

$4.1 \quad$ População estudada........................................................... 47

4.2 Organização e elaboração do "kit coleta de saliva"..................... 47

4.3 Coleta das amostras de saliva................................................ 48

$4.4 \quad$ Parasitas........................................................................ 49

4.5 Extratos antigênicos de T.gondii.......................................... 50

4.5.1 Antígeno salino................................................................. 50

4.5.2 Antígeno biotinilado para ensaio de captura de IgG por proteína A ........................................................................... 50

4.6 Dosagem protéica................................................................. 51

4.7 Ensaios imunoenzimáticos.................................................... 51

4.7.1 ELISA (Enzyme - Linked Immunosorbent Assay).................... 51

4.7.2 ELISA de captura........................................................... 52

4.7.3 dot-ELISA .......................................................................... 53

4.7.4 Determinação da concentração $(\mu \mathrm{g} / \mathrm{mL})$ de $\lg G$ anti-T.gondii... $\quad 54$

$5 \quad$ ANÁLISE ESTATÍSTICA.................................................... 55

$6 \quad$ RESULTADOS ......................................................... 56

6.1 Proteína total e lgG em saliva............................................. 56

6.2 Comparação das formas de coleta da saliva $\lg G$ total e $\lg G$ anti - T. gondii......

6.3 ELISA convencional "Padrão ouro" para determinação de anticorpos anti $-T$. gondii..

6.4 Determinação de IgG Específico por dot - ELISA.....................

6.5 Captura com proteína A........................................................... 66

6.5.1 Diluição antígeno anti- T. gondii biotinilado.............................. 66

6.5.2 ELISA de captura soro.......................................................... 67

6.5.3 ELISA de captura saliva...................................................... 69

6.5.4 dot - ELISA proteína A...................................................... 71 
6.6 Aplicação da técnica de ELISA captura e dot-ELISA nas 100 amostras..................................................................... 72

6.6.1 ELISA captura em saliva de universitários............................... 72

6.6.2 dot - ELISA proteína A 100 amostras de saliva........................ $\quad 74$

6.6.3 Índices de eficiência das reações de ELISA captura, utilizandose o dot-ELISA como padrão ouro............................................. 77

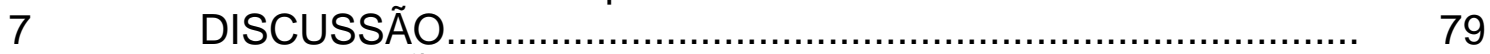

$8 \quad$ CONCLUSÃO

REFERÊNCIAS............................................................. 89

ANEXOS 112 


\section{INTRODUÇÃO}

Toxoplasma gondii foi descoberto em 1908, por Splendore no Brasil, e simultaneamente no Instituto Pasteur na Tunísia, pelos pesquisadores Nicolle e Manceaux (Splendore, 1908; Nicolle e Manceaux, 1908).

As primeiras implicações da doença humana datam de 1923, quando Jankü observou cistos de $T$. gondii na retina de uma criança de 11 meses com hidrocefalia e microftalmia (Jankü, 1923). Dez anos mais tarde, foi descrita a doença congênita causada pelo Toxoplasma (Wolf e Cowen, 1937) e, na década de 40, a infecção adquirida foi descrita em um paciente adulto, que faleceu da toxoplasmose disseminada (Pinkerton e Weinman, 1940).

Entretanto, a freqüência da infecção humana só foi conhecida a partir de 1948 com a introdução do clássico teste do corante de Sabin e Feldman (Sabin e Feldman, 1948). Tal reação contribuiu tanto para a realização de inquéritos epidemiológicos, quanto para o diagnóstico sorológico da toxoplasmose.

T. gondii pertence ao filo Apicomplexa, classe Sporozoa, subclasse Coccidia e ordem Eucoccidia, sendo a única espécie do gênero Toxoplasma (Tenter e Johnson, 1997).

Sabin, em 1939, revelou que o Toxoplasma isolado de seres humanos e aqueles previamente obtidos a partir de animais pertenciam à mesma espécie.

Por ser uma doença cosmopolita, era esperado que o T. gondii possuísse uma variedade de genótipos, fase sexuada em seu ciclo de vida e múltiplos hospedeiros. Após alguns estudos moleculares, essa espécie de coccídeo foi caracterizada por uma baixa diversidade genotípica, com evolução clonal de suas linhagens, sendo classificadas como I, II e III (Howe e Sibley, 1995). Estudos

recentes, baseados em novos marcadores para caracterização genética, têm 
revelado uma maior variabilidade dos genótipos, principalmente em cepas isoladas no Brasil (Pena et al., 2008).

O parasita apresenta uma forma estrutural (figura 1), contendo anel polar, conóide, microtúbulos, micronemas, micropolos, grânulos densos, roptrias e membrana tripla, sendo essas estruturas formadas por proteínas responsáveis pela invasão, formação de vacúolo parasitóforo e manutenção do parasita na célula hospedeira (Hiil et al., 2005).

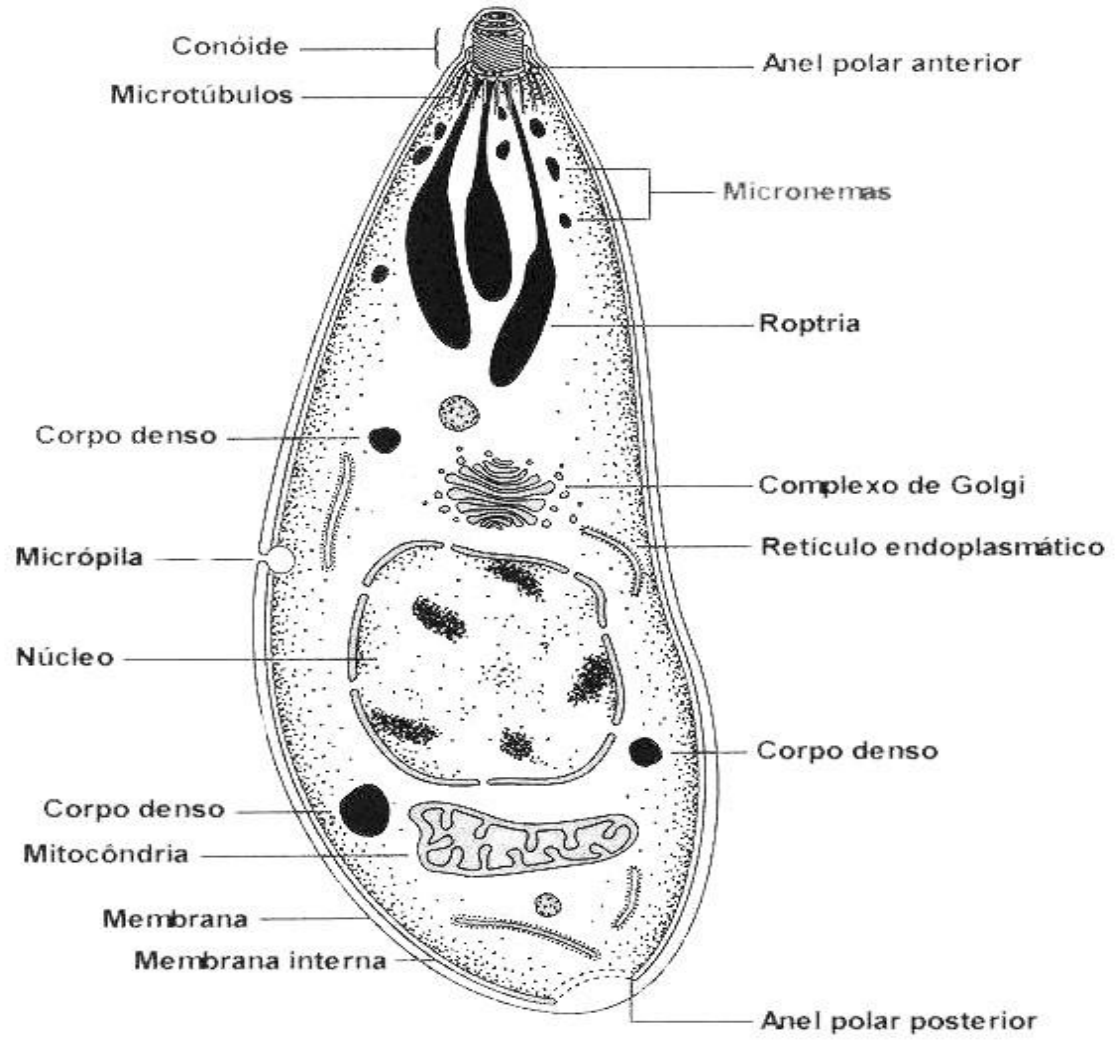

Fonte: Acervo do Laboratório de Protozoologia do IMTSP.

Figura 1 - Morfologia esquemática de T. gondii. 


\subsection{Ciclo de vida do T.gondii e fontes de infecção}

O ciclo de vida do T. gondii (figura 2) é complexo porque possui múltiplos hospedeiros. Ele compreende uma fase sexuada, que ocorre exclusivamente no tecido enteroepitelial de felinos, resultando na produção de oocistos, e uma assexuada, que pode ocorrer tanto em tecidos de felinos como de outros hospedeiros considerados intermediários, entre eles aves e mamíferos, incluindo o homem, culminando na produção de cistos teciduais (Dubey, 1998).

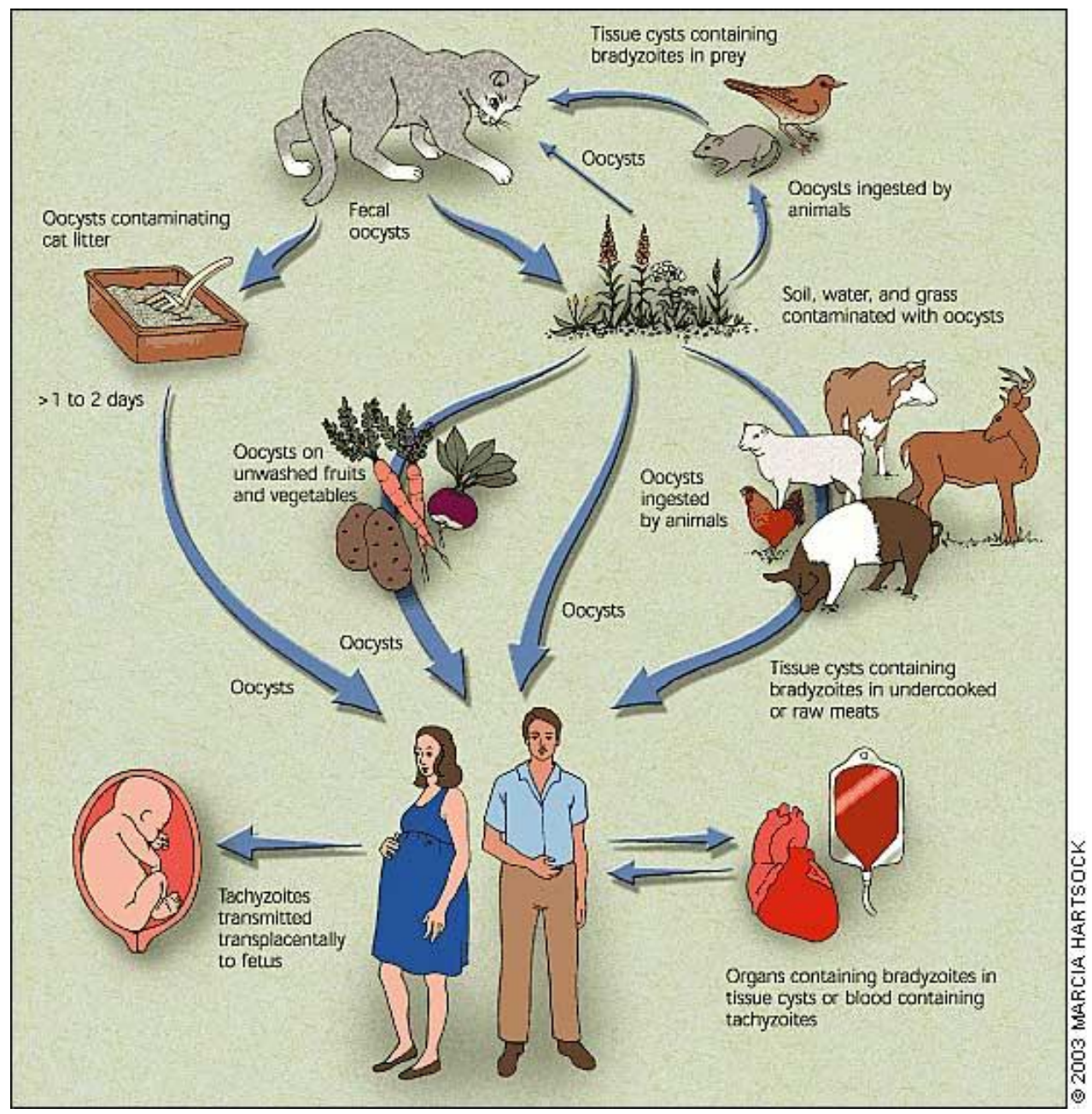

Fonte: Marcia Hartsock, 2003.

Figura 2 - Ciclo do Toxoplasma gondii. 
O ciclo de vida do T. gondii compreende as três formas evolutivas (figura 3), que são infectantes para os hospedeiros suscetíveis. Dentre estas formas, destacam-se os taquizoítos, presentes em órgãos, sangue e secreções, sendo característicos da fase aguda da infecção. Os taquizoítos apresentam multiplicação rápida, podendo ser encontrados em quase todas as células do hospedeiro. Além disso, estas estruturas podem permanecer ativas no hospedeiro por apenas algumas horas, sendo incapazes de proliferar sem penetrarem em novas células (Amato Neto et al., 1995; Andrade et al., 2000). Outras formas importantes são os bradizoítos, presentes em cistos teciduais, principalmente durante a fase crônica da doença (Ambroise, 2000). Os cistos contendo os bradizoítos possuem membrana dupla, sendo resistentes às enzimas proteolíticas e ao pH ácido do estômago, permanecendo nos tecidos por longo tempo, ou até mesmo por toda a vida dos indivíduos infectados. Estas estruturas estão presentes, com maior freqüência, em órgãos que apresentam células de multiplicação lenta como cérebro, retina e músculos esqueléticos e cardíacos. A outra forma evolutiva do T.gondii é o oocisto, que é encontrado somente no intestino dos felídeos (Dubey, 1998; Amato Neto et al., 1995). Estas estruturas são excretadas, em sua forma não infectante, nas fezes dos felídeos, sendo que no meio ambiente, em condições favoráveis de temperatura e umidade, esses oocistos irão sofrer um processo de esporulação (esporogonia), tornando-se infectantes e podendo permanecer viáveis por cerca de um ano, desde que a temperatura não ultrapasse $37^{\circ} \mathrm{C}$ (Dubey, 1998; Amato Neto et al., 1995).

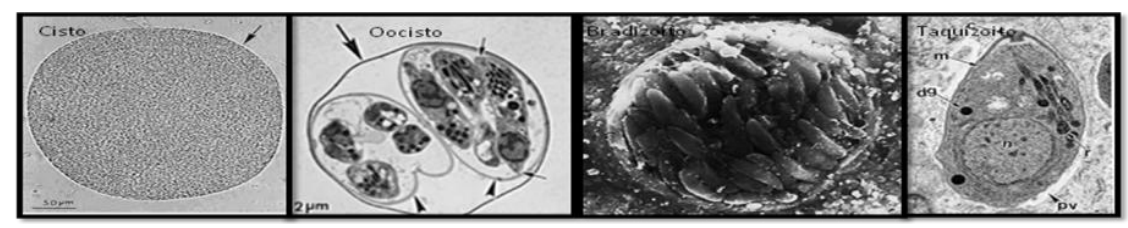

Figura 3 - Formas do T. gondii. 
O gato e outros felinos silvestres, considerados hospedeiros definitivos do $T$. gondii, podem se infectar por meio da caça de outros animais que contenham taquizoítos ou cistos de bradizoítos em seus tecidos, ou pela ingestão de oocistos maduros presentes no solo, e que tenham sido eliminados por outros felinos infectados. Ao alcançar a luz intestinal dos felinos, o parasita penetra nas células pelas vilosidades, sobretudo na região do íleo. No decorrer do processo de multiplicação subseqüente, há o aparecimento de macro e microgametócitos, que irão se unir dando origem aos oocistos, eliminados em grande quantidade nas fezes, após uma a duas semanas da primo-infecção (Dubey, 2003).

O T. gondii apresenta alta infecciosidade e baixa patogenicidade em hospedeiros humanos se for considerada a sua abrangência cosmopolita (Cimerman e Cimerman 1999).

O homem pode adquirir a infecção por meio da ingestão de oocistos do solo, ou presentes em frutas e verduras mal lavadas, ingestão de carne crua ou mal cozida contendo cistos e pela infecção transplacentária (Frenkel, 1988).

Outras formas menos frequentes de adquirir a doença são transfusão sanguínea, transplantes de órgãos e acidentes laboratoriais (Ryning et al., 1979).

Dessa forma, são de grande importância as orientações higiênico-sanitárias sobre como evitar a toxoplasmose, principalmente nos cuidados com gatos, no cozimento adequado de carnes, na ingestão de queijo fresco e leite pasteurizado (Hiratomoto et al., 2002), no tratamento da água e lavagem das frutas e verduras (Remington et al., 1995).

\subsection{Aspectos epidemiológicos}

Provavelmente, a principal fonte de contaminação são os gatos domésticos devido a ampla distribuição da espécie e grande formação de oocistos, uma vez 
que um gato pode excretar milhões de oocistos, após ingerir no mínimo um bradizoíto ou um cisto tecidual, levando há uma grande disseminação ambiental (Dubey e Frenkel, 1972; Dubey, 2001; Hiil e Dubey, 2002). Além disso, alguns trabalhos mostram que a soroprevalência em gatos reflete o grau de disseminação ambiental do agente (Meireles et al., 2004), refletindo a prevalência da infecção em populações locais de aves e roedores.

Apesar da ampla distribuição mundial do T. gondii, as infecções por esse parasita são virtualmente ausentes em ilhotas e atóis que nunca foram habitados por gatos, constatando a importância epidemiológica dos oocistos (Munday, 1972; Wallace, 1969 e Tenter et al., 2000).

Estimam que um terço da população mundial humana já foi infectada, sendo descritas prevalências de $15 \%$ a $85 \%$ na população adulta, variando entre as diferenças populacionais de acordo com o nível sócio econômico (Kijlstra e Jongert, 2008), áreas geográficas e fatores climáticos, hábitos culturais e idade (Tenter et al., 2000).

As taxas de infecção humana são elevadas em vários países latinoamericanos (51-72\%), no Oeste Africano (54-77\%) e na França (85\%). Entretanto, baixas prevalências foram relatadas, em mulher com idade fértil, no Sudeste Asiático, China e Coréia (4-39\%) e em zonas de clima frio, como os países escandinavos (11-28\%) (Tenter et al., 2000). 
Tabela 1 - Prevalência de anticorpos IgG anti - Toxoplasma gondii em indivíduos adultos em vários países.

\begin{tabular}{|c|c|c|c|}
\hline País & $\begin{array}{l}\text { Prevalência } \\
(\%)\end{array}$ & Autor & Ano \\
\hline Brasil & $\begin{array}{l}65,8 \\
50-80 \%\end{array}$ & $\begin{array}{l}\text { Ferreira et al. } \\
\text { Dubey et al. }\end{array}$ & $\begin{array}{l}2009 \\
2012\end{array}$ \\
\hline Sul da África & 20 & Samra et al. & 2007 \\
\hline Índia & 24,3 & Dhume et al. & 2007 \\
\hline Etiópia & 80 & Woldemichael et al. & 1998 \\
\hline Somália & 29,6 & Ahmed et al. & 1988 \\
\hline Sudão & 41,7 & Abdel-Hameed & 1991 \\
\hline $\begin{array}{l}\text { Rep. Dem. São Tomé e } \\
\text { Príncipe }\end{array}$ & 74,5 & Fan et al. & 2007 \\
\hline Àfrica e Àsia & 75 & Leser & 2003 \\
\hline Américas & 70 & Leser & 2003 \\
\hline Europa & $30-60$ & Leser & 2003 \\
\hline Trinidad e Tobago & 43,7 & Adesiyum et al. & 2007 \\
\hline Sul da Europa & 54 & Ajioka, Soldati & 2007 \\
\hline Korea & 6,7 & Shin & 2009 \\
\hline EUA & 15,8 & Ajioka, Soldati & 2007 \\
\hline $\begin{array}{l}\text { População da Colômbia e } \\
\text { Itália }\end{array}$ & 50,8 & Pordeus et al. & 2008 \\
\hline França & 47 & $\begin{array}{l}\text { Fromont, Riche, } \\
\text { Rabiloud }\end{array}$ & 2009 \\
\hline
\end{tabular}

Fonte: Mioranza, 2009. 
No Brasil, a prevalência varia de acordo com a região: Recife (64-79\%) (Coelho et al., 2003), Rio de Janeiro (79\%), Manaus (71\%), São Paulo (68\%), e em indígenas brasileiros (52-65\%) (Amendoeiro et al., 1999).

A prevalência da infecção por $T$. gondii varia de acordo com os hábitos culturais (Kijlstra e Jongert, 2008). Alguns estudos relatam que, nos EUA, a maior parte das infecções nos seres humanos é provavelmente resultado da ingestão de cistos contidos em carne mal cozida. Na França, o hábito da ingestão de produtos cárneos e carne crua ou mal cozida, também interfere na aquisição da infecção em humanos, com 84\% das gestantes apresentando anticorpos contra T. gondii (Hiil et al., 2005).

O maior relato de surto de toxoplasmose humana, no Brasil, ocorreu na cidade de Santa Isabel do Ivaí, Paraná, por veiculação hídrica, a partir da disseminação de oocistos de $T$. gondii em uma estação de tratamento de água (De Moura et al., 2006).

A toxoplasmose adquirida é bastante comum no sul do Brasil (Glasner et al., 1992). Estudos realizados em pacientes, da zona rural do estado do Paraná, mostraram a presença de anticorpos anti-T. gondii da classe IgG em 85,9\% dos indivíduos que se submeteram ao teste de diagnóstico imunofluorescência indireta, e $26,8 \%$ dos indivíduos que apresentaram problemas oculares (Garcia et al., 1995).

Alguns surtos epidêmicos de toxoplasmose humana são relacionadas à ingestão de carne de cordeiro e, neste caso, a exposição destes animais a oocistos de $T$. gondii tem um papel relevante na transmissão do agente em rebanhos destinados ao consumo humano (Teutsch et al., 1979). O T. gondii é responsável por $0,8 \%$ do total de doenças alimentares (Mead et al., 1999), sendo o oocisto a principal fonte de contaminação do solo e água, levando a associação com diversos surtos. 


\subsection{Formas clínicas}

\subsubsection{Toxoplasmose em indivíduos imunocompetente}

Em indivíduos imunocompetentes, a doença é geralmente assintomática, benigna e auto limitada, podendo causar em cerca de $10 \%$ dos casos sintomas como linfadenopatia, meningoencefalite, coriorretinite, pneumonite, miocardite, hepatite, miosite e erupção cutânea (Brown et al, 1991; Amato Neto et al., 1995).

\subsubsection{Toxoplasmose em indivíduos imunodeprimidos}

Pacientes com doenças malignas e submetidos à quimioterapia constituem grupos com formas graves da doença. Nestes indivíduos a doença é febril, com freqüentes sinais e sintomas de envolvimento do sistema nervoso central, má resposta à terapêutica e mortalidade causada pela toxoplasmose (Hakes e Armstrong,1983 e Brown et al.,1991).

O diagnóstico da toxoplasmose em pacientes imunodeprimidos é consideravelmente mais difícil que em pacientes imunocompetentes, uma vez que os anticorpos IgG, em alguns indivíduos, são extremamente comuns, já a presença de anticorpos da classe lgM sugerem infecção aguda, mas não têm sido úteis nos pacientes com AIDS ou câncer para diagnóstico da toxoplasmose em atividade, mesmo porque, tanto em um caso como em outro, parece haver não uma infecção, mas a reativação de parasitas de persistência intracelular em hospedeiros que perderam a capacidade anteriormente existente de limitar a infecção (Pinto et al., 1995). 
Os pacientes transplantados e quimicamente imunodeprimidos compõem outro grupo de indivíduos suscetíveis à toxoplasmose de reativação. Os casos foram descritos após transplantes cardíacos, de medula óssea, e mais raramente de fígado (Anthony, 1972; Krusne et al, 1987) e rim (Reynolds et al, 1966; Meason et al, 1987), talvez pela pequena quantidade de cistos habitualmente existente nesses órgãos. A infecção toxoplasmótica ocorre após transplante cardíaco principalmente em receptores soronegativos que recebem o coração de doador soropositivo, por reativação dos cistos existentes no órgão doado (devido á imussupressão do receptor a fim de evitar a rejeição do órgão), com doença variando desde soroconversão assintomática até miocardite ou doença disseminada (McGregor et al, 1984; Michaels et al., 1992).

\subsubsection{Toxoplasmose congênita}

A toxoplasmose congênita ocorre quando a mãe se infecta durante a gestação e o feto entra em contato com os taquizoítos. Para que haja a infecção do feto, há a necessidade dos taquizoítos circulantes invadirem a placenta. Como o feto ainda não apresenta sistema imunológico e a resposta imune da mãe não consegue atravessar de forma eficiente a barreira placentária, a infecção progride sem controle e de forma devastadora (Andrade et al., 2004; Varella et al., 2003). A toxoplasmose congênita pode causar danos severos como hidrocefalia ou microcefalia, coriorrentinite, estrabismo, calcificações intracranianas e retardamento mental (Sabin, 1948).

O curso da doença congênita depende, principalmente, do período em que se deu a infecção aguda materna. Assim, da sexta à décima sexta semana de gestação, o risco de infecção fetal é menor, porém, se isso ocorrer, haverá um comprometimento grave do feto, caracterizado por processo agudo ou subagudo, 
atacando principalmente o sistema nervoso central da criança, além das manifestações clínicas como a hepatoesplenomegalia, icterícia, linfadenopatia, dentre outras (Andrade et al., 2004). Dessa forma, a infecção intra-uterina pode ser muito grave, acarretando até em abortamento, natimortos, doença neo-natal grave ou prematuridade, além de manifestações tardias (Barder et al., 1997).

Entre as infecções transmissíveis congenitamente, a toxoplasmose ocupa hoje uma posição relevante, uma vez que está aumentando o número de suscetíveis (Barder et al., 1997; Buxton, 1990).

Ocorrendo a existência da toxoplasmose aguda em vigor na gravidez, cabe o tratamento específico, para diminuir o risco de transmissão ao feto e fazer com que o parasita, mais raramente, esteja presente na placenta (Remington et al, 1995).

\subsubsection{Toxoplasmose ocular}

A toxoplasmose ocular pode ocorrer tanto em consequência da transmissão congênita quanto da forma adquirida pós - nascimento, e em ambas, o acometimento ocular pode ser precoce ou tardio, podendo ocorrer clinicamente antes ou, até vários anos depois da infecção sistêmica. As recidivas oculares (cerca de $30 \%$ dos casos) podem ocorrer durante várias décadas, sem mostrar relação com aspectos extra-oculares, incluindo níveis sorológicos (Wilder, 1952).

Na forma congênita clássica, a criança recém-nascida pode apresentar algumas alterações como microencefalia, calcificações cerebrais e retinocoroidite muscular. Trabalhos prospectivos, realizados na Holanda, confirmam que a maior perda das crianças com toxoplasmose congênita não estão associadas as alterações clínicas extra-oculares e as oculares,quando presente, mostram apenas lesões de retinocoroidites periféricas em $37 \%$ dos casos. 


\subsection{Resposta imunológica}

O mecanismo de defesa do hospedeiro exerce um papel importante no controle da atividade do $T$. gondii. Na fase inicial da infecção, ocorre o processo de reconhecimento antigênico e ativação do sistema de defesa específica. A resposta imunológica específica inibe a replicação do $T$. gondii, mas não é capaz de destruílo. Por sua vez o parasita apresenta um mecanismo de escape do sistema imune, assumindo uma forma de baixa imunogenicidade formando cistos em tecidos, os quais se mantêm viáveis por toda a vida do hospedeiro (Lang et al. 2006).

Tabela 2 - Propriedades químicas e biológicas das classes Ig

\begin{tabular}{|l|l|l|l|}
\hline & IgG & IgM & IgA \\
\hline Cadeias pesadas & 150.000 & 160.000 & 900.000 \\
Peso Molecular (dalton) & & 400.000 & \\
\hline Meia vida biológica (dias) & 21 & 5 & 5 \\
\hline Concentração sérica em adultos (mg/dL) & 1000 & 250 & 100 \\
\hline Transferência placentária & + & 0 & 0 \\
\hline Ativação do C via clássica & + & 0 & + \\
\hline Imunidade de mucosa & ++ & + & +++ \\
\hline
\end{tabular}

Modificado de Goldman \& Goldblum, 1977.

O T. gondii induz uma forte resposta humoral, produzindo anticorpos de várias classes como lgM, lgG e lgA, sendo esses anticorpos de grande importância no diagnóstico da doença. Os primeiros anticorpos a serem produzidos são os da classe $\lg \mathrm{A}$, onde aparecem em maiores níveis na infecção recente causada pelo parasita. A IgM permite uma excelente aglutinação, devido sua conformação, onde 
essa imunoglobulina se adere na superfície do parasita, causando um alto nível de citotoxidade, devido a essa característica é muito utilizada para técnicas de diagnósticos sorológicos. Os anticorpos da classe lgG, por serem as únicas imunoglobulinas capazes de atravessar a barreira placentária, são de grande importância para os fetos. A IgA está presente tanto na mucosa como no soro, sendo que essas imunoglobulinas são encontradas em maiores níveis na mucosa (Filisetti e Candolfi, 2004; Jankovic et al., 2001; Szabo et al., 2003).

A principal citocina envolvida na resistência da infecção da toxoplasmose é o IFN- $\gamma$. Sua produção é realizada por células T CD4+ e NK, preferencialmente regulada pela produção de IL-12, sendo esta citocina responsável pelo aumento da capacidade fagocítica contra o T. gondii, que tem um papel importante na indução da conversão de taquizoíto para bradizoíto (Bohne et al., 1993). Já a IL - 10 é uma das citocinas mais importantes envolvidas no controle do efeito Th 1 durante a toxoplasmose aguda (Gaddi e Yap, 2007).

\subsection{Emprego da proteína A em ensaios sorológicos}

A proteína A é composta por uma cadeia polipeptídica com peso molecular em torno de 58 kDa, com interação com a porção Fc da molécula de lgG, na proporção 1:2 .

A proteína $A$ interage com a IgG de várias espécies de mamíferos e também tem afinidade por IgA, IgE e IgM (Lindmark et al., 1983; Johansson e Inganas, 1978; Endrensen, 1979).

Essa interação da proteína A com lgG, anticorpos monoclonais e policlonais, confere uma alta resistência e estabilidade ao complexo formado (Bendayan, 1989). 
A proteína A tem uma interação de afinidade com as imunoglobulinas $\lg G$ e $\operatorname{lgE}$, sendo capaz de se ligar a imunoglobulinas por meio das regiões Fc, interagindo nos domínios $\mathrm{CH}_{2}$ e $\mathrm{CH}_{3}$ (Deisenhofer, 1981; Benjamin et al., 2002). Devido a essa interação, o uso da proteína A vem sendo extensivamente utilizada para técnicas imunoenzimáticas, microscopia eletrônica e imunocitoquímica (Langone, 1982).

A proteína A é isolada de diversas cepas de Staphylococcus e vem sendo uma das proteínas mais estudadas e está localizada na superfície da bactéria, na parede celular do Staphyloccus aureus (Forsgren e Sjoquist, 1966; Verwey, 1940).

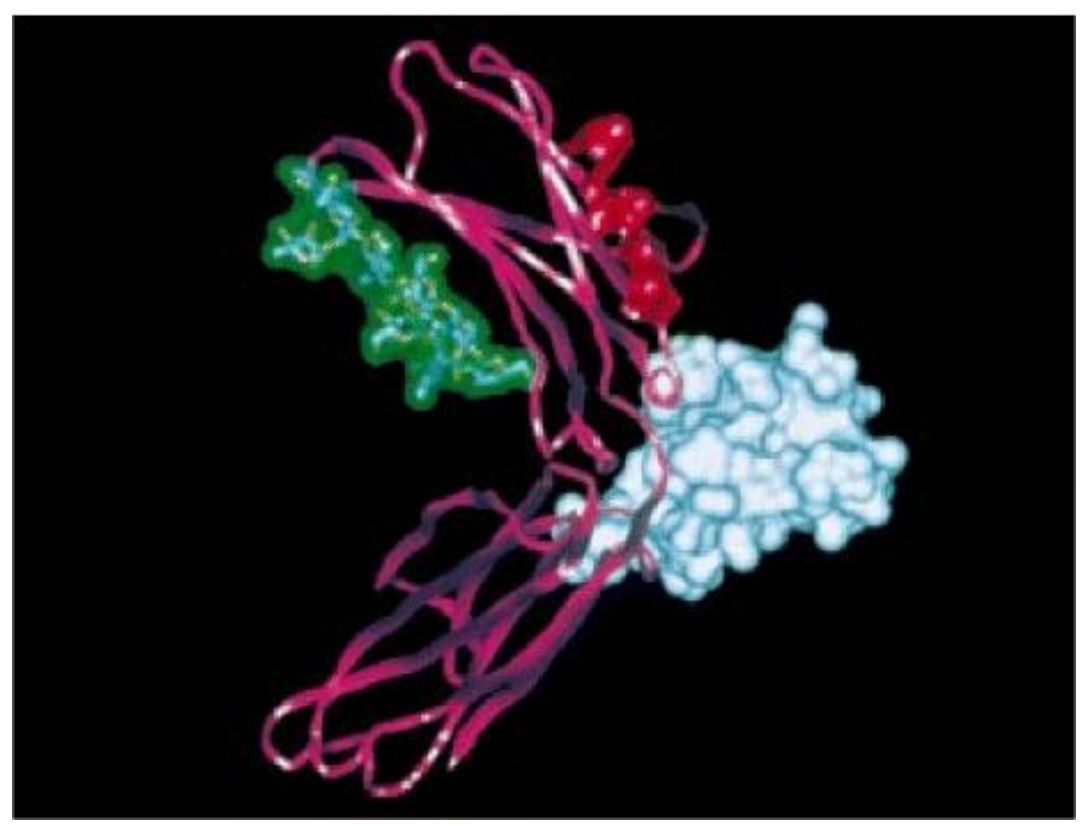

Fonte: Janeway et al., 2001.

Figura 4 - Proteína A de Staphylococcus aureus ligada a um fragmento da região Fc da lgG.

Como pode ser observado na figura 4, a porção Fc, de uma cadeia de $\lg G$ única, é complexada com um fragmento da proteína de ligação de imunoglobulina A, a partir de Staphylococcus aureus. O fragmento Fc tem dois domínios, $\mathrm{CH} 2$ e 
$\mathrm{CH}$, e é mostrado em magenta. Uma cadeia de carboidratos é ligada a um resíduo de asparagina no domínio $\mathrm{CH}_{2}$, Todos os átomos são mostrados e a superfície é descrita em verde. O fragmento de proteína $A$ (branco) é ligado entre os dois domínios do fragmento Fc, já os aminoácidos se ligam ao componente do complemento $\mathrm{C} 1 q$ no domínio $\mathrm{CH}_{2}$ que estão representados em vermelho.

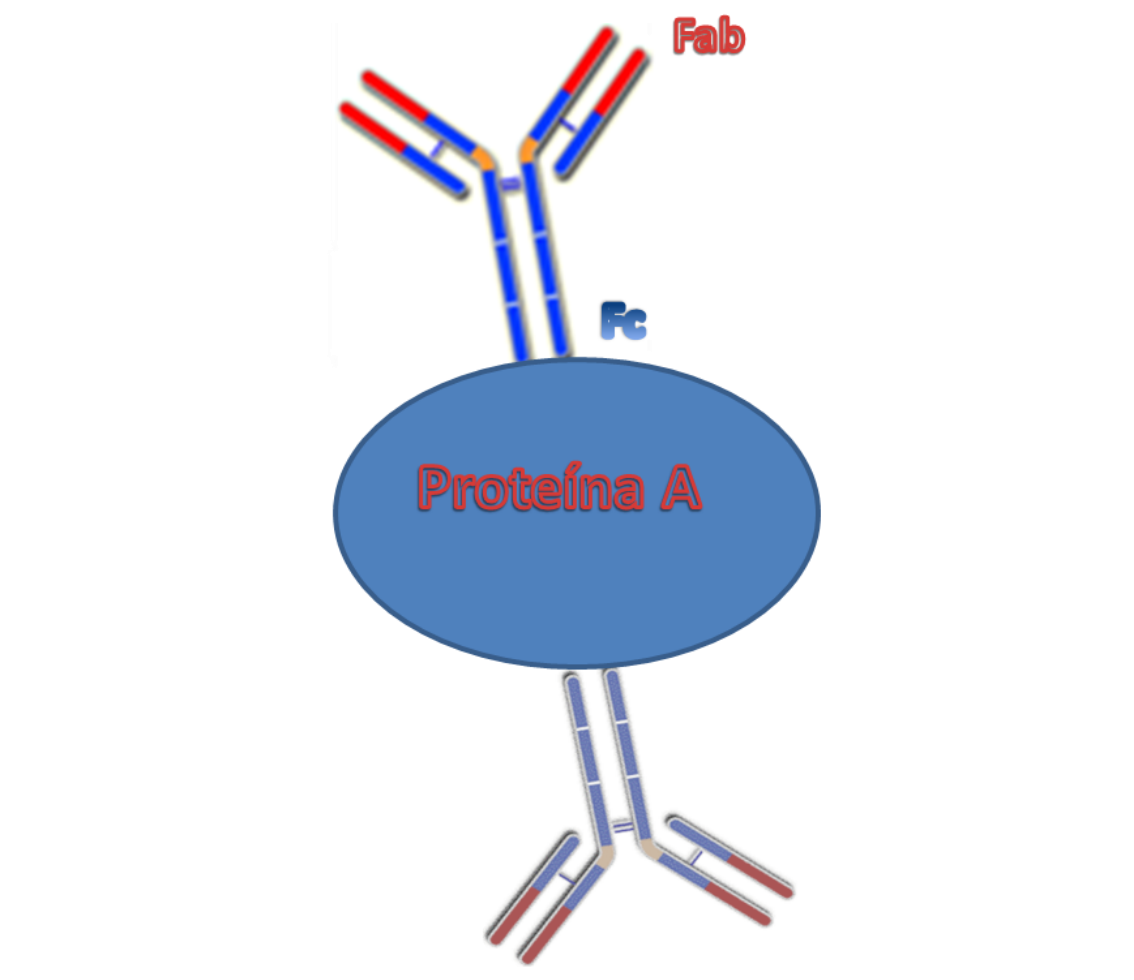

Figura 5 - Proteína A ligada a um fragmento da região Fc de lgG humana.

A proteína A possui uma única cadeia alongada de polipeptídeo, com peso molecular de 42.000, que exibe quatro sítios de ligação para a Fc, como pode ser observada na figura 5 , que mostra a parte $\mathrm{N}$-terminal da molécula está fora da parede celular da bactéria e a porção C-terminal está ancorada (Bjork et al., 1977; Langone et al., 1978).

Uma vez liberada da parede da bactéria, a proteína A possui uma funcionalidade bivalente, sendo capaz de ligar as imunoglobulinas (Langone, 1982). 
O uso da proteína $A$ nos nossos testes foi devido a sua natureza não enzimática e suas propriedades de se ligar as frações Fc da imunoglobulina (Yang et al., 2007; Mioranza, 2009).

\subsection{Diagnóstico laboratorial}

\subsubsection{Detecção de anticorpos anti-T.gondii em soro}

O parasita T.gondii pode ser isolado de componentes orgânicos de diversos tipos, tais como sangue, líquido cefalorraquidiano, saliva e medula óssea, assim como dos conteúdos coletados de infiltrados cutâneos, de manifestações exantemáticas, do baço e especialmente, de gânglios linfáticos (Buxton, 1990).

A principal ferramenta para o diagnóstico da toxoplasmose é a sorologia. Nas últimas décadas, diversas provas sorológicas foram preconizadas para 0 diagnóstico laboratorial da toxoplasmose, tais como:

a) Reação de neutralização: consiste na inoculação intradérmica do parasita, sendo que a presença de anticorpos específicos previne o aparecimento da lesão cutânea (teste positivo). Atualmente, a reação de Neutralização de Sabin não é mais utilizada, por não descriminar toxoplasma-doença de toxoplasmainfecção (Amato Neto et al., 1995);

b) Reação de Sabin - Feldman: ótimo método para diagnóstico da fase aguda ou crônica da doença. É muito sensível e foi um teste muito utilizado por não apresentar reação cruzada com outras doenças. Hoje, esse método está em desuso, pois é necessário trabalhar com o Toxoplasma vivo, aumentando o risco de infecção do manipulador;

c) Reação de fixação do complemento: para sua execução são empregados antígenos diversos, isolados de diferentes materiais como exsudatos peritoneais, 
pulmões ou extrato de fígados de camundongos, ovos embrionados e culturas de tecido. As reações feitas com material obtido de cultura de tecido propiciam bons efeitos, apesar de nem sempre permitirem emprego rotineiro (Veronesi, 2002);

d) Reação de hemaglutinação: fundamentalmente, nessa prova são utilizados lisados de Toxoplasma e hemácias e sensibilizadas. Em presença de soros com anticorpos específicos, esses eritrócitos sofrem aglutinação. Este exame é mais simples do que o teste de Sabin-Feldman e dispensa o uso de parasitas vivos infectantes (Jacob e Lunde, 1957);

e) Reação de imunofluorescência: é um dos métodos mais utilizados, devido à sua segurança e sensibilidade, nas duas fases da doença (aguda e crônica). $\mathrm{O}$ diagnóstico é realizado em lâminas contendo taquizoítos de T.gondii formolizados (Frenkel, 1988);

f) Reação imunoenzimática ELISA (Enzime Linked Immunossorbent Assay): atualmente este teste é o mais empregado devido à alta sensibilidade e à facilidade de automação, sendo empregado para a pesquisa de anticorpos das classes IgM e IgG (Cimerman e Cimerman 1999);

g) Immunoblotting ou western blotting: é usado para identificar proteínas e glicoproteínas específicas, reconhecidas por anticorpos, e envolvidas nos diferentes estágios da infecção, porém não é um teste de rotina (Amato Neto et al., 1995);

h) PCR (Reação em cadeia da polimerase): é um método para detecção de ácidos nucleicos de T.gondii, podendo, inclusive, ser empregado em amostras biológicas que contenham o parasita morto. A PCR apresenta elevada sensibilidade e especificidade, sendo amplamente empregado para detecção do agente em diferentes materiais biológicos como sangue, líquido amniótico, líquor e material de biópsia;

i) dot-ELISA: utiliza membrana de nitrocelulose que adsorve proteínas com grande eficiência, sendo muito útil como fase sólida em ensaios qualitativos, 
quando o volume da amostra é muito pequeno ou com antígenos solubilizados em detergentes iônicos. É um método simples, rápido e de alta sensibilidade, sendo amplamente empregado para detecção de anticorpos específicos e na caracterização de anticorpos monoclonais.

O teste também conhecido como immuno-dot, dot-immunobinding assay, dot-blotting assay, dot-blot ELISA foi desenvolvido por Hawkes et al. (1982) que verificaram que o teste poderia ser aplicado a uma série de antígenos. Os autores obtiveram excelentes resultados com proteínas solúveis e ácidos nucleicos de fungos, bactérias, vírus e protozoários (Ferreira e Ávila, 2001).

Vários trabalhos têm relatado o emprego do dot-ELISA para detecção de anticorpos específicos contra diversos agentes infecciosos devido à alta sensibilidade e especificidade do teste. Estudo recente demonstrou que o dotELISA apresentou alta sensibilidade (100\%) e especificidade (96,6\%) para detecção de anticorpos anti-Leptospira, discriminando muito bem os indivíduos infectados dos não-infectados, com uma eficiência em relação ao MAT de 99,1\% (Blanco, 2007).

O dot-ELISA tem sido descrito como um método diagnóstico eficiente para doenças infecciosas parasitárias como a Leishmaniose tegumentar americana (Walton et al.1986), a esquistossomose (Pinto et al. 1995), a toxoplasmose (Pappas et al., 1986; Angel et al., 1992), a Angiostronsilíase (Eamsobhana et al., 2004) e a erliquiose canina (Machado, 2004).

De acordo com estudos realizados por Pappas e colaboradores (1986), a detecção de anticorpos específicos anti-Toxoplasma por dot-ELISA foi equivalente aos resultados obtidos no ELISA e IFI, sendo que os ensaios variaram em menos de $5 \%$ na detecção de anticorpos IgG e em menos de $3 \%$ na detecção de $\lg M .0$ dot-ELISA apresentou resultados satisfatórios também no diagnóstico da 
toxoplasmose cerebral em pacientes HIV positivos, sendo uma alternativa diagnóstica viável e rápida para o prognóstico da doença (Angel et al., 1992).

Estes estudos têm mostrado que o dot-ELISA é um método sensível, rápido, de baixo custo e de fácil aplicação na rotina laboratorial, permitindo a detecção de anticorpos em pequenas quantidades de amostra. Por estas razões, pretendemos avaliar a eficiência do teste para detecção de anticorpos anti-T.gondii em amostras de saliva.

\subsubsection{Caracterização da saliva}

A saliva é um fluido específico proveniente da secreção das glândulas salivares como a parótida, submandibular, sublingual e glândulas menores, acrescida de substâncias oriundas do fluido crevicular gengival, secreções brônquicas ou nasais, células epiteliais descamadas, restos de alimentos, microorganismos e produtos de seus metabólicos (Kaufman, 2002; Lamster, 2002).

A saliva humana possui diversas propriedades físicas e químicas como alta viscosidade, baixa solubilidade, elasticidade e adesividade, devido às características químicas e estruturais das mucinas, que são glicoproteínas de alto peso molecular, produzidas pelas glândulas sublingual, submandibular e da parótida (Rantonen, 1998; Meurman, 1998).

Existem duas formas de saliva: a saliva da glândulas específicas, que pode ser coletada diretamente das glândulas salivares parótida, submandibular, sublingual e glândulas salivares menores; e a saliva total, sendo esta a mais freqüentemente estudada para a avaliação das doenças sistêmicas (Navazesh, 1993).

As glândulas salivares parótida, submandibular e sublingual, como podem ser observadas na figura 6 , são responsáveis pela produção e secreção de 70 a 
$80 \%$ da saliva, enquanto as glândulas acessórias secretam de 10 a $20 \%$ da saliva (Ten, 2001; Tenovou, 1995).

Ocorre uma grande variabilidade no fluxo salivar, sendo que os valores aceitos como normais estão acima de $0,1 \mathrm{~mL} / \mathrm{min}$ (Humphrey et al., 2001).

Em condições normais, na saliva não são encontrados os linfócitos Tcitotóxicos da imunidade adaptativa. No entanto, são encontrados NK e linfócitos T CD4 e B (Nieuw, 2004).

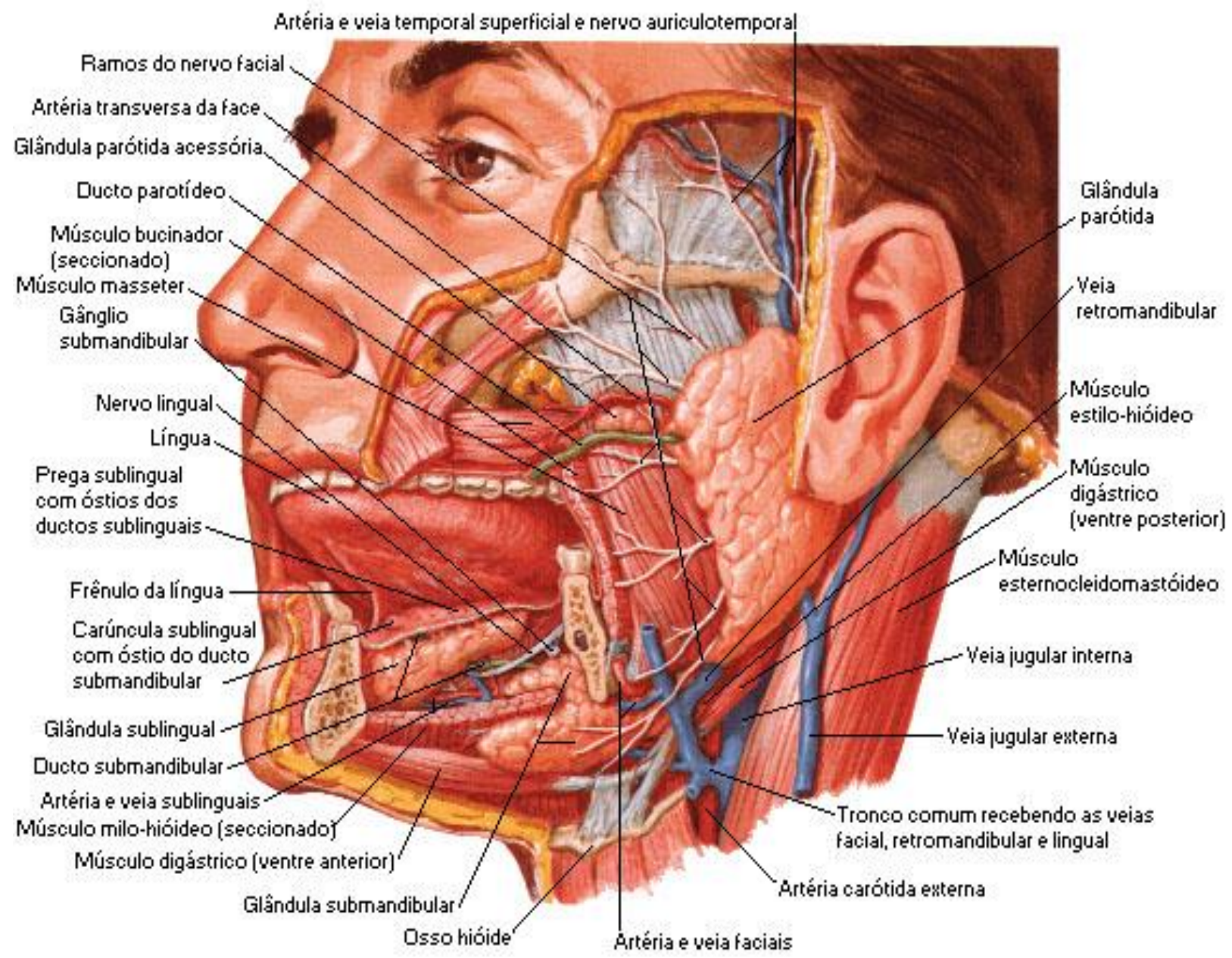

Fonte: NETTER, Frank H., 2000.

Figura 6 - Metade direita da cabeça, seccionada no plano mediano, mostrando as glândulas submandibular e sublingual com seus ductos. 
As imunoglobulinas salivares são capazes de se ligar à maioria dos microorganismos presentes na saliva, apresentando assim, amplo espectro de defesa, o que as difere das imunoglobulinas séricas, que possuem afinidade restrita (Nieuw et al., 2004).

$\lg \mathrm{A}$ e $\lg \mathrm{M}$ são produzidas pelas células plasmáticas que estão situadas no tecido conjuntivo subepitelial ao redor dos ductos intralobulares das glândulas salivares maiores e menores (Takei et al., 1994).

A IgG na saliva pode ser produzida localmente por uma minoria de plasmócitos provenientes do soro ou ainda, chegar à cavidade bucal pelo fluido crevicular por meio do sulco gengival, ou ser derivada do soro por difusão quando ocorre inflamação local ou lesão do tecido epitelial (Gleeson et al., 2000; Lamm,1997; Rantonen, 2003).

Vale ressaltar que, a presença de bactérias, leucócitos, mucina, células epiteliais e restos de alimento podem provocar a degradação da IgG por proteases bacterianas e salivares, podendo, também, dificultar o processamento do material devido à sua viscosidade (Malamud et al., 1997).

A resposta imunológica à infecção pela produção de anticorpos constitui a base de muitos testes diagnósticos. As imunoglobulinas presentes na saliva são oriundas das glândulas salivares e do soro sanguíneo. Há uma predominância de imunoglobulina A secretora, que é derivada de plasmócitos, nas glândulas salivares e representa o principal mecanismo de resposta imune específica da saliva (Nair, 1986; Schhroeder, 1986). Por outro lado, as imunoglobulinas M e G presentes na saliva são derivadas do soro por meio do fluido crevicular gengival e estão presentes em concentração inferior à da IgA salivar (Mortimer, 1988; Parry, 1987).

A saliva pode ser coletada com ou sem estímulo, sendo que estimulada é recolhida por ação de mastigação (o doador mastiga a parafina) ou por estimulação gustativa (a aplicação de ácido cítrico na língua do doador) (Mandel, 1993). 
A estimulação obviamente afeta a quantidade de saliva, porém as concentrações de alguns componentes e do pH do líquido também são afetados, já a saliva não estimulada é coletada sem estimulação exógena gustativa, mastigatórios, ou mecânicos. A taxa de fluxo salivar não estimulado é a mais afetada pelo grau de hidratação, mas também pelo estímulo olfativo, exposição à luz, posição do corpo, e os fatores sazonais e diurnos.

\subsubsection{Detecção de anticorpos anti-T.gondii na saliva}

Os procedimentos laboratoriais mais utilizados para fins de diagnósticos envolvem a análise dos componentes químicos e celulares do sangue, porém outros constituintes biológicos como urina, líquor e fezes são também amplamente empregados na rotina laboratorial. Além disso, vários trabalhos têm avaliado o potencial da saliva como fluido biológico para exames de diagnóstico laboratorial (Moura et al. 2007).

Os diversos componentes salivares não apenas protegem a cavidade bucal, mas, funcionam como biomarcadores de diversas doenças (Lawrence, 002; Wong, 2006; Lauria-Pires, 2008).

Como consequência dos avanços tecnológicos e laboratoriais dos estudos com o fluído oral, a saliva vem deixando de ter aplicações apenas também na detecção de doenças relacionadas à saúde bucal, passando a ser usada como marcadores da saúde geral do indivíduo (Streckfus e Bigler, 2002).

Com esses avanços, o monitoramento e detecção precoce de doenças (Chappin et al., 2007) tem desempenhado papel fundamental no sucesso da terapêutica, podendo diminuir a severidade e complicações da doença. O que dificulta esse monitoramento é a falta de um método fácil, barato, portátil e com conforto na coleta para o paciente. 
A maioria dos estudos epidemiológicos é prejudicada pela difícil coleta invasiva em populações fora do ambiente clínico (Mortimer et al., 1991; Nokes et al., 1997; Billingsley et al., 2006; Dinesh et al., 2008 ). Assim a saliva vem sendo cotada como um método atraente, alternativo e promissor, uma vez que é possível detectar anticorpos para uma variedade de antígenos e a possibilidade do uso em ensaios de larga escala, com pequenos volumes da amostra (Parry, 1993; de Azevedo Neto, et al., 1995; Morris-Cumington et al., 2004a/b; Quoilin et al., 2007).

Paralelamente à utilização de fluidos orais, os testes de diagnósticos rápidos foram fabricados em grande escala nos últimos anos, tornando-se aceitos para o uso no diagnóstico e triagem de doenças infecciosas, e em casos de emergências médicas em locais isolados (Lin et al. 2008; Ponce et al., 2005).

Autoridades de saúde européias recomendam a expansão em pesquisas para o desenvolvimento de testes rápidos, utilizando fluidos biológicos alternativos para o monitoramento e triagem do HIV, entre outras doenças (Pavie et al., 2010) .

A análise de saliva pode fornecer uma abordagem eficaz para a triagem de grandes populações, podendo ser utilizada para a determinação da imunização e detecção de infecção como o sarampo, papeira e rubéola, uma vez que o monitoramento, após a soroconversão, é fundamental para a erradicação de diversas doenças (Friedman, 1982; Perry et al, 1993;. Brown et al, 1994; Cutts et al., 1995; Cutts et al., 1999; Gay et al., 1997).

O fluido oral, no passado, era negligenciado. Hoje, está sendo usado com mais frequência no diagnóstico do HIV, tumores orofacial e sistêmico, doenças cardiovasculares, infecções sistêmicas e detecção de substâncias que causam dependências (Wright et al., 1986; Gorgun et al., 2003, Gordis et al., 2006; Niedbala et al., 2005).

Nos últimos dez anos, o interesse por métodos não invasivos de coleta para diagnóstico vem aumentando a utilização da saliva, tornando-a uma forte candidata 
em teste convencional. Na literatura, constam, aproximadamente, 2.500 artigos desde 1982, descrevendo o uso de saliva e fluido gengival para monitoramento de drogas e detecção de várias doenças bucais, hereditárias e infecciosas (Streckfus e Bigler, 2002).

O Instituto Nacional de Odontologia de Investigação e crânio-facial (NIDCR), desde 2002, explora novas ferramentas de diagnósticos para a utilização de fluidos orais, e vem mostrando o grande potencial da saliva para detecção de doenças, uma vez que este material contém uma abundância de proteínas e moléculas.

A coleta de amostras de saliva possui várias vantagens sobre a punção venosa, já que é conveniente e simples, podendo ser realizada por pessoas não treinadas (como os pais ou monitores locais); é indolor e menos perigosa, tanto para o paciente, como para o manipulador da coleta. Sendo assim, proporciona uma maior aceitação por parte das grandes populações, principalmente de crianças (Vyse et al., 1999).

Existem algumas limitações para o reconhecimento do potencial da saliva como fluido biológico, tais como a falta de biomarcadores definitivos de doenças específicas; a falta de um método fácil e barato de amostragem com o mínimo de conforto; a falta de um método preciso, portátil e de plataforma para facilitar a detecção precoce de doença (Lee e Wong, 2009).

Existem fortes razões para o uso da saliva como fluido diagnóstico, pois corresponde às exigências de criação de métodos de diagnóstico acessíveis, não invasivos e de fácil utilização (Wong, 2006). Como ferramenta clínica, a saliva oferece muitas vantagens em relação ao sangue, incluindo a facilidade de coleta, o baixo custo e o conforto ao paciente (principalmente crianças). Ainda existe a vantagem de ser um material de fácil manuseio nos procedimentos diagnósticos, 
uma vez que não coagula, diminuindo assim as manipulações necessárias (Wong, 2006).

A utilização da saliva como material biológico foi inicialmente empregado para o monitoramento de drogas e hormônios (Haeckel, 1989), sendo, em seguida, aplicada no diagnóstico de doenças infecciosas de diferentes origens como fúngicas (Jeganathan et al., 1987), bacterianas (Granstrom et al., 1988) e parasitárias, tais como esquistossomose (Garcia et al. , 1995; Wang et al., 2002) e neurocisticercose (Feldman et al., 1990) e infecções virais (Parry et al., 1987; Archibald et al., 1987; Perry et al., 1993).

A saliva pode ser utilizada como uma fonte para detecção de IgM contra rubéola, com uma especificidade de $96 \%$, quando comparada ao padrão ideal do teste no soro sanguíneo (Vyse et al. 1999 e Oliveira et al. 2000).

Na toxoplasmose, o estudo pioneiro de utilização da saliva para pesquisa de anticorpos foi realizado por Hajeer e colaboradores (1994), que demonstraram a eficiência deste fluido biológico na detecção de anticorpos $\lg A, \lg M$ e $\lg G$, em comparação com os resultados obtidos com amostras de soro testadas por aglutinação direta e immunoblot.

Para investigar o potencial uso da saliva para detecção de anticorpos contra Toxoplasma gondii, Loyola e colaboradores (1997) realizaram estudos epidemiológicos e de vigilância da toxoplasmose, demonstrando a aplicabilidade da detecção de anticorpos IgA na saliva como marcadores de toxoplasmose aguda em ensaios de ELISA.

Stroehle e colaboradores (2005) desenvolveram um ensaio de immunoblot para detecção da presença de lgG anti-T.gondii em 201 amostras de salivas, demonstrando que este ensaio poderia ser um método alternativo de alta especificidade para triagem laboratorial da toxoplasmose. Além disso, os resultados foram semelhantes aos descritos anteriormente para a detecção de $\lg G$ específico 
para rubéola e vírus da imunodeficiência humana tipo I (Granade et al., 1995) e para o imunodiagnóstico da infecção por Schistosoma mansoni (Santos et al., 2000), demonstrando a importância da saliva como uma fonte de anticorpos para testes laboratoriais.

A importância da saliva, como material biológico e de coleta não invasiva para o diagnóstico e estudo da prevalência da toxoplasmose em crianças em idade escolar, foi demonstrada também por Macre e colaboradores (2008). A saliva foi submetida ao tratamento com etanol absoluto para concentração das imunoglobulinas da classe $\lg$ e as amostras foram analisadas por ELISA, frente a extratos totais de T.gondii, mostrando uma boa sensibilidade e especificidade, quando comparadas com as respectivas amostras de soro.

A aplicação da saliva, como material biológico para diagnóstico da toxoplasmose, tem sido avaliada por meio de ensaios imunoenzimáticos como ELISA e immunoblot, porém não há relatos na literatura do uso do dot-ELISA, que é um teste rápido e de alta sensibilidade, para estudos de triagem da toxoplasmose como é feito para outras doenças infecciosas.

\subsection{Prevenção e tratamento}

Trabalhos educativos com toda a população no sentido de ressaltar a importância do consumo de carne e derivados bem cozidos, assim como instruções para remoção cuidadosa das fezes dos animais, como desinfecção do local, onde foram depositadas. Cozimento dos alimentos por pelo menos $60^{\circ} \mathrm{C}$ por 20 minutos, visando a garantia de que o calor penetre igualmente no alimento seriam algumas formas primárias de eficazes de profilaxia da doença (Dubey, 1991; Dubey et al., 1972; Sparkes, 1998). No caso de doença em indivíduos imunodeprimidos, a toxoplasmose se reveste de características de maior gravidade. Nesses pacientes, 
os testes de diagnósticos não são fidedignos e raramente mostram lgM na fase aguda da enfermidade e alguns adquirem doença grave com sorologia totalmente negativa. Nessa população, a profilaxia é de vital importância, havendo tempo útil para tanto. O mesmo é válido para os casos de transplantes, em que a toxoplasmose pode ser fatal (Amato Neto et al., 1995).

A grande indicação da prevenção da toxoplasmose inegavelmente se refere à forma congênita, na qual o risco se correlaciona à forma aguda da doença na mãe. A tática mais recomendada é a sorologia pré-natal, se a mulher for negativa, acompanhamento sorológico a cada trimestre da gestação, aliado a profilaxia primária. Se houver evidência de infecção pelo toxoplasma na gravidez, o tratamento da mãe é crucial (Castro et al., 2001).

Como tudo em saúde pública, quando o assunto é diagnóstico, análises claras da relação custo/benefício, conforme as condições socioeconômicas do país, são fundamentais. Assim, o diagnóstico da toxoplasmose pode ser feito com testes relativamente baratos, mas com certeza, hoje, pode compreender técnicas tão caras como o PCR no soro fetal (Botterel et al., 2002). Assim, tanto os inquéritos sorológicos, quanto às condutas de tratamento são justificáveis e economicamente viáveis, trazendo grandes benefícios à sociedade, evitando, por meio da prevenção, um grande contingente de crianças com deficiência mental e coriorretinite nas populações (Roberts et al., 1999).

Ainda não foram desenvolvidas vacinas seguras e com eficácia contra a toxoplasmose humana que previnam a infecção congênita ou reativação de cistos. Consequentemente, a melhor maneira de se evitar os efeitos da doença é através de sua prevenção (Jones et al., 2001).

Entretanto, no Instituto de Medicina Tropical da Universidade de São Paulo, pesquisas estão sendo realizadas para desenvolver uma vacina com taquizoítos irradiados, podendo ser utilizadas em iscas para dar aos felídeos, realizando a 
imunização desses animais, uma vez que ao cortar o ciclo sexuado da doença nos felídeos, diminui-se o número de contaminação em humanos (Galisteo Jr., 2008).

Alguns obstáculos têm contribuído para a falta de orientação terapêutica mais taxativa em relação à toxoplasmose, entre eles: a) a disponibilidade de acervo não muito elevado de informações sobre casos agudos submetidos a bem programadas pesquisas com drogas; b) o estabelecimento de diagnóstico geralmente tardio, quando lesões avançadas ou definitivas já estão instaladas, o que pode ser ilustrado pelas alterações acentuadas presentes em paciente com toxoplasmose congênita; c) a severidade variável dos quadros clínicos ligados à protozoose, existindo em certas ocasiões cura clínica até mesmo espontânea, o que impede a realização de interpretações mais precisas; d) a existência de publicações médicas que apresentam conclusões de ordem terapêutica baseadas no seguimento de casos cujo diagnóstico pode ser considerado criticável (Rey, 1991).

No entanto, existem evidências da eficácia do tratamento da toxoplasmose. Além de resultados experimentais favoráveis, devemos citar aqui a boa efetividade demonstrada no tratamento de pacientes imunodeprimidos, da coriorretinite de forma severa (por exemplo, cardíacas e pulmonares), bem como na redução da patogenicidade da forma congênita (em especial das subclínicas) e na diminuição da frequência da transmissão da infecção ao feto e da gravidade desta, quando são tratadas precocemente as gestantes com doença aguda (Amato Neto et al., 1995).

Nos últimos anos, em virtude da importância da toxoplasmose como infecção oportunista na síndrome da imunodeficiência adquirida, a procura de novos medicamentos eficientes no combate a esta protozoose ganhou novo 
impulso, e já estão disponíveis alguns resultados interessantes como veremos mais adiante (Cirmerman e Cimerman, 1999).

Uma série de novos medicamentos tem sido testada nos últimos anos como antagonistas do ácido fólico (piretrexina e trimetrexato), análogos purínicos (arprinocid), novos macrolídicos (roxitromicina, azitromicina, claritromicina) e imunomoduladores (interferon, interleucina) (Jones et al.,2001).

O ácido folínico é empregado com frequência para profilaxia dos distúrbios hematológicos que podem decorrer do uso da associação pirimetaminasulfadiazina. É utilizado pela via oral, em doses diárias de 2 a 10 miligramas, conforme a idade e o peso do paciente (Amato Neto et al., 1995).

Quanto ao tempo de duração do tratamento da toxoplasmose, não existem regras rígidas nem estudos conclusivos quanto aos períodos ideais. Em geral, são preconizadas três a seis semanas de medicação. Em alguns casos, estes esquemas terão que ser modificados, ou aumentando-se a duração ou repetindo-se mais de uma série terapêutica, ou mantendo-se doses menores por tempo indefinido para a prevenção de recídivas (Cimerman e Cimerman, 1999).

Ainda não existe uma droga eficaz contra a toxoplasmose na fase crônica da infecção. Os medicamentos utilizados atuam contra as formas proliferativas, mas não contra os cistos. Como a grande maioria das pessoas que tem sorologia positiva não tem doença, e como as drogas empregadas são tóxicas em dosagens prolongadas, recomenda-se tratar apenas os casos agudos (Cimerman e Cimerman, 1999). 


\section{JUSTIFICATIVA}

A detecção de anticorpos é a principal ferramenta no diagnóstico da toxoplasmose, porém os métodos disponíveis estão voltados para a pesquisa de anticorpos em amostras de soro, com poucos relatos sobre a utilização de material biológico de outra natureza, como a saliva. Como ferramenta clínica, a saliva oferece muitas vantagens relativamente ao sangue, incluindo a facilidade de coleta, o baixo custo e o conforto ao paciente (principalmente crianças). Ainda existe a vantagem de ser um material de fácil manuseio nos procedimentos diagnósticos, uma vez que não coagula, diminuindo assim as manipulações necessárias.

Vários trabalhos têm relatado o emprego do dot-ELISA para detecção de anticorpos específicos contra diversos agentes infecciosos em amostras de saliva devido à alta sensibilidade, especificidade e praticidade do teste. Além disso, o dotELISA permite a detecção de anticorpos em pequenas quantidades de amostra, e a utilização da proteína A garante a especificidade do teste, mostrando a possibilidade de um exame rápido de triagem. A otimização dos ensaios sorológicos vem ressaltar o potencial da saliva como material biológico para a pesquisa de anticorpos anti- T. gondii.

A detecção de anticorpos específicos lgG no soro tem inúmeras utilidades médicas, quer seja na detecção de contato com agentes infecciosos, como na toxoplasmose humana, ou demonstração de eficiência vacinal. Normalmente, os estudos sorológicos têm utilizado a coleta de sangue, através de punção clássica por agulha com produção de soro ou coletas de sangue total com lanceta em papel filtro. Os dois materiais, com diferentes graus de pureza, são fontes de $\lg G$ específica, detectadas por testes de diferentes sensibilidades e especificidades, como a imunofluorescência indireta e ELISA, no caso da toxoplasmose humana. 
Recentemente, procuramos detectar o contato com a toxoplasmose em crianças, um grupo altamente protegido da sociedade, com consequente dificuldade para a coleta invasiva de sangue. Nossa alternativa foi o uso de saliva, que tem IgG secretada ou do líquido crevicular, por meio de coleta simples, seguida de concentração e ELISA, o que permitiu a detecção de lgG específica contra o agente em escolares, mas com ressalvas pela variação do conteúdo de $\lg G$ em cada amostra de saliva. As técnicas utilizadas necessitam da concentração da saliva e um grande volume de saliva inicial $(5 \mathrm{ml})$. Novas técnicas de imunofluorimetria, micrométodos ou de aprimoramento de sistemas de detecção em ELISA têm sido desenvolvidas e o uso delas pode resultar em aprimoramento destes ensaios, permitindo a detecção em saliva sem concentração, ou em pequenos volumes. Neste trabalho, desenvolvemos métodos de maior eficiência e sensibilidade na detecção de $\lg$ específica contra o T.gondii, padronizando técnicas de alta sensibilidade em saliva de voluntários, com controle de quantidade de $\lg G$, no estudo da toxoplasmose humana. 


\section{OBJETIVOS}

\section{Geral}

Desenvolvimento de ensaios imunoenzimáticos para otimização da detecção de IgG específica em saliva humana.

\section{Específicos}

a) Dosagem de proteína total da saliva por Dosagem de Bradford;

b) Dosagem de anticorpos IgG anti- T. gondii por ELISA;

c) Dosagem de anticorpos específicos IgG anti- T. gondii por dot-ELISA;

d) Avaliar diferentes preparações de saliva para ensaio nos testes imunoenzimáticos ELISA e dot-ELISA tais como: saliva pura, saliva precipitada com etanol e saliva diluída após precipitação com etanol;

e) Padronização da técnica ELISA, utilizando proteína A para captura e detecção de lgG anti - T. gondii em saliva;

f) Padronização do dot-ELISA, utilizando proteína A para captura e detecção de $\lg G$ anti - T. gondii em saliva. 


\section{MATERIAL E MÉTODOS}

\subsection{População estudada}

As salivas foram coletadas de 120 voluntários (20 amostras piloto e 100 amostras para aplicação) que participaram do processo de acordo com o termo de consentimento livre esclarecido, devidamente assinado pelos responsáveis no caso de menores de idades (Consentimento no Anexo I). Os participantes eram alunos do curso de graduação de Turismo da Escola de Comunicações e Artes (ECA) da Universidade de São Paulo, do curso de graduação de Medicina da Faculdade de Medicina da Universidade de São Paulo e alunos de pós-graduação do Laboratório de Protozoologia do Instituto de Medicina Tropical de São Paulo - USP.

\subsection{Organização e elaboração do "kit coleta de saliva"}

A organização e a elaboração do kit coleta de saliva têm como objetivo facilitar a intervenção e entrega do material didático para maior compreensão dos voluntários participantes.

Focalizando o objetivo do projeto, o material didático (anexos E e F) ilustra melhor o tema e desmistifica a doença toxoplasmose, justificando o uso da coleta de saliva e a importância da pesquisa. 


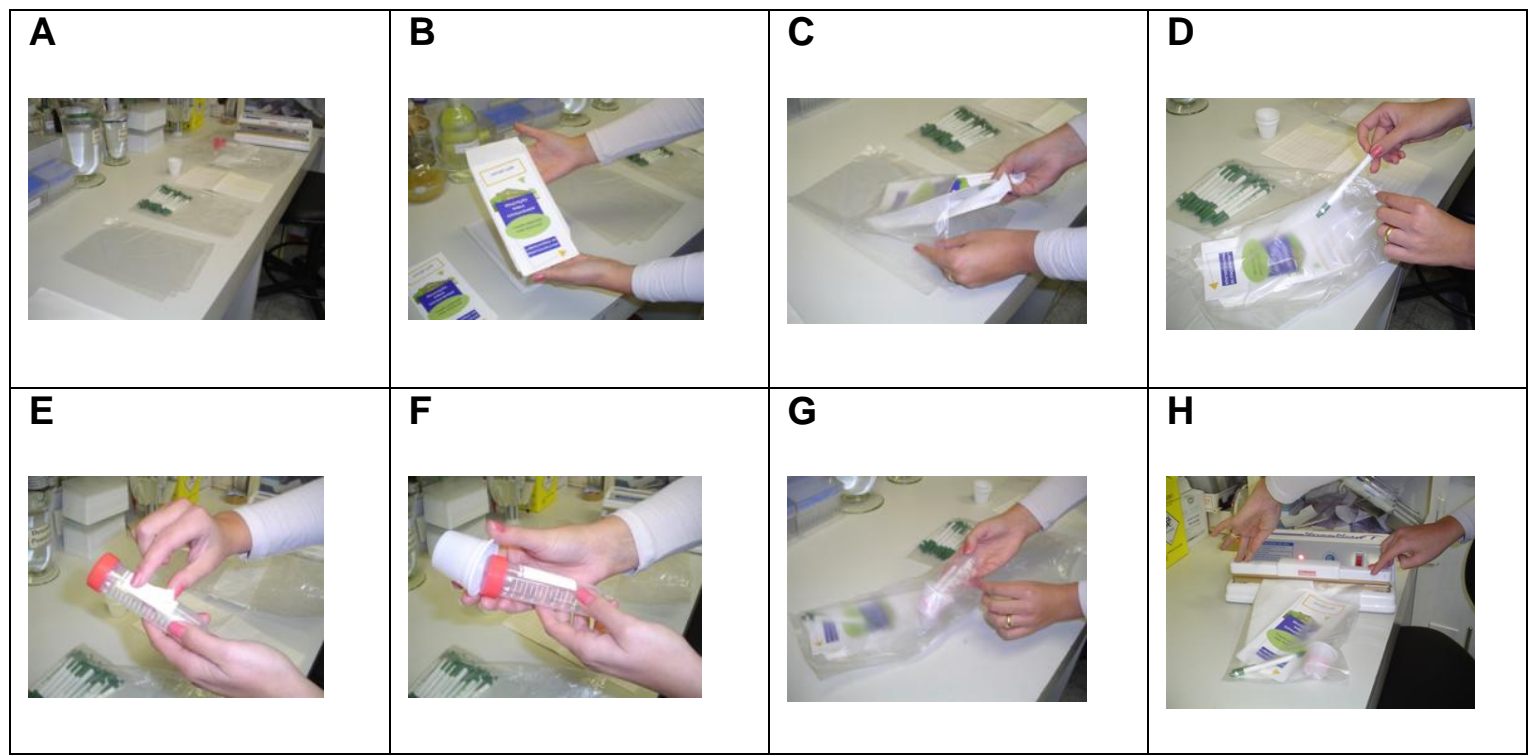

Figura 7 - Fotos da confecção do kit-coleta de saliva.

O kit de coleta era composto por um tubo falcon estéril de $45 \mathrm{~mL}$, um copo descartável para utilização do enxaguante bucal, uma caneta para identificação do tubo e folheto educativo. $O$ folheto educativo foi elaborado pela equipe do Laboratório de Protozoologia do Instituto de Medicina Tropical de São Paulo, para ser utilizado quando necessário para ilustração das intervenções, sendo o veículo de instrução simplificado ao alcance de todos. O conteúdo foi abordado resumidamente, com ilustrações didáticas e esclarecedoras. O folheto continha informações curtas e concretas, ilustrando o valor e a importância do tema.

\subsection{Coleta das amostras de saliva}

Para a intervenção da coleta de saliva utilizamos o que denominamos "kit coleta de saliva", para ser entregue a cada voluntário.

Após a intervenção na sala e a entrega do termo de consentimento livre esclarecido, os alunos autorizados eram conduzidos para a coleta da saliva sob a 
supervisão de professores e pesquisadores. Era realizada a higiene da cavidade oral, com uso de $25-40 \mathrm{ml}$ de enxaguante oral (Listerine $\left.{ }^{\circledR}\right)$, de uso comercial, bochechos e 03 lavagens da cavidade com água potável sem aditivos. Sem qualquer outro estimulo, foi solicitado para que os alunos completassem com saliva até a marca de 05 ou mais $\mathrm{ml}$ do tubo de coleta, na dependência da produção individual de cada um. Nenhum aluno foi convidado a coletar mais saliva do que o necessário para o teste. Após a intervenção, os tubos coletados contendo a saliva eram colocados em banho de gelo para evitar perdas e mantidos assim até seu transporte e processamento no Laboratório de Protozoologia, no mesmo dia.

Foram coletadas 120 amostras de saliva, para posteriormente serem testadas pelas técnicas de ELISA e dot - ELISA.

\subsection{Parasitas}

Suspensões de taquizoítos da cepa $\mathrm{RH}$ de $T$. gondii foram mantidas no Laboratório de Protozoologia do Instituto de Medicina Tropical de São Paulo, por meio de sucessivas passagens com intervalos de 3 a 4 dias, em camundongos Swiss não isogênicos, pesando em torno de $20 \mathrm{~g}$, e com idade variando entre $30 \mathrm{e}$ 60 dias. Os animais previamente infectados foram submetidos à eutanásia por narcose em câmera de $\mathrm{CO}_{2}$ e o peritônio lavado com $5 \mathrm{ml}$ de solução salina tamponada com fosfato $0,01 \mathrm{M} \mathrm{pH} \mathrm{7,2} \mathrm{(PBS)} \mathrm{estéril} \mathrm{contendo} \mathrm{Penicilina} \mathrm{Cristalina}$ $2500 \mathrm{Ul} / \mathrm{ml}$ e Estreptomicina $10 \mathrm{mg} / \mathrm{ml}$. Após quantificação em câmara de Neubauer, os parasitas foram diluídos apropriadamente em PBS, e cada animal recebeu $10^{7}$ taquizoítos por inóculo intraperitoneal. 


\subsection{Extratos antigênicos de T.gondii}

\subsubsection{Antígeno salino}

O extrato antigênico salino foi obtido por aprimoramento da metodologia descrita na literatura (Camargo et al., 1978). Para obtenção de antígeno protéico solúvel de $T$. gondii foram utilizados $3 \times 10^{8}$ taquizoítos da cepa $\mathrm{RH}$. A suspensão parasitária obtida através do lavado peritoneal de animais infectados, como descrito no item 4.2, foi purificada por filtração em membrana de policarbonato $5 \mu \mathrm{m}$ (Millipore $^{\circledR}$ ) e centrifugada a $700 \mathrm{~g}$ por 10 minutos a $4^{\circ} \mathrm{C}$. O precipitado suspenso em $5 \mathrm{ml}$ de água destilada foi submetido à sonicação $(0.40 \mathrm{MHz}, 4 \mathrm{Vdc})$ por 4 períodos de 30 segundos, em banho de gelo via sonicador de ponta Thornton ${ }^{\circledR}$. Após certificação microscópica da lise total dos taquizoítos, foi acrescentado $5 \mathrm{ml}$ de solução de $\mathrm{NaCl} 0,3 \mathrm{M}$ e a suspensão foi centrifugada a $10.000 \mathrm{~g}$ a $4^{\circ} \mathrm{C}$ por 30 minutos, em centrífuga refrigerada Eppendorf 5403. O sobrenadante foi separadas em alíquotas e mantido à $-70^{\circ} \mathrm{C}$ até o momento de seu uso. Todas as reações foram realizadas com uma mesma partida de antígeno.

\subsubsection{Antígeno biotinilado para ensaio de captura de IgG por proteína A}

Para o ensaio de captura de anticorpo por Proteína A ligada a suporte sólido havia a necessidade de produção de um antígeno conjugado direta ou indiretamente a peroxidase. Optamos pelo processo de biotinilação e revelação por avidina peroxidase. O extrato antigênico salino obtido no item 4.5.1 foi estabilizado em tampão por cromatografia em gel de exclusão molecular BioGel P2 em sistema de cromatografia líquida ÄKTA (Amersham Biosciences). Uma vez estabilizado em tampão neutro livre de aminas $\left(\mathrm{Na}_{2} \mathrm{PO}_{4} 83 \mathrm{mM}\right.$; $\mathrm{NaCl} 900 \mathrm{mM}$ e EDTA $100 \mathrm{Mm}$ 
$\mathrm{pH} 7,5)$, a fração de alto peso molecular do extrato foi adicionada de $1 \mathrm{mg}$ de Hidroxisuccinimida de ácido biotinamidohexanóico(BAC Biotin Sigma Cat $n^{\circ}$ B2643) com elevação do pH para 8.0 com adição de Bicarbonato de Sódio 10\%. A ligação foi obtida por incubação por 1 hora a temperatura ambiente, sendo finalmente adicionada glicina $0.1 \mathrm{M} \mathrm{pH} \mathrm{8,0} \mathrm{para} \mathrm{reagir} \mathrm{com} \mathrm{eventual} \mathrm{biotinas} \mathrm{livres.} \mathrm{Esta}$ mistura foi novamente submetida a cromatografia em BioGel p-2 para retirada de componentes de baixo peso molecular e biotinas livres. O extrato antigênico biotinilado teve seu conteúdo protéico quantificado pela técnica de Bradford, sendo estocado a $-20^{\circ} \mathrm{C}$ em alíquotas prontas para uso.

\subsection{Dosagem protéica}

As dosagens protéicas dos diferentes preparados antigênicos foram efetuadas empregando-se o método de Bradford (1976).

\subsection{Ensaios imunoenzimáticos}

\subsubsection{ELISA (Enzyme-Linked Immunosorbent Assay)}

A técnica foi desenvolvida de acordo com a metodologia descrita por Venkatesan e Walklin (1993). Placas de poliestireno de 96 poços para microtitulação $\left(\right.$ Costar $\left.^{\circledR}\right)$ foram sensibilizadas com $100 \mu \mathrm{l} /$ poço com proteínas de $T$. gondii (extrato antigênico solúvel), suspensas em tampão carbonato de sódio $0,1 \mathrm{M}$ pH 9.5, na concentração de $10 \mu \mathrm{g} / \mathrm{ml}$ de antígeno. Após sensibilização por 20 horas à $4^{0} \mathrm{C}$, em câmara úmida, as placas foram lavadas três vezes, por 5 minutos cada, com PBS 0,01M pH 7.2, contendo 0,02\% de Tween 20 (PBST) e bloqueadas com 
$3 \%$ de solução de leite desnatado $\left(\right.$ Molico $^{\circledR}$ ) em PBST durante 1 hora em estufa a $37^{0} \mathrm{C}$

Após bloqueio, as placas foram novamente lavadas três vezes e as

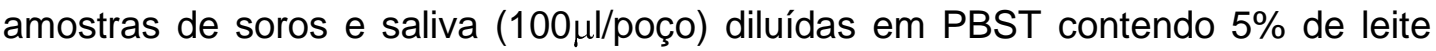
desnatado foram depositadas nas placas e incubadas a $37^{\circ} \mathrm{C}$ por 1 hora. Após três novas lavagens, foram aplicados $100 \mu \mathrm{l}$ por cavidade de conjugado imunoenzimático marcado com peroxidase e a placa novamente incubada por 1 hora a $37^{\circ} \mathrm{C}$.

Após lavagem, a revelação da reação foi feita pela adição de solução citrato de sódio 0,05M pH 5.8, contendo OPD $0,4 \mathrm{mg} / \mathrm{ml}$ e $\mathrm{H}_{2} \mathrm{O}_{2}$ 0,03\% e interrompida, após 30 minutos, pela adição de $\mathrm{HCl}$ 4N. A leitura das densidades ópticas (D.O.) foi realizada em leitor automático de microplacas (Labsystems Multiskan MS) a 492 $\mathrm{nm}$.

\subsubsection{ELISA de captura}

A técnica foi desenvolvida com a metodologia descrita por Carvalho et al., 2008, com modificações realizadas para o aprimoramento e padronização da nossa técnica de captura. Placas de poliestireno de 96 poços para microtitulação (Costar®) foram sensibilizadas com $100 \mu \mathrm{l} /$ poço com proteína $A$, suspensas em tampão carbonato de sódio $0,1 \mathrm{M} \mathrm{pH} \mathrm{9.5,} \mathrm{na} \mathrm{concentração} \mathrm{de} 10 \mu \mathrm{g} / \mathrm{ml}$ de Proteína A. Após sensibilização por 20 horas à $4^{\circ} \mathrm{C}$, em câmara úmida, as placas foram

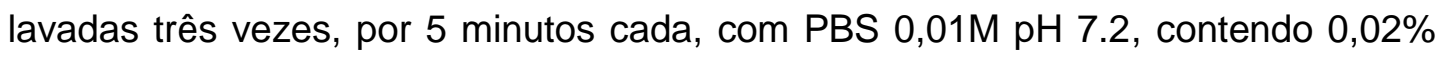
de Tween 20 (PBST) e bloqueadas com 3\% de solução de leite desnatado (Molico®) em PBST durante 1 hora em estufa a $37^{\circ} \mathrm{C}$. 
Após bloqueio, as placas foram novamente lavadas três vezes e as

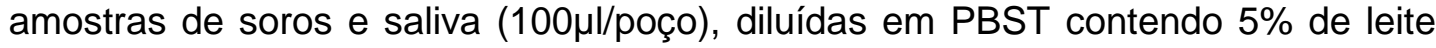
desnatado, foram depositadas nas placas e incubadas a $37^{\circ} \mathrm{C}$ por 1 hora. Após 3 novas lavagens, foram aplicados $100 \mu \mathrm{l}$ por cavidade do antígeno de T. gondii Biotinilado e a placa foi novamente incubada por 1 hora a $37^{\circ} \mathrm{C}$.

Após lavagem, foram aplicados $100 \mu$ por cavidade do complexo avidinaperoxidase e a placa foi novamente incubada por 1 hora a $37^{\circ} \mathrm{C}$.

Após lavagem, as reações foram reveladas com diferentes cromógenos como, OPD e TMB, sendo utilizada para cada revelador uma solução de bloqueio específica. A reação revelada por OPD recebeu à adição de solução citrato de sódio 0,05M pH 5.8 e H2O2 0,03\% e foi interrompida, após 30 minutos, pela adição de $\mathrm{HCl} 4 \mathrm{~N}$. A leitura das densidades ópticas (D.O.) foi feita em leitor automático de microplacas (Labsystems Multiskan MS) a $492 \mathrm{~nm}$. Para o TMB foi utilizado ácido sulfúrico (1M) para bloqueio da reação e a leitura na D.O. foi feita a $450 \mathrm{~nm}$.

\subsection{3 dot-ELISA}

A técnica de dot - ELISA foi executada segundo a metodologia descrita por Hawkes et al., (1982), com modificações realizadas pelo Laboratório de Protozoologia do Instituto de Medicina Tropical - USP. Brevemente, membrana de nitrocelulose $\left(\operatorname{BioRad}^{\circledR}\right)$, foram sensibilizadas com $50 \mu \mathrm{l} /$ poço com antígeno solúvel de $T$. gondii , suspensos em tampão 0,1M carbonato-bicarbonato de sódio pH 9,5 nas concentrações de $0,5 \mu \mathrm{g} / \mathrm{mL}$ para triagem de amostras de soro e $1,5 \mu \mathrm{g} / \mathrm{mL}$ de antígeno para amostras de saliva, utilizando-se um sistema dot blot de 96 poços $\left(\right.$ BioRad $\left.^{\circledR}\right)$.Após sensibilização, as membranas foram retiradas do sistema dot blot, cortadas em tiras de aproximadamente $0,4 \mathrm{~mm}$ e colocadas em bandejas de 
incubação com canaletas de $10,5 \mathrm{~cm} \times 5 \mathrm{~mm}\left(\right.$ BioRad $\left.^{\circledR}\right)$, onde foram bloqueadas com PBSTL 5\%, por 5\%, por 2 horas em temperatura ambiente. Em seguida, as membranas foram lavadas 3 vezes por 5 minutos com PBST 0,05\% sob agitação. Em seguida, foram aplicados volumes de $500 \mu \mathrm{L} /$ canaleta de amostras de soro ou saliva, com incubação por 1 hora, sob agitação em temperatura ambiente. Após a incubação, as membranas foram novamente lavadas 3 vezes e foram aplicados $500 \mu \mathrm{L} /$ canaleta do conjugado anti - IgG humano na diluição de $1 / 10.000$, sendo as amostras incubadas por 1 hora em temperatura ambiente. Decorrido o tempo de incubação, as membranas foram novamente lavadas 3 vezes. A reação foi revelada utilizando-se como cromógeno o 3,3 - Diaminobenzidina (DAB), sendo aplicados $500 \mu \mathrm{L} /$ canaleta da solução cromógena $(10 \mu \mathrm{g}$ DAB, acrescido de $10 \mathrm{~mL}$ PBS e $15 \mu \mathrm{L}$ de água oxigenada 30\%).

\subsubsection{Determinação da concentração $(\mu \mathrm{g} / \mathrm{mL})$ de $\lg G$ anti-T.gondii}

Para determinação da concentração de lgG anti-T.gondii, a partir dos dados de cada placa, foi utilizada uma planilha criada no programa Excel, onde as densidades ópticas (DO) das concentrações adsorvidas de IgG foram associadas aos valores das densidades ópticas obtidas no ELISA, por um modelo não linear Log-Log, calculados com auxílio do conjunto estatístico Graph Pad Prisma 5.0. Os valores de lgG específica de cada amostra foram calculados a partir do uso dos índices de variação das curvas padrões ensaiadas em cada placa, sendo que os valores iniciais obtidos em $\mathrm{ng} /$ poço eram convertidos a $\mathrm{ug} / \mathrm{ml}$, pela multiplicação pela diluição utilizada em cada amostra. 


\section{ANÁLISE ESTATÍSTICA}

Os índices de sensibilidade relativa, especificidade relativa e valores preditivos positivo e negativo foram calculados pelo programa Epilnfo 6.04, e teste para análise de concordância entre variáveis, utilizando o pacote GraphPad Prism version 5.00 for Windows, GraphPad Software, San Diego, California, USA, (www.graphpad.com). 


\section{RESULTADOS}

Toda a estratégia utilizada para nosso trabalho foi organizada de forma a permitir uma melhor compreensão, utilizando a sequencia:
a) Caracterização da saliva;
b) Avaliação das formas de coleta e a reação de lgG;
c) Padronização da ELISA;
d) Padronização do dot-ELISA;
e) Padronização do ELISA de Captura;
f) Ensaio de amostras de universitários.

\subsection{Proteína total e IgG em saliva}

Neste ensaio, procuramos avaliar a quantidade total de proteína na saliva e a quantidade de lgG nela contida e se havia relação entre estas medidas, para que pudéssemos extrapolar a quantidade de lgG pela quantidade de proteína total na saliva. Na figura 8, podemos observar a quantificação de proteína total em saliva pelo método de Bradford. Como podemos observar, a média de valores foi 295 ug/ml de saliva, com um desvio de 163 ug, o que demonstra uma grande dispersão de valores para esta medida, variando de quase $1 \mathrm{mg}$ por $\mathrm{ml}$ até menos que 50 $\mathrm{ug} / \mathrm{ml}$. 


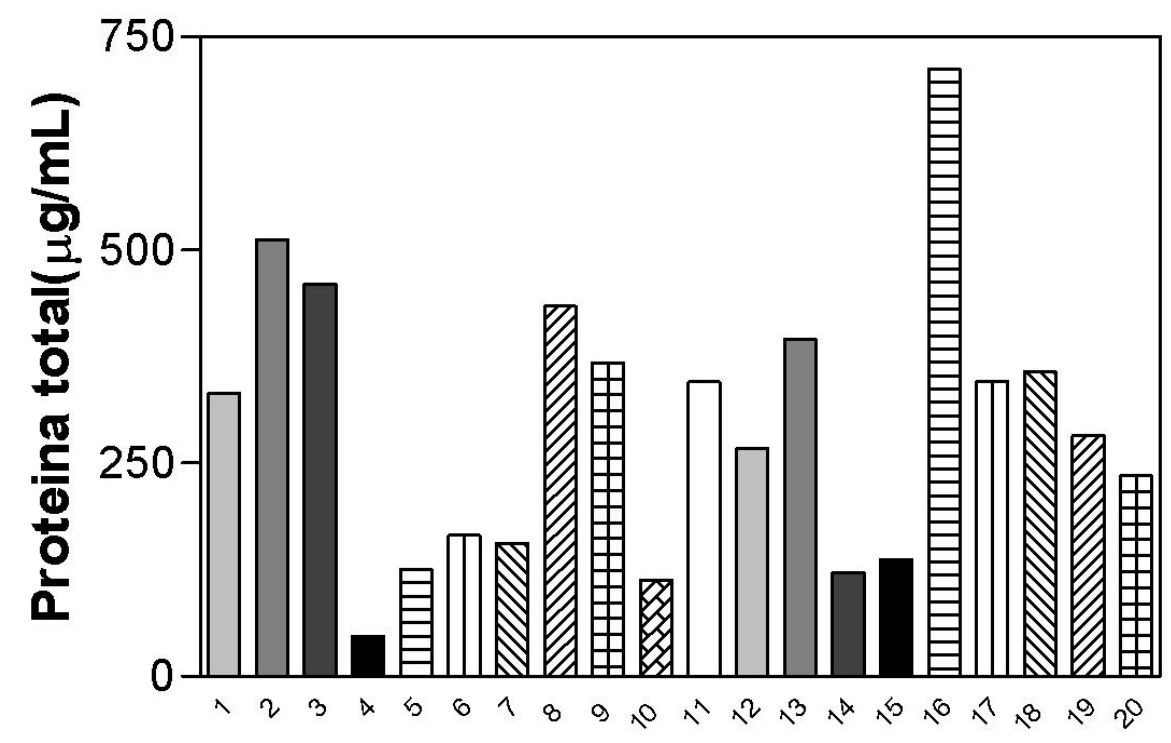

Figura 8 - Distribuição de proteína total em saliva de voluntários, determinada pelo método de Bradford, 1 a 20 amostras de saliva.

Para continuarmos a tentativa de correlação entre proteína total e $\lg G$, padronizamos uma reação imunoenzimática para a determinação de $\lg G$ total humana na saliva, a partir de uma curva de a adsorção a substrato sólido de $\lg G$ humana purificada e revelada com conjugado peroxidase específico. Esta reação pode ser observada na figura 9, onde há uma excelente relação entre a D.O. observada na reação de ELISA supracitada e a concentração submetida a adsorção no suporte sólido, permitindo a quantificação de lgG em misturas como a saliva. 


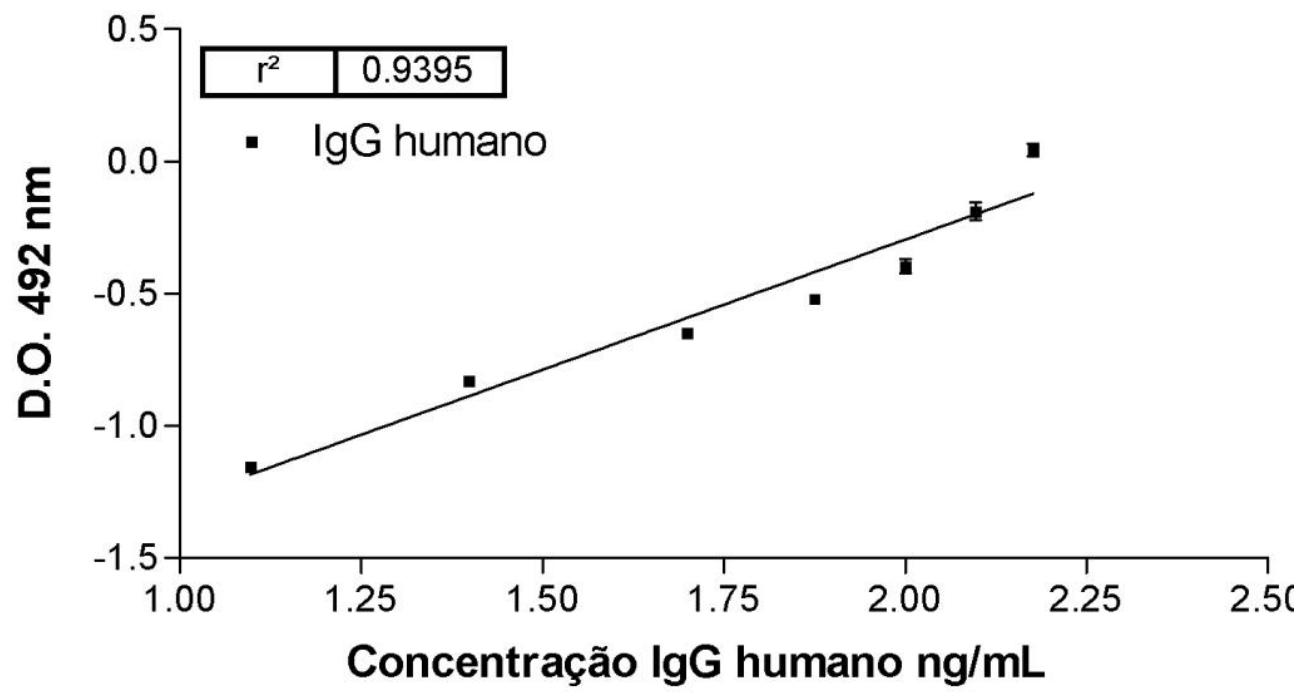

Figura 9 - Padronização da determinação de $\lg G$ humana a partir de adsorção a suporte sólido e ELISA.

Uma vez padronizada a determinação da lgG total em misturas protéicas, avaliamos a concentração de lgG nas mesmas salivas cuja proteína total havia sido determinada. O resultado da IgG total em cada saliva pode ser visto na figura 10 , onde observamos que a média de IgG total em saliva foi de $367 \mathrm{ng} / \mathrm{ml} \mathrm{com} \mathrm{um}$ desvio padrão de 305 ng. 


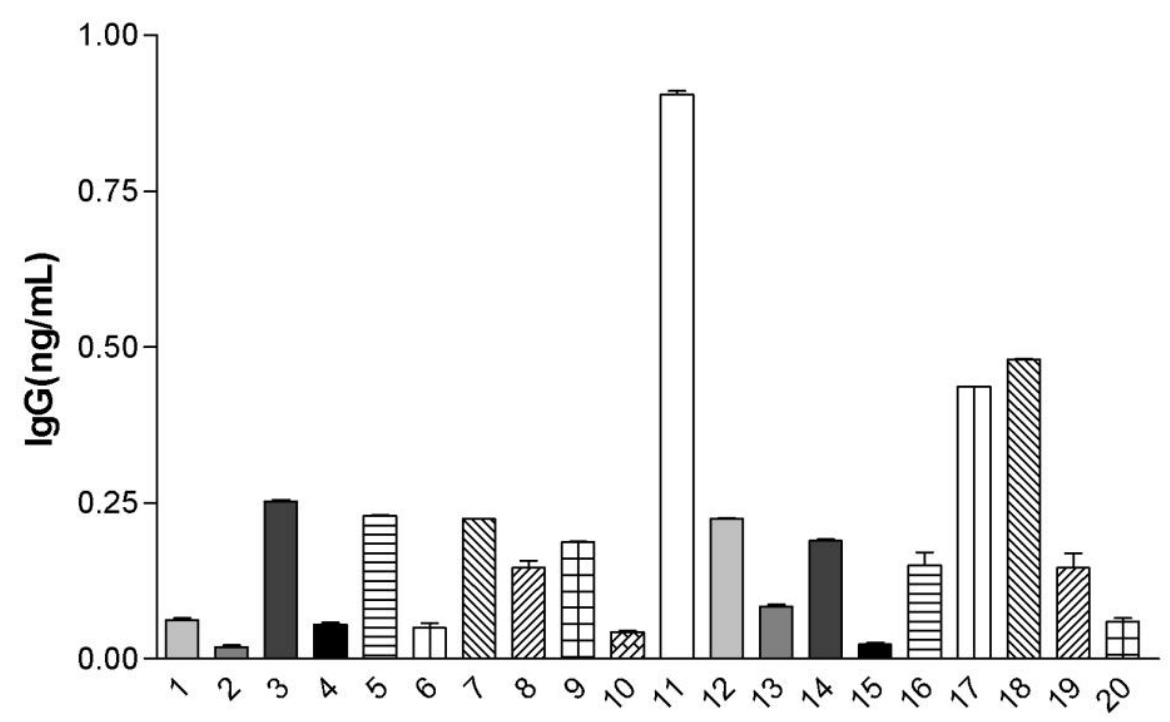

Figura 10 - Distribuição da concentração total de lgG humana em saliva (1 ao 20) de voluntários, determinada por adsorção e ELISA direto. As barras representam o desvio de duas medidas independentes.

Uma vez determinada a concentração de proteína total e a concentração de IgG na amostra, comparamos estes resultados por regressão linear e sua distribuição pode ser vista na figura 11. Como pode ser observado, não há uma correlação significativa entre as medidas apresentadas, o que impede o uso da determinação da proteína total como critério para afastamento de falso negativo em reação de pesquisa de $\lg G$ específica em saliva. 


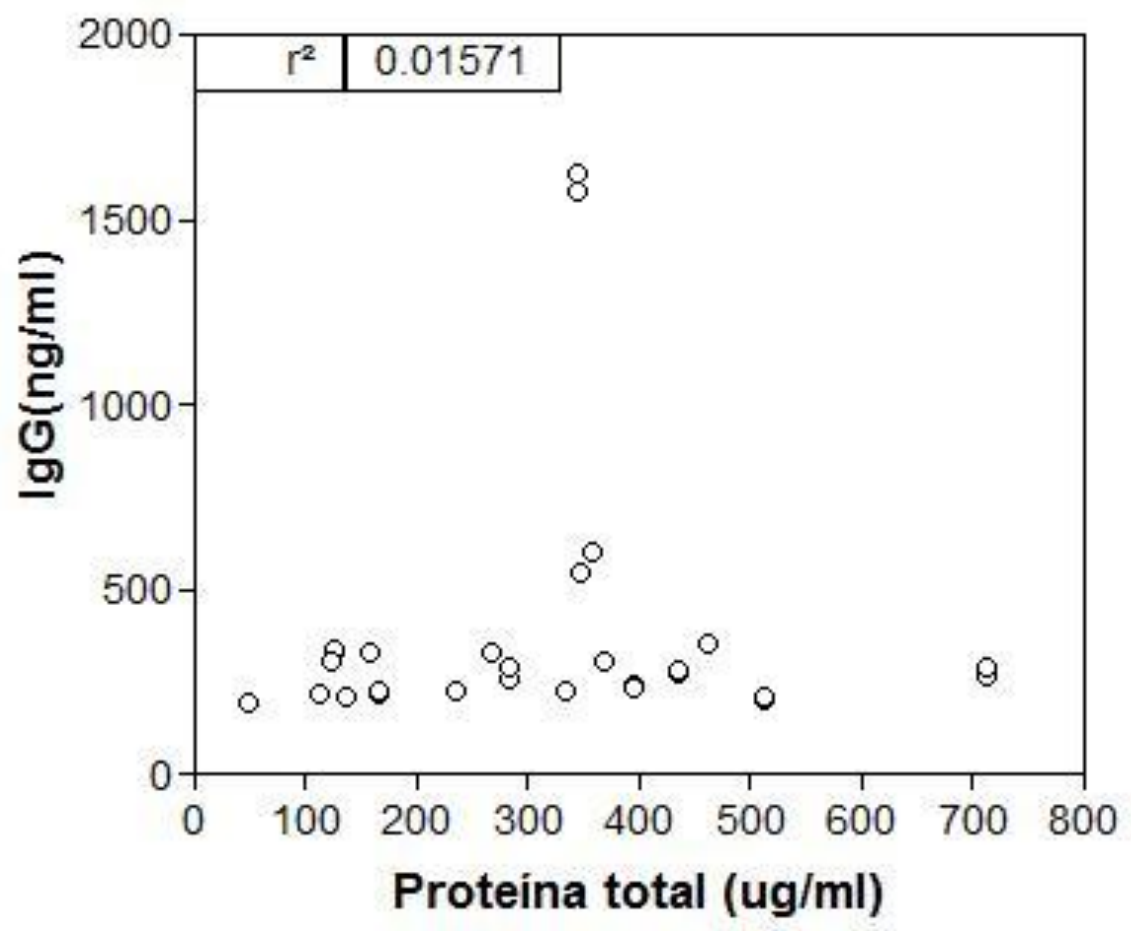

Figura 11 - Relação entre a proteína e a lgG em saliva humana de voluntários, mostrando a ausência de correlação entre as medidas.

\subsection{Comparação das formas de coleta da saliva IgG total e IgG anti - $T$. gondii}

Até o momento não há relato de um equipamento apropriado para a coleta da saliva ou disposição adequada. Tendo em vista a ausência de correlação entre a proteína total e a lgG na saliva, decidimos comparar as formas de coleta para verificar a viabilidade da saliva com ou sem enxaguante oral, com menor contaminação e com menor tempo de permanência na boca, para evitar proteólise por bactérias ou proteases.

Na figura 12, comparamos a quantidade de $\lg G$ total na saliva determinada pelo ELISA direto, após adsorção em suporte sólido, utilizando saliva colhida diretamente, após lavagem com solução de enxaguante oral contendo sorbitol e 
alcoóis (Listerine $\left.{ }^{\circledR}\right)$, e após 2 e 5 minutos de recuperação da lavagem com enxaguante oral. Como pode ser observado na figura 12, a quantidade de IgG na saliva cai significativamente após lavagem com enxaguante e rapidamente se recupera nas amostras testadas. Isto mostra que o uso de enxaguante não prejudica a coleta de IgG na saliva se esta for prolongada. Isto deve ser dependente do fato do enxaguante conter sorbitol e alcoóis, que promovem a saída de líquido crevicular para compensar a hipertonicidade resultante. Assim, o uso de enxaguante permite a coleta de uma saliva com menor quantidade de bactérias e proteases e uma quantidade recente de IgG.

\section{IgG total / saliva}

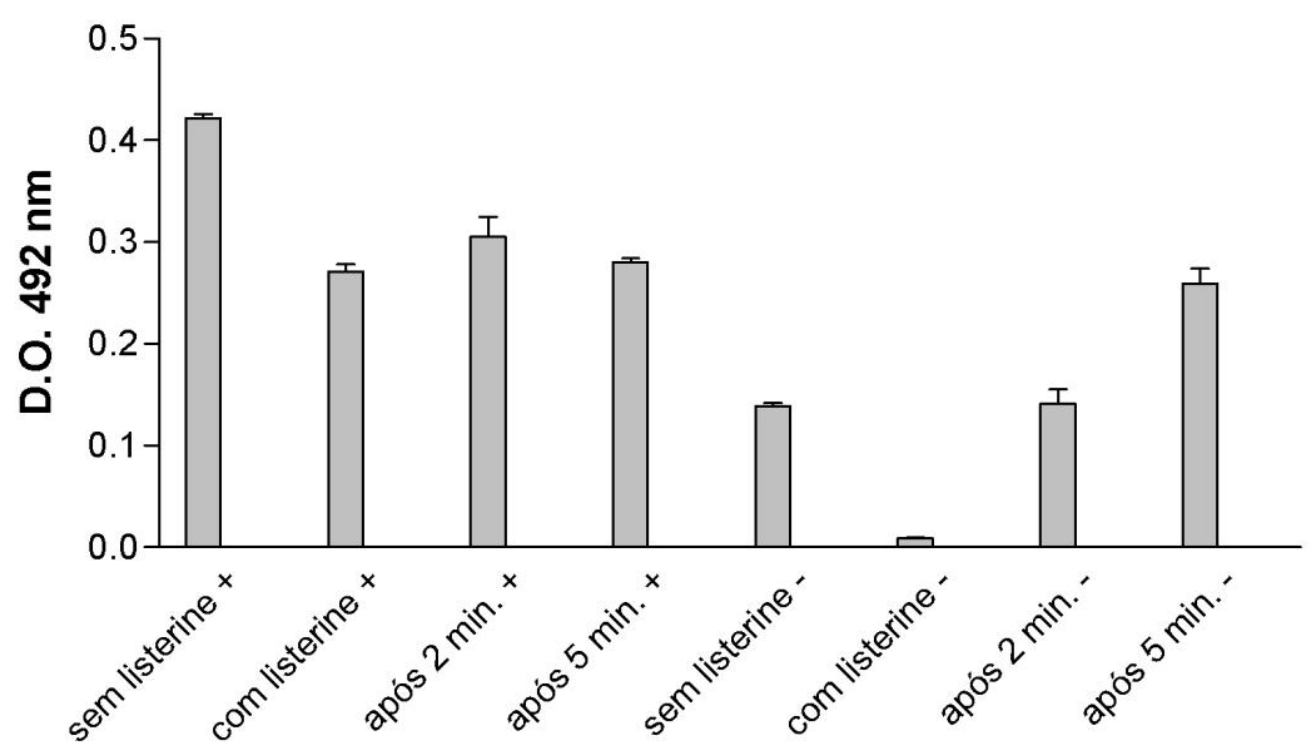

Figura 12 - Quantidade de lgG total em 02 voluntários que se submeteram a coleta seriada de saliva pré e pós uso de enxaguante oral. Os resultados são apresentados como média da D.O. de ELISA direto e a barra representa o erro padrão da média em 02 medidas.

A seguir, procedemos a determinação específica da IgG anti-T.gondii nas salivas coletadas pré e pós uso de enxaguante oral, para determinação do método 
de coleta para detecção de $\lg G$ específica, sendo que os resultados estão apresentados na figura 13. Como podemos observar, a coleta gera um efeito de lavagem na IgG da saliva, comprovada pela dosagem total de proteína (dados não mostrados). Em paciente positivo, ocorre uma queda na concentração de lgG específica, mostrando que há um efeito residual de deposição de lgG em saliva, que é reduzido pelo uso de enxaguante oral. Apesar deste efeito, pode-se notar que para o ELISA não há perda de positividade da reação de ELISA anti-T.gondii, mesmo quando a IgG total é recuperada pela saliva após enxágüe, que pode ser observada no paciente voluntário livre de T.gondii.

\section{IgG/mI em saliva}

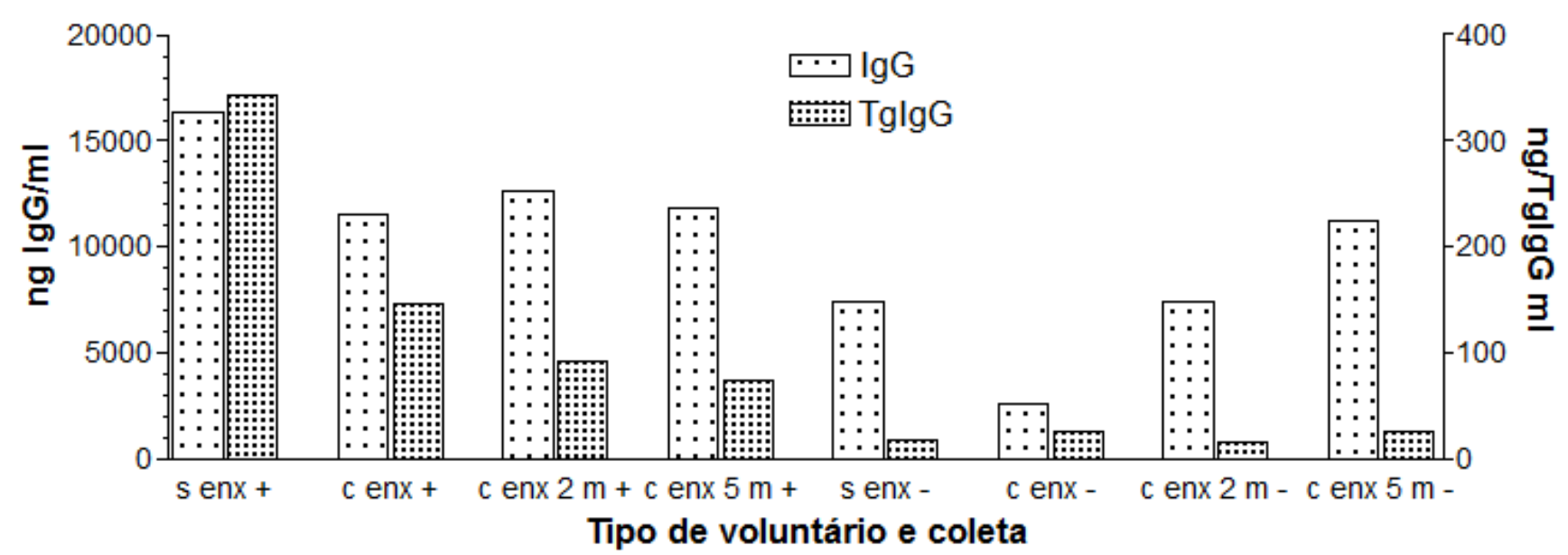

Figura 13 - Concentração de IgG e de IgG específica contra T.gondii após vários tipos de coleta (s enx + ou - sem enxaguante positivo ou negativo; c enx + ou - com enxaguante positivo ou negativo; c enx $2 \mathrm{~m}+$ ou - com enxaguante positivo ou negativo após 2 min. e c enx $5 \mathrm{~m}+$ ou - com enxaguante positivo ou negativo após $5 \mathrm{~min}$.) em voluntários positivos ou negativos para toxoplasmose. 
Em nossos ensaios subsequentes, optamos por utilizar a coleta após enxaguante e por um tempo longo, para permitir uma melhor concentração de $\lg G$ e afastar eventuais contaminações por bactérias residentes ou efeito de proteases.

\subsection{ELISA convencional "Padrão ouro" para determinação de anticorpos anti -} T. gondii

As amostras de soro e saliva foram submetidas ao teste convencional de ELISA que foi considerado nosso padrão ouro para análise da sensibilidade relativa, especificidade relativa e valores preditivos positivos e negativos para 0 teste de dot-ELISA e ELISA de captura. As amostras de soro foram ensaiadas na diluição 1/100 e reveladas com o cromógeno OPD. Dos 20 soros e salivas testados, 4 foram reagentes ao T.gondii e 16 foram não reagentes (figuras 14 e 15), com clara distinção entre amostras positivas e negativas para ambos fluidos biológicos, confirmando o potencial uso da saliva para diagnóstico de anticorpos anti- $T$. gondii. 


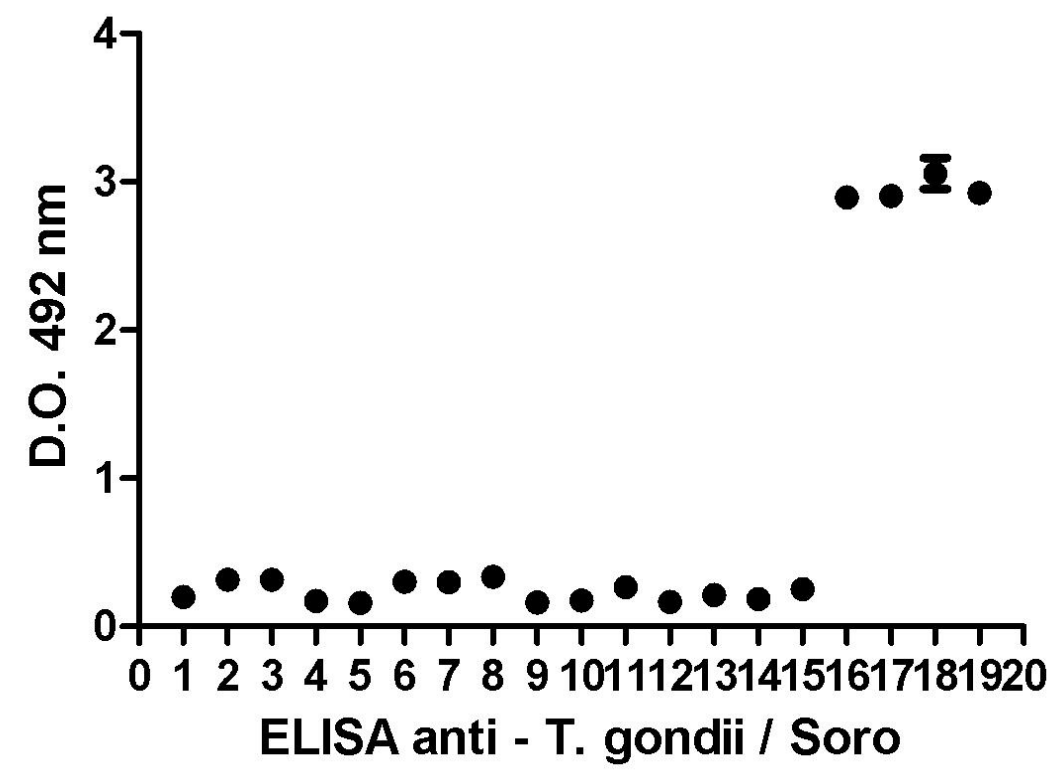

Figura 14 - Resultados do teste imunoenzimático ELISA para amostras de soro humano (com quatro indíviduos positivos e 16 negativos para infecção do T. gondii).

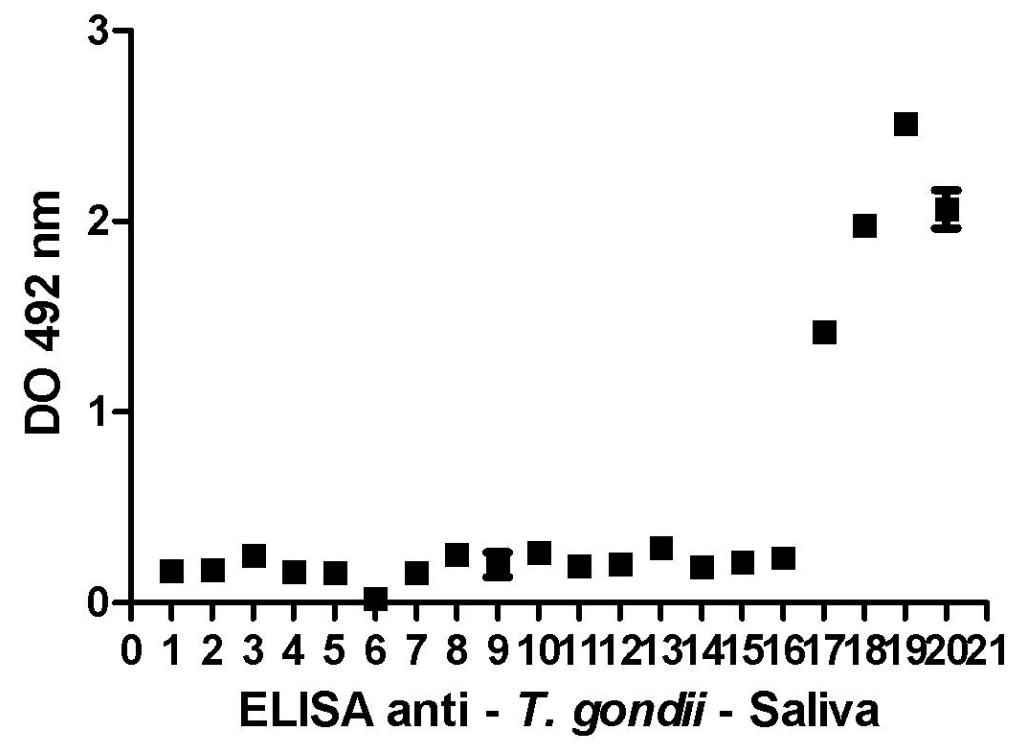

Figura 15 - Resultados do teste imunoenzimático ELISA para amostras de saliva humana (com quatro indíviduos positivos e 16 negativos para infecção do T. gondii). 


\subsection{Determinação de IgG Específico por dot - ELISA}

Para padronização da reação de dot-ELISA, utilizamos 20 soros na diluição 1/100 frente a 20 amostras de saliva (figura 16). O dot-ELISA com antígeno salino apresentou resultados concordantes com o teste padrão (ELISA), identificando 16 amostras negativas e 4 amostras positivas, tanto para as amostras de soro como de saliva, com sensibilidade de 100\% (IC95\% 40-100) e especificidade de 100\% (IC $95 \% 80-100)$.

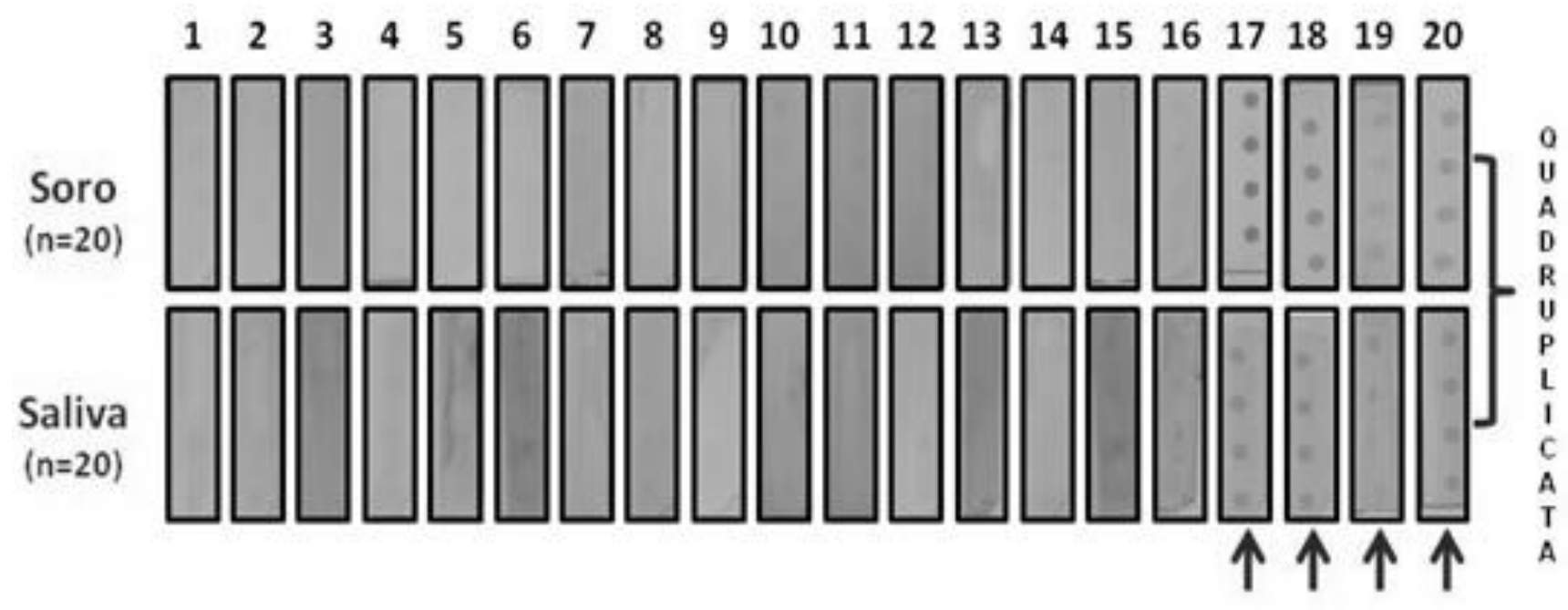

Figura 16 - Resultado dot-ELISA com antígeno salino, utilizando amostras de soro e saliva de voluntários do Laboratório de Protozoologia - IMT - SP. As setas indicam as amostras positivas. 


\subsection{Captura com proteína A}

\subsubsection{Diluição antígeno anti- T. gondii biotinilado}

Apesar dos resultados excelentes obtidos com o dot-ELISA, este é um teste qualitativo que depende da observação pessoal dos dots, ao contrário do ELISA. Neste contexto, imaginamos um ensaio que tivesse um ligante que determinasse uma quantidade fixa de IgG no suporte sólido de ELISA e a revelação utilizando um antígeno de T.gondii conjugado direta ou indiretamente à peroxidase.

Esta padronização foi realizada para que pudéssemos verificar a concentração protéica ideal para os testes de captura. A primeira parte do ensaio foi a construção de um antígeno total de T.gondii ligado a biotina que apresentasse uma reatividade suficiente para determinação imunoenzimática, como demonstradona figura 17. Como pode ser observado, na concentração 1/40 do antígeno havia uma densidade óptica reagente de 0.5 D.O., que foi considerada suficiente para avaliar uma possível reatividade de anticorpos ligados à proteína $\mathrm{A}$.

\section{Diluição Ag toxo biotinilado}

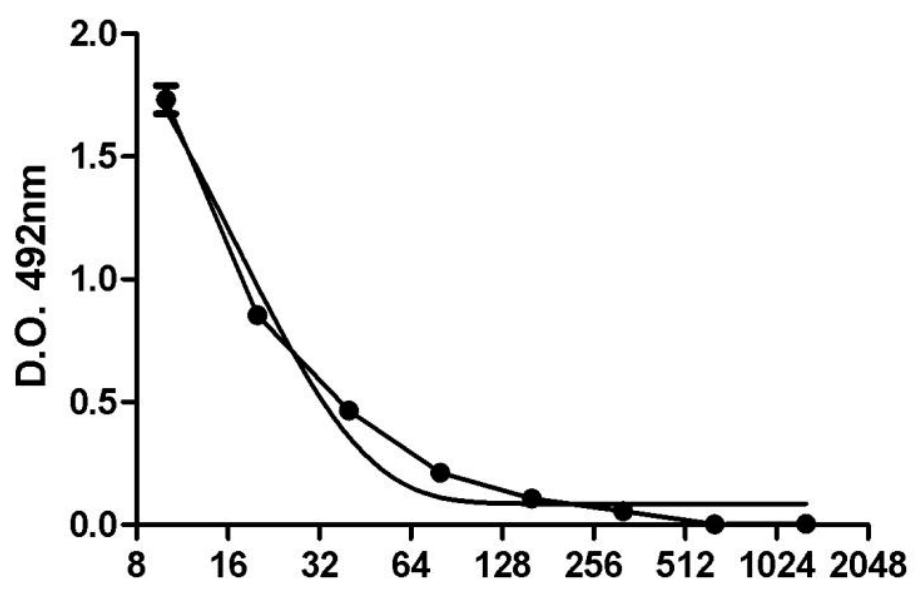

Figura 17 - ELISA direto de antígeno de T.gondii biotinilado aderido ao suporte sólido e revelado com concentração fixa de avidina peroxidase. 


\subsubsection{ELISA de captura soro}

O ELISA de captura foi inicialmente padronizado com soros conhecidos. Esta técnica imunológica baseia-se no fato de que os anticorpos ligam-se a proteína $A$, que é previamente adsorvida no suporte sólido. Mesmo com as sucessivas lavagens, teoricamente só restarão nas placas o complexo formado pela proteína $A$ e IgG e revelados pelo antígeno que apresenta biotina que será revelada pelo complexo avidina-peroxidase. A reação foi feita com placas adsorvidas com 10ug/ml de Proteína A, incubadas como descrito em Métodos e com uma diluição 1/100 de soro. A seguir, as amostras foram incubadas com antígeno biotinilado 1/40 e reagidas com complexo avidina peroxidase. Foram utilizados dois tipos de cromógenos de diferentes sensibilidades, TMB e OPD, e os resultados podem ser observados na figura 18 A (TMB) e B (OPD). Trabalhamos com um controle sem antígeno biotinilado que não mostrou reação com nenhuma amostra. 


\section{A}

Soro / Ag toxo biotinilado / TMB

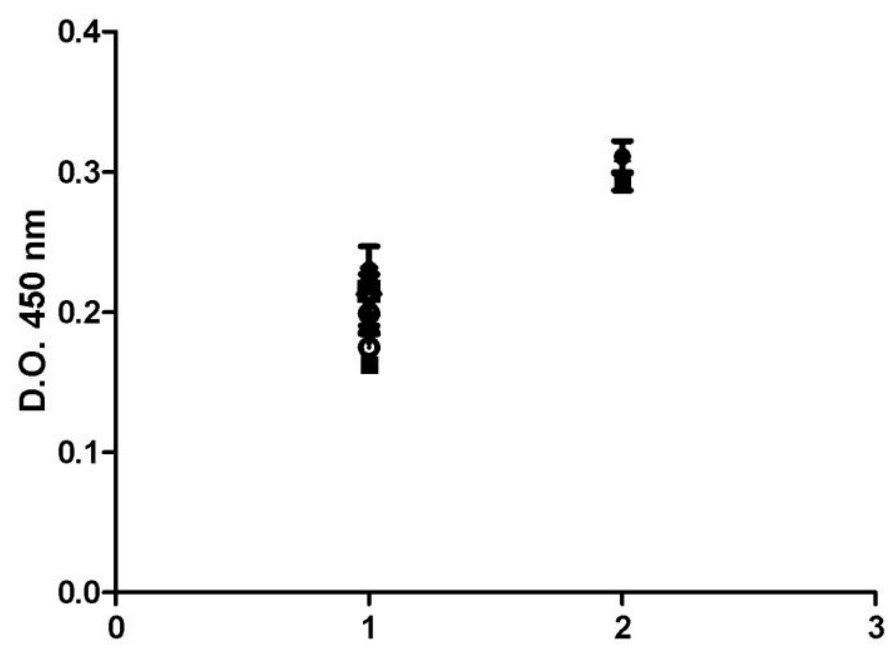

B

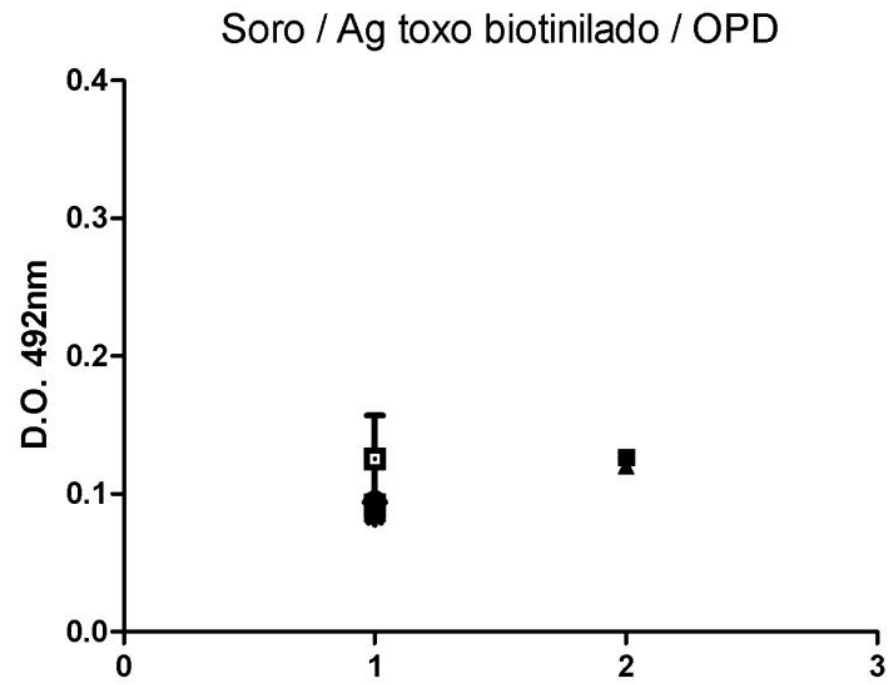

Figura 18 - Resultados do teste imunoenzimático ELISA de captura para amostras de soro humano, utilizando antígeno de $T$. gondii biotinilado, revelado com TMB (A) e OPD (B). 1 - Amostras negativas para $\operatorname{lgG} \operatorname{Tg}(n=16)$ e 2- Amostras positivas para $\lg G \operatorname{Tg}(n=4)$. 
Como pode ser observada, a distinção dos cromógenos foi mais evidente quando o TMB foi utilizado, embora houvesse a mesma distinção com o OPD, porém com menor intensidade. A interação da proteína A com a lgG confere uma alta resistência e estabilidade ao complexo formado, igualando a quantidade de imunoglobulinas absorvidas na placa.

\subsubsection{ELISA de captura saliva}

A reação de ELISA captura para saliva foi ensaiada da mesma forma que acima descrito para soros e seu resultado pode ser observado na figura $19 \mathrm{~A}$ e B, utilizando os cromógenos de diferentes sensibilidades. Notamos que o poder discriminante foi maior na saliva do que no soro, com melhor distinção entre pacientes positivos e negativos, independente do cromógeno utilizado. 


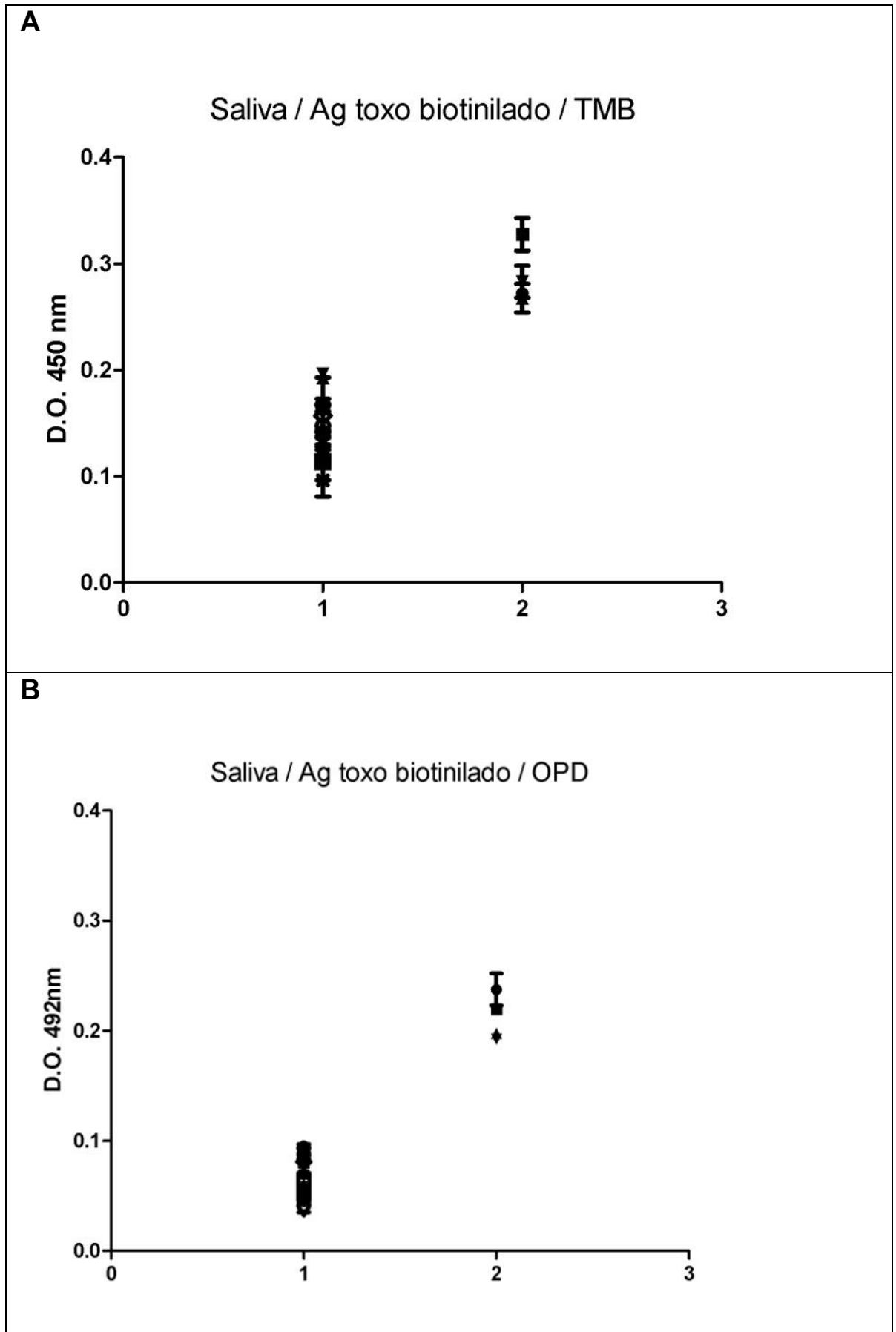

Figura 19 - Resultados do teste imunoenzimático ELISA de captura para amostras de saliva humana, utilizando antígeno de T. gondii biotinilado, revelado com TMB (A) e OPD (B). 1 - Amostras negativas para $\lg G \operatorname{Tg}(n=16)$ e 2 - Amostras positivas para $\lg G \operatorname{Tg}(n=4)$. 


\subsection{4 dot-ELISA proteína A}

Foi possível distinguir claramente as salivas positivas, com duas marcações (dot) bem definidas, dos soros negativos, sem marcação visível, ou com apenas uma pequena marcação de fundo sem definição, que corresponde ao background da reação. Como controle do teste, todas as fitas tinham o dot de Proteína $A$ revelados.

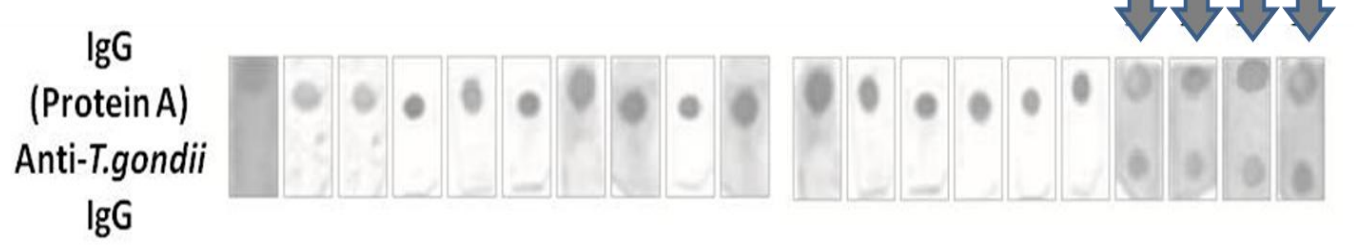

Figura 20 - Resultado dot-ELISA Proteína A, utilizando amostras de saliva de voluntários do Laboratório de Protozoologia - IMT - SP. As setas indicam as amostras positivas (marcação de dois dots).

A figura 20 mostra a sensibilidade, especificidade de $100 \%$ corroborando com os resultados obtidos no dot-ELISA com antígeno salino e ELISA convencional do soro e saliva. Estes dados mostram que o dot-ELISA Proteína A é capaz de detectar todas as amostras de saliva provenientes de indivíduos com infecção pelo T.gondii, assegurando que o resultado com a marcação de proteína A equivale ao controle do teste. 


\subsection{Aplicação da técnica de ELISA captura e dot-ELISA nas 100 amostras}

Após padronização dos ensaios imunoenzimático ELISA captura e dotELISA para detecção de anticorpos IgG anti-T.gondii em amostras de saliva, os testes foram aplicados em 100 amostras de saliva de estudantes universitários voluntários, como descrito em Métodos.

\subsubsection{ELISA captura em saliva de universitários}

Os métodos de ELISA captura foram aplicados a 100 amostras de saliva de universitários voluntários, sendo que a distribuição dos resultados quantitativos destas amostras pode ser visto na figura 21 . Os testes foram realizados em quadruplicatas sendo que duas duplicatas foram reagidas com o cromógeno clássico, o OPD, e duas reagidas com o cromógeno de maior sensibilidade, o TMB. Como pode ser observado, há uma discrepância de resultados na dependência do cromógeno utilizado. O cromógeno OPD não foi capaz de distinguir duas populações de amostras quanto à sua reatividade geral, mantendo-se em um nível de reatividade muito baixo, próximo ao cut-off de negativos. A média de seus valores ficou abaixo de 0.1 Absorbância $490 \mathrm{~nm}$. Já o cromógeno TMB, de maior sensibilidade, apresentou uma reatividade diferencial significativa, com 20 amostras apresentando uma reatividade maior que 0,6 Absorbância $450 \mathrm{~nm}$, diferenciando-se da média de reatividade do grupo, que estava em 0.4 Absorbância 450 nm e que também era diferente do grupo de 80 amostras que apresentava valor de reatividade menor que esta média. Usando estes critérios de comparação com a média, atribuímos ao grupo reagente o critério positivo para IgG anti T.gondii, sendo os demais considerados negativos para o ensaio. 


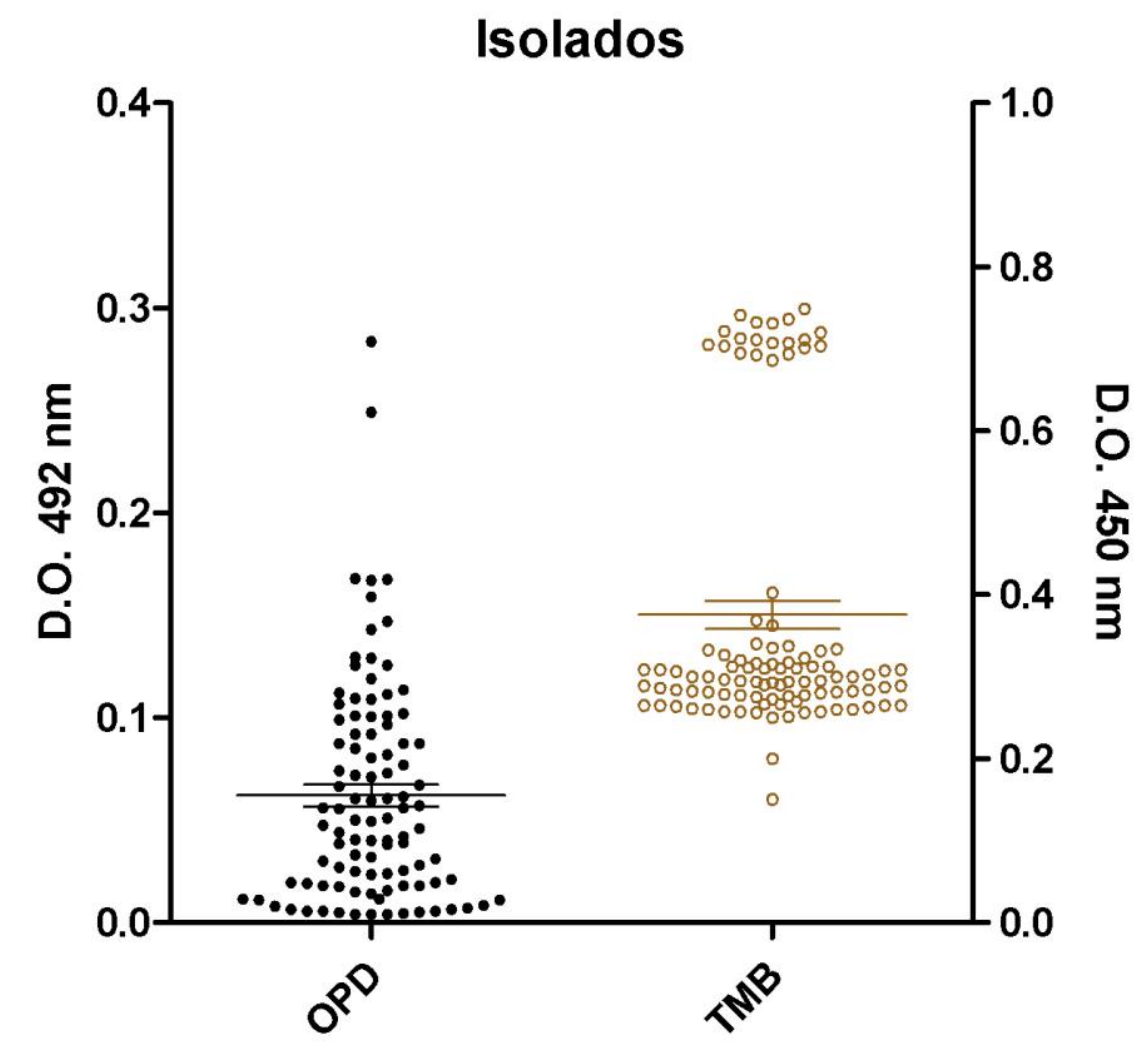

Figura 21 - Resultados do teste imunoenzimático ELISA de captura para 100 amostras de saliva humana, utilizando antígeno de T. gondii biotinilado, revelado com TMB e OPD.

A partir destes dados, selecionamos as amostras positivas e negativas no TMB e analisamos sua resposta individual no OPD, que mostrou correlação adequada de valores, como pode ser observado na figura 22. A média dos valores das amostras reagentes no TMB foi também maior quando analisado pela OPD, mas de uma forma menos eficiente, com uma distribuição interpenetrada entre os valores positivos e negativos neste cromógeno, que deve ser devido a sua menor sensibilidade.

Interessante notar que se utilizando o cut-off da média mais 2 desvios nas amostras negativas, 03 amostras negativas poderiam ser consideradas reagentes 
nesta reação. Acreditamos que este ensaio é muito sensível e a discriminação foi excelente e não devemos considerar este valor como cut-off absoluto.

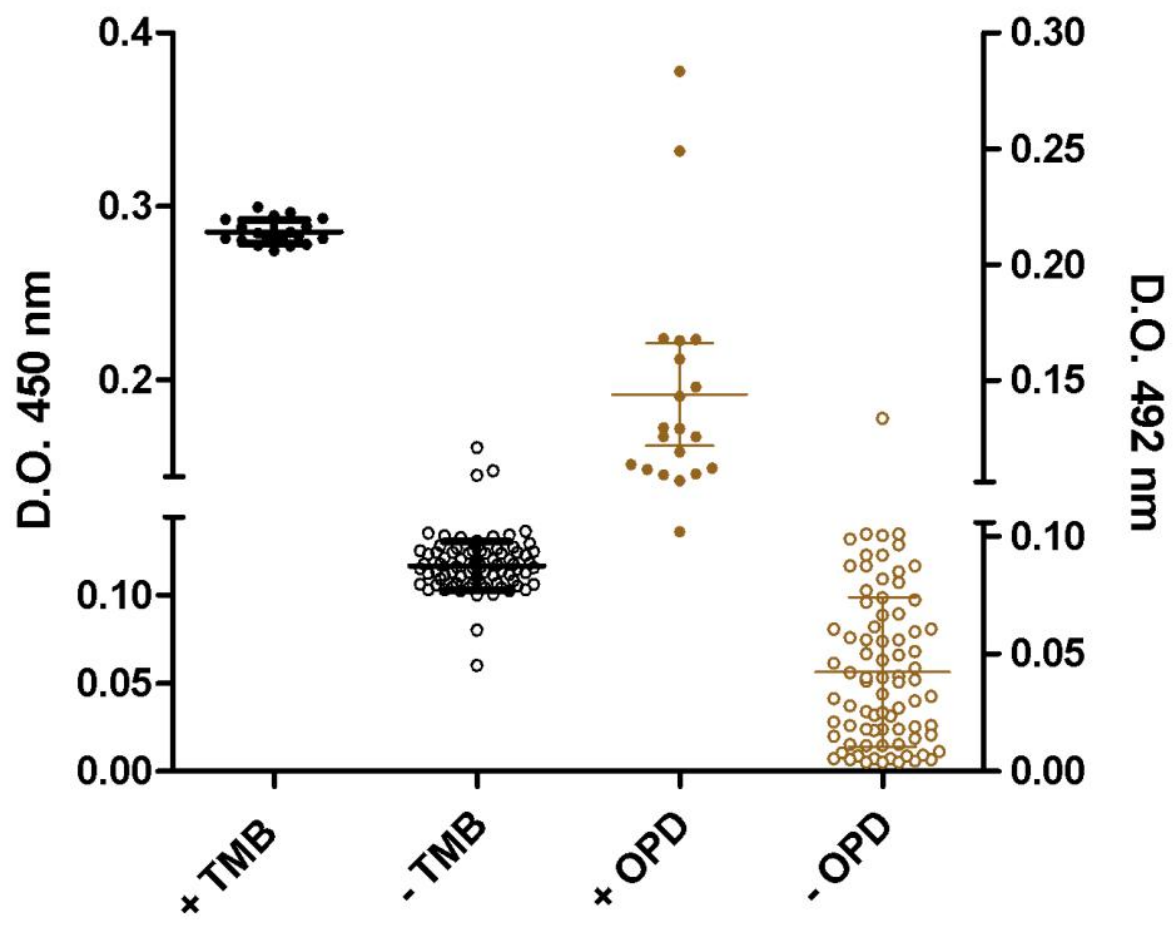

Figura 22 - Distribuição de resultados quantitativos no ELISA de captura, utilizando TMB e OPD, discriminados pelo resultado putativo de positividade no TMB, em 100 amostras de saliva humana, utilizando antígeno de $T$. gondii biotinilado e avidina peroxidase. Os cut-offs utilizados foram calculados com base nas amostras negativas, pela soma de 2 desvio padrões à media dos valores.

\subsection{2 dot - ELISA proteína A 100 amostras de saliva}

Como confirmação de reação da saliva, as amostras foram ensaiadas para seu conteúdo de IgG e para sua reatividade contra T.gondii de forma quantitativa, utilizando um dot-ELISA com dois dots de captura, um contendo proteína A para detecção de IgG e outro dot com Ag.T.gondii para determinação de reatividade 
específica. Assim, uma amostra sem IgG não daria nenhum dot positivo, uma amostra negativa somente o dot de cima de proteína $A$, dado que a lgG está presente, mas não reagente com o antígeno e os dois dots marcados significam uma reação positiva para toxoplasmose, confirmada pela presença de $\lg G$ na amostra. Como pode ser observado na figura 23 , todas as amostras de saliva continham IgG e somente 19 eram reagentes nos dois dots, portanto continham IgG anti-T.gondii. 


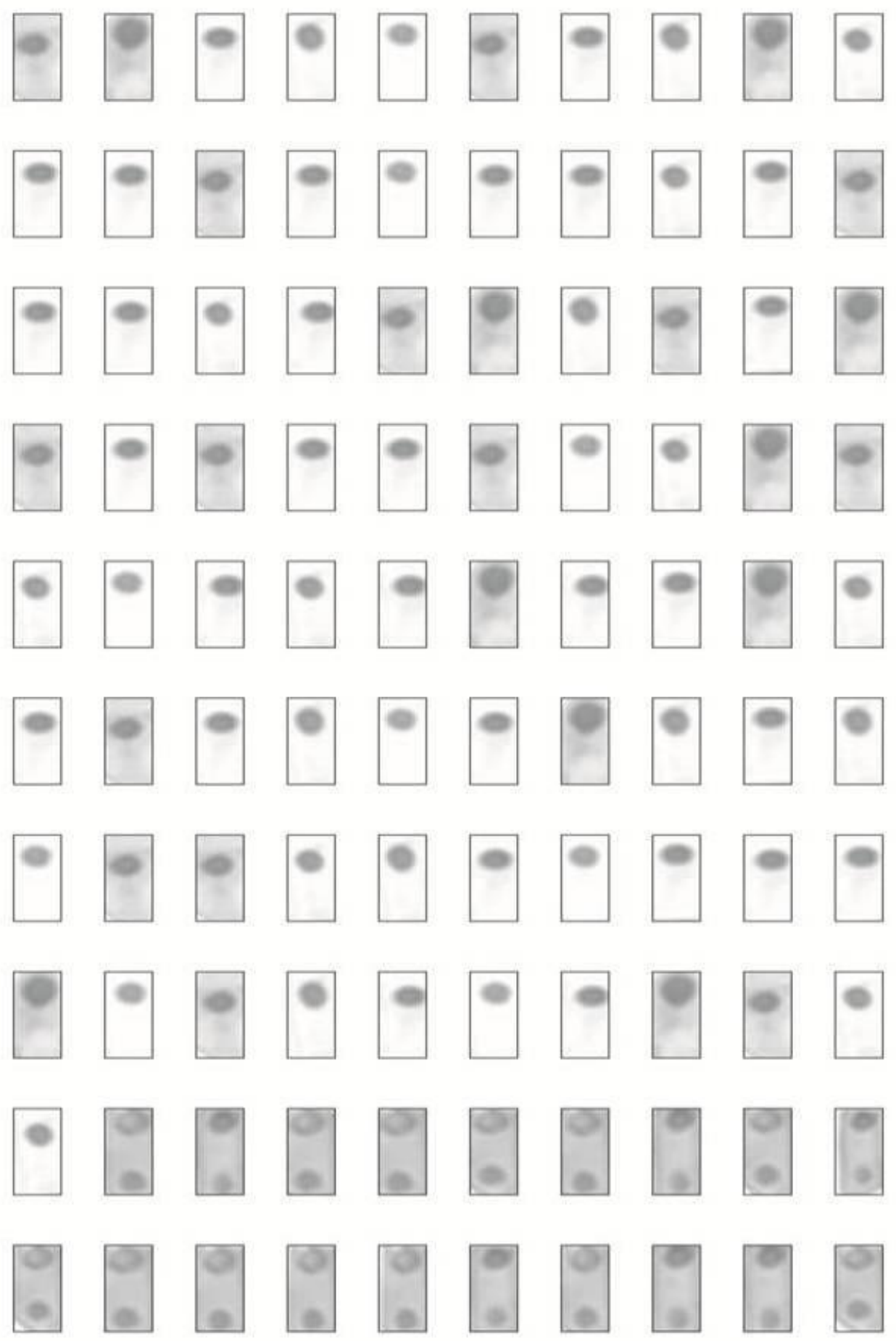

Figura 23 - Resultado dot-ELISA Proteína A, utilizando 100 amostras de saliva de voluntários. As marcações com dois dots indicam as amostras positivas (19) e marcações com um dot indicam amostras negativas (81). 
Esta reação foi considerada o padrão ouro para a determinação da presença de IgG anti-T.gondii e, portanto, para identificar a infecção pelo T.gondii na população de universitários, resultando numa frequência de positividade de 19\% com intervalo de confiança de $95 \%$ de 11,8 a $28.1 \%$.

\subsection{3 Índices de eficiência das reações de ELISA captura, utilizando-se o dot- ELISA como padrão ouro}

Utilizando-se a reação de dot-ELISA foi possível identificar 19 amostras positivas e 81 negativas. Esta distribuição de valores utilizada como padrão ouro permitiu estimar os índices de eficiência das reações imunoenzimáticas de captura, que pode ser vistana tabela 3 para o cromógeno TMB e na tabela 4 para o OPD.

O uso do cromógeno TMB mostrou índices sorológicos maiores que 95\%, com alta eficiência e apenas um falso positivo, o que recomenda seu uso futuro.

Tabela 3 - Resultados de sensibilidade relativa, especificidade relativa, valor preditivo positivo e valor preditivo negativo do teste ELISA de captura utilizando o cromógeno TMB.

\begin{tabular}{lll}
\hline TMB & ELISA(+) & ELISA(-) \\
\hline Dot- ELISA (+) & 19 & 0 \\
Dot- ELISA (-) & 01 & 80 \\
Sensibilidade & $95 \%$ & IC 95\%: 75-99.8 \\
Especificidade & $100 \%$ & IC 95\%: $95.5-100$ \\
Valor preditivo (+) & $100 \%$ & IC 95\%: $82,3-100$ \\
Valor preditivo (-) & $98.8 \%$ & IC 95\%: $93-99,8$ \\
\hline
\end{tabular}


Tabela 4 - Resultados de sensibilidade relativa, especificidade relativa, valor preditivo positivo e valor preditivo negativo do teste ELISA de captura, utilizando o cromógeno OPD.

\begin{tabular}{lll}
\hline OPD & ELISA(+) & ELISA(-) \\
\hline Dot ELISA(+) & 19 & 0 \\
Dot ELISA (-) & 04 & 77 \\
Sensibilidade & $82.6 \%$ & IC95\%: 61-95 \\
Especificidade & $100 \%$ & IC95\%: 95-100 \\
Valor preditivo (+) & $100 \%$ & IC95\%: 82-100 \\
Valor preditivo (-) & 95 & IC95\%: 88-99 \\
\hline
\end{tabular}

O uso do cromógeno OPD foi um pouco diferente, com 04 amostras falso positivas, mas nenhuma amostra falso negativa. Este ensaio precisa ser aprimorado para seu uso em amostras de saliva, já que como apresentou alta sensibilidade, mas uma maior variação de sinal e algumas amostras sobrepostas e uma aparente zona cinza de maior tamanho. 


\section{DISCUSSÃO}

Nossos dados bioquímicos de saliva mostram que a quantidade de proteínas na saliva não se correlaciona com a quantidade de anticorpos IgG nela contida. Estudos prévios demonstraram a presença de anticorpos em saliva (Kraus e Konno, 1963), mas sempre se acreditou numa relação entre a proteína total e a quantidade de anticorpos. Esta discrepância pode ser causada por vários motivos. A quantidade de liquido crevicular depende do estado de inflamação das gengivas (Lamster e Ahlo, 2007). A composição da saliva secretada pode variar com situações hormonais ou emocionais, mas esta secreção não incluí as imunoglobulinas (Helmerhorst e Oppenheim, 2007). A higiene bucal deficiente e estes fatores também interferem na microflora bucal e na quantidade de bactérias, o que gera mais fatores de confusão para uma análise global de proteína como marcador da quantidade de IgG na saliva.

Os nossos resultados para análise da proteína total salivar, corroboram com os autores Humphrey et al., (2001) e Lauria-Pires (2008), pois o fluxo salivar e a composição da saliva podem ser alteradas em função da idade, peso, uso de medicamentos e variações hormonais decorrentes de condições clínico/fisiológicas e climatério.

Outro dado interessante, a confirmação da facilidade da coleta de saliva em crianças, foi descrito por Smith e colaboradores, (1992) quando pesquisavam o efeito da idade na concentração de $\lg G$, $\lg A$ e $\lg M$ na saliva, concluindo que a concentração de $\lg$ A da saliva foi menor nos indivíduos de mais idade, não havendo diferenças significativas em $\lg G$ e $\lg M$ da saliva labial e da parótida.

Nossa opção foi utilizar uma saliva recém-secretada para uniformização das reações, sendo que encontramos a mesma discrepância anterior. Confirmamos 
este resultado pelo ensaio ELISA com proteína A de S.aureus na fase sólida, o que permitiu a detecção de quantidades significativas de $\lg G$ nas amostras dos voluntários. O uso de enxaguante oral mostrou maior eficiência na produção de uma melhor quantidade de liquido crevicular na saliva, já que o enxaguante contendo etanol e glicerol induzia uma saída osmótica do liquido crevicular que era misturado a uma saliva recém-secretada com menor quantidade de bactérias da microflora (Albert-Kiszely et al, 2007), dependente de algum tempo (minutos) para sua ação.

Isto permitiu um ensaio imunoenzimático para detecção de anticorpos lgG anti T.gondii em amostras de saliva, que foram pareadas com a amostra de soro de 20 voluntários, mostrando que há uma clara distinção entre positivos e negativos para T. gondii, tanto no soro como na saliva. Isto já havia sido proposto por Macre (2008) num ensaio onde a saliva era concentrada 10 vezes, com bons resultados. O uso de saliva geralmente apresenta bons resultados com alta sensibilidade em ensaios de detecção de antígenos de HIV (Parisi et al., 2009), mas existe uma preocupação constante com a sensibilidade dos ensaios, que frequentemente podem apresentar fração importante de falso negativos, que pode chegar até a $20 \%$ das amostras (Pil et al., 2010) Nosso ELISA foi eficiente e sensível, mas em uma amostra controlada.

Estudo feito por Stroehle (2005) ressalta a importância da utilização da saliva como material por não ser um método invasivo, mas destaca que é necessário mais estudos para melhorar o tratamento e coleta da saliva. A toxoplasmose é uma zoonose cosmopolita onde meio bilhão da população mundial possui anticorpos anti - T. gondii. Geralmente, a toxoplasmose é uma doença assintomática, sendo assim o melhor diagnóstico seria a sorologia, mas este é um método invasivo de uso inadequado em grupos protegidos como crianças (Macre, 2008). 
Os métodos de detecção de anticorpos estão frequentemente voltados para pesquisas em amostras de soro, porém mais recentemente até específicas para T. gondii. O pioneiro em detecção de anticorpos anti $-T$. gondii em saliva foi Hajjer (1994), utilizando a técnica de immunoblotting com antígeno proveniente de taquizoítos suspensos em salina (antígeno salino), muito similar ao nosso antígeno e os resultados obtidos por ele no immunoblot saliva IgG específico foi detectado em 20 amostras de saliva das 27 salivas de pacientes recém - infectados, sendo a banda mais freqüente a banda da proteína 38/KDa.

Em estudos para detecção da toxoplasmose por anticorpos em saliva, utilizando ELISA, foi encontrada uma especificidade de $99,5 \%$ e valor preditivo positivo de $99,0 \%$, indicando que poderia ser um teste de saliva verdadeiramente positivo, no entanto, a sensibilidade foi de $33,8 \%$ e o valor preditivo negativo foi de $49,4 \%$ sendo valores baixos, não tendo um bom resultado, por não mostrar os pacientes com infecção pelo Toxoplasma gondii, em sua totalidade, indicando mais uma vez que nosso teste dot-ELISA utilizando saliva foi mais eficiente (Dave et al. 1996).

Pesquisando anticorpos anti - T. gondii em saliva de pacientes com HIV, com o teste ELISA, Singh (2005), apresentou uma especificidade de $94,67 \%$ e sensibilidade de $85,7 \%$ para $\lg$, mostrando novamente que nosso teste possui taxas de sensibilidade e especificidade maiores.

Nossa abordagem procurou afastar a possibilidade de falso negativos da metodologia anterior proposta por Macre (2008), decorrentes da ausência de quantidades significativas de $\lg G$. A ideia foi usar um ligante especifico para $\lg G$ e a seguir ensaiar tanto a IgG com sua especificidade em ELISA e dot-ELISA.

A proteína A de Staphilococcus aureus liga-se a parte Fc de duas imunoglobulinas, com exposição da parte Fab, contendo o sitio de reconhecimento do antígeno (Langone et al., 1978). Sua adsorção a suporte sólidos garante uma 
quantidade igual de $\lg G$ e maior especificidade do teste, bastando a criação de um antígeno marcado. Estes ensaios de captura podem utilizar diferentes suportes sólidos, como superfície de placas de ELISA ou membranas porosas de alta capacidade de ligação, pelo que padronizamos diferentes ensaios.

Até a presente data deste estudo, não há relatos na literatura, demonstrando a utilização do teste dot-ELISA para detecção de anticorpos anti - T. gondii em saliva. O estudo que mais se aproxima com o nosso foi o realizado por Stroehle (2005), onde avaliou anticorpos IgG na saliva pelo teste immunoblotting comparando com o ELISA, onde foi demonstrado que o immunoblotting possui alta sensibilidade $(98,3 \%)$ e especificidade (100\%), sendo que estes resultados são semelhantes aos obtidos para detecção de anticorpos lgG anti - rubéola realizado por Morris (2002), concordando também com nossos resultados.

As reações utilizando a ligação de antígenos biotinilados apresentaram uma reatividade baixa, que poderia ser causada pela pequena quantidade de anticorpo ligado a proteína A do suporte sólido, mas o uso de reagente de peroxidase mais sensíveis como o TMB resultou em um ensaio de alta discriminação entre amostras positivas e negativas e de forma quantitativa, que inclusive pode ser usada em sistemas automatizados.

Neste contexto, efetuamos a padronização do ensaio imunoenzimático como dot-ELISA proteína A para detecção de anticorpos lgG anti - T. gondii em saliva, uma vez que há relatos na literatura (Matsumoto, 1990), indicando que o teste dotELISA, apresenta alta sensibilidade, alta especificidade, baixo custo e por ser um sistema que utiliza membrana, possibilita a utilização de saliva como material biológico, por necessitar de pequenas quantidades de amostras e ELISA de captura com proteína A.

Para diminuir a variação de IgG em nossos testes escolhemos a proteína $A$ para garantir uma quantidade de IgG fixa e com isso aumentando a especificidade 
do nosso teste, uma vez que ela tem sido usada há muito tempo para desenvolvimento de testes de captura de anticorpos de fluídos biológicos (Yang, 2007). Uma vez que a afinidade da proteína A por imunoglobulinas, são de grande uso para técnicas imunoquímicas (Langone, 1982), isto levou a sua indicação na imunologia em técnicas de cromatografia por afinidade e captura.

Em nosso trabalho, otimizamos os ensaios de dot-ELISA e ELISA com alta sensibilidade e especificidade, permitindo a detecção de $\lg$ em pequenas quantidades de material, que é extremamente importante no caso da saliva, que apresenta baixa concentração de IgG. Além disso, pudemos assegurar que o resultado era realmente lgG, ao utilizar os métodos de captura com proteína $A$. Outros autores já haviam relatado a importância e aplicabilidade da reação de dotELISA para outras protozooses como a Doença de Chagas (Matsumoto et al., 1990), mas para a toxoplasmose estes dados são escassos (Brooks et al., 1985), sempre utilizando soro como fonte de anticorpos.

Os resultados do dot-ELISA, utilizando o antígeno salino, demonstraram resultados semelhantes com uma clara discriminação entre as amostras positivas e negativas, para ambas as amostras biológicas de saliva e soro, concordando com os resultados do ELISA de triagem.

Estudos realizados por Brooks e colaboradores (1985), para detecção de anticorpos anti - T. gondii, utilizou taquizoítos da cepa $\mathrm{RH}$ de camundongo swiss, do lavado peritonial para preparar o antígeno suspenso em salina, para a sensibilização do dot-ELISA, mostrando que existem várias vantagens para o dotELISA sobre outras técnicas como o ELISA, como o aumento da sensibilidade deste método, podendo detectar quantidades mínimas de antígeno (Araujo e Remington, 1980; Turunen, 1983; van Kanapen e Panggabean, 1977), como foi também comprovado em nossos estudos. 
O dot-ELISA dispensa o uso de equipamentos e foi considerado equivalente aos teste ELISA e IFA em estudo reportado na literatura (Pappas 1986) que foi importante para o desenvolvimento em nosso meio.

Com a possibilidade de trabalhar em campo muitos autores vem utilizando o dot-ELISA para o diagnóstico de rotavirus, utilizando amostras de fezes, também tendo altos resultados de sensibilidade $92 \%$ e $98 \%$ de especificidade (Anand et al. 2001) .

Estudos de Shukla (2008), utilizando ovos de Tanea taenaeformes do intestino de gato para preparação do antígeno suspenso em salina, para sensibilizar o dot-ELISA para o diagnóstico de neurocisticercose, os resultados foram de $88 \%$ de sensibilidade e $74 \%$ de especificidade, sendo inferior que nossos resultados no diagnóstico para toxoplasmose também utilizando o dot-ELISA como teste.

Nossos resultados do dot-ELISA foram superiores aos obtidos por Swarna e Parija (2008), na Equinococose, onde mostrou com antígeno HCF (hidatidose fluido antígeno) uma sensibilidade de $93,3 \%$ e especificidade de $70 \%$, já para o antígeno HPR (antígeno cisto protoscolex), foi de $86,6 \%$ de sensibilidade e $70 \%$ de especificidade. Na Leptospirose usando glicolipoproteína este teste não foi eficiente e apresentou inespecificidade (Blanco, 2007). A qualidade da preparação dos nossos antígenos e reagentes certamente contribuiu para maior eficiência de nossos ensaios.

Em Tripanosomiase africana, Coutioux e colaboradores (2005), utilizou a técnica dot-ELISA com os antígenos NF (neurofilamento) e Galc (galactocerebrosides), observou uma sensibilidade de 100\% e especificidade de $85,7 \%$, sendo a sensibilidade e especificidade muito parecida com o nosso do teste dot-ELISA antígeno salino. 
Nossos resultados para ELISA de captura mostraram uma discrepância em relação ao cromógeno utilizado, sendo o TMB o que apresentou a maior sensibilidade, aproximando-se dos resultados do dot-ELISA.

Estudos anteriores para detecção de lgG anti - T. gondii, já demonstravam o potencial do uso de teste "sanduíches" para aumentar a sensibilidade e especificidade do teste (Moleón et al., 1993).

Nossa prevalência para infecção por $T$. gondii foi menor que estudos realizados por Macre (2008) que obteve uma prevalência de $50 \%$ em crianças de zona urbana periférica. Ambos os estudos foram realizados em São Paulo, a grande diferença é que a nossa população de classe social elevada, com poder aquisitivo maior, enquanto a população estudada por Macre vivia na periferia, em um contato ambiental intenso podendo levar a uma exposição maior ao agente, devido à falta de saneamento básico e conhecimento prévio sobre a doença. A prevalência maior é encontrada em várias áreas do Brasil, em geral com maior exposição ambiental (Tenter, 2000), mas mesmo no Brasil variações regionais são muito frequentes (Guimarães et al., 1993). Estudos mais recentes tem mostrado uma menor incidência da doença (20\%) em universitários (informação verbal) ${ }^{1}$.

Muitos estudos corroboram com a idéia que quanto mais avançada for a idade dos voluntários, maior vai ser a taxa de positividade para toxoplasmose (Zarkovic et al., 2007). Este fato pode ser observado em nossos resultados das 100 amostras de salivas, onde a positividade da nossa população chegou a 19\% com um intervalo de confiança de $95 \%$ com uma variação de 11,8 - 28,1\%, sendo que nossa população tinha em média 19 anos.

1. Dados fornecidos por Jaqueline P. Rodrigues em debate, 2010. 
Estudo realizado em Beirute com 1371 soros de laboratórios e hospital, 2.145 soros de laboratórios privados (Bouhamdan et al., 2010), revelou uma prevalência de IgG anti- $T$. gondii de $55 \%$ e $67 \%$, respectivamente. A soro positividade mostrou significativa $(p<0,05)$ crescente com correlação com a idade avançada, por exemplo, de $9 \%$ a <ou = 5 anos para $78 \%$ e em $46-50$ anos, e $94 \%$ em> ou = 51 anos. Com base neste estudo de soro prevalência, a exposição à infecção por $T$. gondii é considerada alta entre a população libanesa e que aumenta com a idade avançada devido a uma maior exposição ao meio ambiente.

O grande problema em ter uma população com $80 \%$ de suscetíveis para a infecção com $T$. gondii, é o risco de mulheres contraírem a toxoplasmose durante a gravidez, com transmissão vertical dada a maior proporção de suscetíveis. Segundo Frenkel (1973), o risco fetal é semelhante quando tem uma transmissão anual de $1 \%$ ou $8 \%$ dada a idade fértil de 15 anos, aumentando entre estas prevalências.

Por essas razões, acreditamos que nossos ensaios dot-ELISA proteína A e ELISA de captura mostraram-se ser um teste de grande importância na saúde pública e factível para todos os tipos de laboratório, desde os de grande porte até os menores e de poucos recursos. Nossos resultados demonstram que o dot-ELISA proteína A e ELISA de captura são excelentes aliados como teste diagnóstico para triagem da toxoplasmose tanto em amostras de soro quanto em saliva, pois apresentaram altas taxas de sensibilidade e especificidade. Cada um dos ensaios tem suas características especificas como a utilidade em campo para o dot-ELISA ou a possibilidade de automação para ELISA de captura. O ensaio de dot-ELISA é qualitativo e por essas características se presta melhor a triagem de amostras para confirmação posterior pelo ELISA. 
A utilização de matrizes biológicas alternativas ao sangue vem ganhando cada vez mais importância na detecção de doenças e intoxicações, como aqui demonstrado. Neste contexto, a saliva não necessita de nenhum processo invasivo com rápida coleta para a detecção de anticorpos específicos. Isto nos possibilita trabalhar com populações protegidas pela sociedade como crianças, pela proteção familiar ; indígenas e populações culturalmente ou religiosamente diferentes; e outros grupos protegidos da sociedade. A utilização da saliva aumenta a participação em estudos voluntários e possibilita a coleta pelo próprio sujeito da pesquisa o que poderia até gerar pesquisas pelo correio, como já reportado pelo Orasure ${ }^{\circledR}$, pesquisando novas técnicas de diagnóstico para HIV (Wesolowski et al., 2006). Outra possibilidade é a construção de testes mais complexos com arranjos líquidos, que poderiam ser utilizados para a detecção de anticorpos para múltiplos antígenos, como para o controle vacinal de adolescentes, nossa próxima meta. Tudo isto mostra o potencial da saliva como uma fonte alternativa de IgG para detecção de infecção do $T$. gondii ou por outras afecções de diagnóstico semelhante. 


\section{CONCLUSÃO}

\subsection{Geral}

A saliva é uma alternativa eficiente para a demonstração de anticorpos lgG específicos anti T.gondii

\subsection{Específicos}

a) A saliva apresenta quantidades significativas de IgG que não tem relação com a proteína total salivar;

b) A melhor forma de coleta da saliva, que mantem a reatividade de $\lg G$ e diminui a contaminação com outras proteínas, é coleta até 5 minutos após enxague com enxaguante oral;

c) Foi possível padronizar ensaio imunoenzimático para detecção de anticorpos IgG anti T.gondii em amostras pareadas de soro e saliva de 20 voluntários;

d) Foi possível padronizar ensaio de dot-ELISA para detecção de anticorpos lgG anti T.gondii em amostras pareadas de soro e saliva de 20 voluntários;

e) Foi possível padronizar ensaio de captura de lgG por proteína A no suporte sólido (ELISA captura) com revelação com antígeno de T.gondii biotinilado, para detecção de anticorpos $\lg G$ anti T.gondii em amostras pareadas de soro e saliva de 20 voluntários;

f) Foi possível determinar a frequência de amostras de universitários com IgG anti-T.gondii, utilizando-se tanto a ELISA captura como o dot-ELISA. 


\section{REFERÊNCIAS BIBLIOGRÁFICAS}

Albert-Kiszely A, Pjetursson BE, Salvi GE, Witt J, Hamilton A, Persson GR,et al. Comparison of the effects of cetylpyridinium chloride with an essential oil mouth rinse on dental plaque and gingivitis - a six-month randomized controlled clinical trial. J Clin Periodontol. 2007 Aug;34(8):658-67.

Amato Neto V, Marchi CR. Toxoplasmose. In: Cinerman B, Cinermam S, editores. Parasitologia humana e seus fundamentos gerais. São Paulo: Atheneu; 1999. p. 157-78.

Amato Neto V, Medeiros, EAS, Levi GC, Duarte MIS. Toxoplasmose. 4.ed.São Paulo: Sarvier; 1995.

Ambroise-Thomas P. Emerging parasite zoonoses: the role of host-parasite relationship. Int J Parasitol. 2000 Nov;30(12-13):1361-7.

Amendoeiro, MRR, Da Costa T, Sapalding SM. Toxoplasma gondii Nicolle \& Manceaux, 1909 (Apicomplexa: Sarcocystidae) e a Toxoplasmose. Rev Souza Marques 1999; 1(1):15-35.

Anand T, Narasa Raju TA, Vishnu C, Venkateswar Rao LV, Sharma G. Development of Dot-ELISA for the detection of human rotavirus antigen and comparison with RNA-PAGE. Lett Appl Microbiol. 2001 Mar;32(3):176-80. 
Andrade GMQ, Carvalho AL, Carvalho IR, Nogueira MGS, Oréfice F. Congenital Toxoplasmosis - Treatment a prevention Guideline. Rev Me. Minas Gerais. 2004; 14(3):85-91.

Andrade GMQ, Tonelli E, Oréfice F. Toxoplasmose. In: Tonelli E, Freire LMS. Doenças infecciosas na infância e adolescência. 2. Ed. Rio de Janeiro. 2000, p. 1297-1339.

Angel S, Maero E, Blanco JC, Pzsenny V, Zala C, Gonzalez R, et al. Early diagnosis of toxoplasmic encephalitis in AIDS patients by dot blot hybridization analysis. J Clin Microbiol. 1992 Dec;30(12):3286-7.

Anthony CW. Disseminated toxoplasmosis in a liver transplant patient. J Am Med Womens Assoc. 1972 Nov;27(11):601-3.

Araujo FG, Remington JS. Antigenemia in recently acquired acute toxoplasmosis. J Infect Dis. 1980 Feb;141(2):144-50.

Archibald DW, Barr CE, Torosian JP, McLane MF, Essex M. Secretory IgA antibodies to human immunodeficiency virus in the parotid saliva of patients with AIDS and AIDS-related complex. J Infect Dis. 1987 Apr;155(4):793-6.

Bader TJ, Macones GA, Asch DA. Prenatal screening for toxoplasmosis. Obstet Gynecol. 1997 Sep;90(3):457-64. 
Bendayan M. Ultrastructural localization of insulin and C-peptide antigenic sites in rat pancreatic B cell obtained by applying the quantitative high-resolution protein Agold approach. Am J Anat. 1989 Jun-Jul;185(2-3):205-16.

Benjamini E, Coico R, Sunshine G. Imunologia. 4. ed. Rio de Janeiro: Guanabara Koogan, 2002.

Billingsley PF, Baird J, Mitchell JA, Drakeley C. Immune interactions between mosquitoes and their hosts. Parasite Immunol. 2006 Apr;28(4):143-53.

Blanco RM. Avaliação da glicolipoproteína como antígeno para sorodiagnóstico da Leptospirose. (dissertação) São Paulo: Universidade de São Paulo, Faculdade de Ciências Farmacêuticas; 2007.

Botterel F, Ichai P, Feray C, Bouree P, Saliba F, Tur Raspa R, et al. Disseminated toxoplasmosis, resulting from infection of allograft, after orthotopic liver transplantation:usefulness of quantitative PCR. J Clin Microbiol. 2002 May;40(5):1648-50.

Bouhamdan SF, Bitar LK, Saghir HJ, Bayan A, Araj GF. Seroprevalence of Toxoplasma antibodies among individuals tested at hospitals and private laboratories in Beirut. J Med Liban. 2010 Jan-Mar;58(1):8-11.

Bradford MM. A rapid and sensitive method for the quantitatiom of microgram quantities of protein utilizing the principle of protein-dye binding. Anal Biochem. $1976 ; 72: 248-54$ 
Brooks RG, Sharma SD, Remington JS. Detection of Toxoplasma gondii antigens by a dot-immunobinding technique. J Clin Microbiol. 1985 Jan;21(1):113-6.

Brown NJ, McKenzie S, Decker MD. Case report: fatal pulmonary toxoplasmosis following chemotherapy. Am J Med Sci. 1991 Sep;302(3):152-4.

Brown C, McLeod R. Mechanisms of survival of mice during acute and chronic Toxoplasma gondii infection. Parasitol Today. 1994 Aug;10(8):290-2.

Buxton D, Innes EA. A commercial vaccine for ovine toxoplasmosis. Parasitology. 1995; 110(11):11-6.

Camargo ME, Ferreira AW, Mimeo JR, Takiguti CK, Nakahara OS. Immunoglubulin $G$ and immunoglobulin $M$ enzyme - linked immunosorbent assay and defined toxoplasmosis serological patterns. Infect Immun. 1978;21(1): 55 - 8.

Castro FC, Castro MJBV, Cabral ACV, Filho G, Vitor RWA, Lana AMA, Andrade GMQ. Comparação dos métodos para diagnostic da toxoplasmose congenital. Rev Bras Ginecol Obstet. 2001; 23(5):277-82.

Chiappin S, Antonelli G, Gatti R, De Palo E. Saliva specimen: a new laboratory tool for diagnostic and bases investigation. Clin Chim Acta. 2007; 383:30-40.

Coelho JS, Soares IS, Lemos EA, Jimenez MCS, Kudó ME, Moraes SL, et al. A multianalyte dot - ELISA for simultaneous detection of malaria, Chagas disease, and syphilis - specific IgG antibodies. Diagn Microbiol Infect Dis. 2007, 58(2): 223 230. 
Coelho RAI, Kobayashi M, Carvalho LB. Prevalence of IgG antibodies specific to Toxoplasma gondii among blood donors in Recife, Northeast Brazil. Rev, Ins, Med, Trop, São Paulo, 2003; 45(4): 229 - 31.

Contreras CE, Pance A, Marcano N, González N, Bianco N. Detection of specific antibodies to Plamodium falciparum in blood bank donors from malaria - endemic and non - endemic areas of Venezuela. Am J Trop Med Hyg. 1999; 60(6): 948 - 53.

Courtioux B, Bisser S, M'belesso P, Ngoungou E, Girard M, Nangouma A., et al. Dot enzyme - linked immunosorbent assay for more reliable stanging of Patients with Human African trypanosomiasis. J Clin Microbiol. 2005; 43(9): 4789 -95.

Cutts FT, Brown DWG. The contribution of field tests to measles surveillance and control: A review of available methods. Rev Med Virol. 1995;5:35-40.

Cutts FT, Henao-Restrepo A, Olivé JM. Measles elimination: Progress and challenges. Vaccine. 1999;17:S47-52.

Dave J, Johnson A, Andrews N, Harford J, Balfour A, Tompkins D. Detection of toxoplasma - specific antiboby in human saliva using conventional assay. Serodiagn Immunother Infect Dis. 1996; 8, 195 - 199.

Deisenhofer, J. Crystallographic refinement and atomic model of a human Fc fragment and its complex with fragment B of protein A from Strephylococcus aureus at 2.9 - and $2.9-$ A resolution. Biochemistry. 1981; 20( 9): $2361-70$. 
de Oliveira SA, Siqueira MM, Brown DW, Litton P, Camacho LA, Castro ST, et al. Diagnosis of rubella infection by detecting specific immunoglobulin $\mathrm{M}$ antibodies in saliva samples: a clinic-based study in Niterói, RJ, Brazil. Rev Soc Bras Med Trop. $2000 ; 33(4): 335-9$.

Dinesh DS, Das P, Picado A, Davies C, Speybroeck N, Ostyn, et al. Long-lasting insecticidal nets fail at household level to reduce abundance of sandfly vector Phlebotomus argentipes in treated houses in Bihar (India) Trop Med Int Health. 2008;13:953-8.

Dubey JP. Advances in the life cycle of Toxoplasma gondii and comparison of infectivity of bradyzoites of the VEG strain Toxoplasma gondii to cats and mice. J. Parasitol. 2001; 87:215-9.

Dubey JP, Frenkei JK. Cyst-induced toxoplasmosis in cats. J Protozool. 1972; 19: 155-77.

Dubey JP, Katula AW, Sharar A, Andrews CD, Lindsay DS - Effect of high temperature on infectivity of toxoplasma gondii tissue cysts in pork. J Parasitol. $1990 ; 76: 201-4$

Dubey JP, Lindsay DS, Speer CA. Structures of Toxoplasma gondii Tachyzoites, Bradyzoites, Sporozoites and Biology and Development of Tissue Cysts. Clin Microbiol. 1998; 11( 2): 267-9. 
Dubey JP, Lago EG, Gennari SM, Su C, Jones JL. Toxoplasmosis in humans and animals in Brazil: high prevalence, high burden of disease, and epidemiology.Parasitology. 2012 Jul 10:1-50.

Dubey JP, Weige RM, Siegel AM, Thulliez P, Kitron UD, Mitchell MA, et al. Sources and reservoirs of Toxoplasma gondii infection on 47 swine farms in Illiniois. J Parasitol. 2003; 81: 723-9.

Eamsobhana P, Yoolek A, Punthuprapase P, Suvouttho S. A dot - blot ELISA comparable to immunoblot for the specific diagnostics of human parastrongyliasis. $\mathrm{J}$ Helminthol. 2004; 78: 287-91.

Endresen $\mathrm{C}$. The binding of protein $\mathrm{A}$ of immunoglobulin $\mathrm{G}$ and of Fab and Fc fragments. Acta Pathol Microbiol. 1979; 87C( 3): 185 - 89.

Feldman M, Plancarte A, Sandoval M, Wilson M, Flisser A. Comparison of two assays (EIA and EITB) and two samples (saliva and serum) for the diagnosis of neurocysticercosis. Trans R Soc Trop Med Hyg. 1990;84(4):559-62.

Ferreira AW, Ávila SLM. Diagnósticos laboratoriais das principais doenças infecciosas e auto-imune. 2.ed. Rio de Janeiro: Guanabara Koogan, 2001.

Filisetti D, Candolfi E. Immune response to Toxoplasma gondii: Ann Ist Super Sanita. 2004; 40(1):71-80.

Frenkel JK. Pathophysiology of toxoplasmosis. Parasitol. Today, 1988; 4(10):273-8.

Frenkel JK. Toxoplasma in and around us. Bio Science, 23: 343-2, 1973. 
Friedman MG. Radioimmunoassay for the detection of virus-specific IgA antibodies in saliva. J Immunol Meth. 1982; 54:203-11.

Gaddi PJ, Yap GS. Cytokine regulation of immunopathology in toxoplasmosis. Immunol Cell Biol. 2007;85(2):155-9.

Galisteo Jr AJ, Toxoplasmose gondii VS radiação ionizante: Imunidade humoral e celular em baços e intestinos de camundongos isogênicos imunizados com táquizoidos irradiados por Cobalto 60. (tese) São Paulo: IPEN- Instituto de Pesquisas Nucleares, Universidade de São Paulo; 2008.

Garcia MMA, Amorim MN, Viana LG, Garcia TC, Watz N, Rabello AL. Detection of anti - Schitosoma antibodies in oal fluids. Mem Inst Oswaldo Cruz. 1995; 90: 513.

Glasner PD, Silveira C, Kruszon-Moran D, Martins MC, Burnier Júnior M, Silveira S, et al. An unusually high prevalence et ocular toxoplasmosis in southern Brazil. Am J Ophthalmol. 1992;15;114(2):136-44.

Gleeson M, Pyne DB. Special feature for the Olympics: effects of exercise on the immune system: exercise effects on mucosal immunity. Immunol Cell Biol. 2000;78:536-44.

Granade TC, Phillips SK, Paekh B. Oral fluid as a specimen for detection and confirmation of antibodies to human immunodeficiency virus type I. Clin Diagn Lab Immunol. 1995;2: 395-9. 
Granström M, Wretlind B, Markman B, Cryz S. Enzyme-linked immunosorbent assay to evaluate the immunogenicity of a polyvalent Klebsiella capsular polysaccharide vaccine in humans. J Clin Microbiol. 1988;26(11):2257-61.

Goldman AS, Goldblum RM. Deficiências primárias da imunidade humoral. Clin Pediátr Am Norte. 1977; 24:277-91.

Gordis EB, Grangier DA, Susman EJ, Trickett PK. Asymmetry between salivary cortisol and alpha-amylase reactivity to stress: relation to aggressive behavior in adolescents. Psychoneu roendocrinology . 2006;31:976-87.

Gorgun A, Knight DR, Wright GD. Use of oral mucosal neutrophil counts to detect the onset and resolution of profound neutropenia following high-dose myelosuppressive chemotherapy. Am J Hematol. 2003;72:13-9.

Guimarães AC, Kawarabayashi M, Borges MM, Tolezano JE, Andrade Júnior HF. Regional variation in toxoplasmosis seronegativity in the São Paulo metropolitan region. Rev Inst Med Trop Sao Paulo. 1993;35(6):479-83.

Haeckel R. Procedures for saliva sampling. J Clin Chem Clin Biochem. 1989; 27( 4):246-247.

Hajeer AH, Balfour AH, Mostratos ANN, Crosse B. Toxoplasma gondii: detection of antibodies in human saliva and serum. Parasite Immunol. 1994;16:43-50.

Hakes TB, Armstrong D. Toxoplasmosis: problems in diagnosis and treatment. Cancer. 1983;52:1535-40. 
Helmerhorst EJ, Oppenheim FG. Saliva: a dynamic proteome. J Dent Res. 2007 86(8):680-9.

HillI DE, Dubey JP. Toxoplasma gondii: transmission, diagnosis and prevention. Clin Microbiol Infect. 2002;8:634-40.

Hiil DE, Sreekumar C, Dubey JP. Biology and epidemiology of Toxoplasma gondii in man and animals. Anim Health Res Rev. 2005;6(1):41-61.

Hiramoto RM, Galisteo JR AJ, Nascimento N, Andrade Jr HF. 200 Gy sterilised Toxoplasma gondii tachyzoites maintain metabolic functions and mammalian cell invasion, eliciting cellular immunity and cytokine response similar to natural infection in mice. Vaccine, 2002; 20(16):2072-2081.

Howe DK, Sibley LD. Toxoplasma gondii comprises three clonal lineages: correlation of parasite genotype with human disease. J.Infect.Dis. 1995;172(6): 1561 -6 .

Humphrey S, Willianson R. A review of saliva: Normal composition, flow and function. J. Phosthet Dent. 2001;85(2):162-9.

Jacobs L, Lunde M. A hemagglutination test toxoplasmosis. J. Parasitol.1957, 43: 380-14, apud. Amato Neto V, Medieros EAS, Levi GC, Duarte MIS. Toxoplasmose. 4 ed. São Paulo: Sarvier, 1995. 154p.

Janeway CA Jr, editors. Immunobiology: the immune system in health and disease. 5th ed. New York: Garland Science; 2001. 
Janku J. Pathogenesis and pathologic anatomy of coloboma of macula lutea in eye of normal dimensions, and in microphtalmic eye, with parasites in the retina. Cas. Lek. Cesk, 1923; 62:1021-27.

Jeganathan S, Ufomata D, Hobkirk JA, Ivanyi L. Immunoglobulin A1 and A2 subclass of salivary antibodies to Candida albicans in patients with oral candidiasis. Clin Exp Immunol, 1987;70(2):316-21.

Johansson S G, Inganas M. Interation of polyclonal human $\lg E$ with protein A from Straphylococcus aureus. Immunol Rev. 1978; 41: 248-60.

Jones JL, Lopes A, Wilson M, Schilkin J, Biggsl R. Congenital Toxoplasmosis: a review. Obst Gynecol Surv. 2001;56( 5):296-305.

Kaufman E, Lamster IB. The diagnostic applications of saliva-a review. Crit Rev Oral Biol Med. 2002;13(2):197-212.

Kiijlstrall A, Jongert E. Control of the risk of human toxoplasmosis transmitted by meat. Int J Parasitol. 2008;38(12):1359-70.

Kraus FW, Konno J. Antibodies in saliva. Ann N Y Acad Sci. 1963;106:311-29.

Krusne S, Dummer JS. Self-limited Toxoplasma parasitemia after liver transplantation. J Exp Med. 1987; 44:457-8. 
Laemli UK. Cleavage of structural proteins during the assembly of the head of bacteriophage T4. Nature. 1970; 227:680-5.

Lamm ME. Interactions of antigens and antibodies at mucosal surfaces. Annu Rev Microbiol. 1997;51:311-40.

Lamster IB, Ahlo JK. Analysis of gingival crevicular fluid as applied to the diagnosis of oral and systemic diseases. Ann N Y Acad Sci. 2007 Mar;1098:216-29

Langone JJ. Protein A from Staphylococcus aureus and related immunoglobulin receptors produced by streptococci and pneumococci. Adv Immunol, 1982;32:157 252.

Lawrence H. Salivary marker of systemic disease: noninvasive diagnosis of disease and monitoring of general health. J Can Dent Assoc 2002; 68(3):170-4.

Lee Yu-Hsiang, Wong David T. Saliva: An emerging biofluid for early detection of diseases. Am J Dent. 2009; 22(4): 241-8.

Lin YH, Wang Y, Loua A, Day GJ, Qiu Y, Nadala EC Jr, et al. Evaluation of a new hepatitis B virus surface antigen rapid test with improved sensitivity. J Clin Microbiol. 2008;46(10):3319-24 .

Lindmark R, Thorén-Tolling K, Sjöquist J. Binding of immunoglobulins to protein A and immunoglobulin levels in mammalian sera. J Immunol Methods. 1983 Aug $12 ; 62(1): 1-13$. 
Loyola AM, Durighetto AF Jr, Silva DA, Mineo JR. Anti-Toxoplasma gondii immunoglobulins $A$ and $G$ in human saliva and serum. J Oral Pathol Med. $1997 ; 26(4): 187-91$.

Machado RZ. Erliquiose canina. In: XIII Congresso Brasileiro de Parasitologia Veterinária \& I Simpósio Latino - Americano de Ricketisioses, Ouro Preto, MG, 2004. P. 53-7. (Revista Brasileira de Parasitologia Veterinaria; v.13; supl.1)

Macre MS. Padronização e aplicação de ensaio imunoenzimático paradetecção de anticorpos IgG contra Toxoplasma gondii na saliva de escolares. (tese), São Paulo: Instituto de Ciências Biomédicas, Universidade de São Paulo, 2008.

Malamud D, Nagashunmugam T, Davis C, Kennedy S, Abrams WR, Kream, R, et al. Inhibition of HIV infectivity by human saliva. Oral Dis. 1997;3(1):58-63.

Mandel ID. Salivary diagnosis: more than a lick and a promise. J Am Dent Assoc. 1993;124:85-7.

Matsumoto, T.K. Amastigota do Trypanosoma cruzi utilização nas técnicas de DotELISA e Imunofluorescência para a detecção de anticorpos IgG, IgM e IGA na doença de chagas.(dissertação). São Paulo: Faculdade de Ciências Farmacéuticas, Universidade de São Paulo; 1990.

McGregorC , Fleck D, Nagington J. \& cols. - Disseminated toxoplasmosis in cardiac transplantation. J Clin Pathol. 1984;37:74-7. 
Mead PS, Slutskerl L, Dietz V, McCaig LF, Bresee JS, Shapiro C, et al. Food related illness and death in the United States. Emerg Infect Dis. 1999;5(5):607-25.

Meireles, L.R. Estudos das fontes de Infecção da Toxoplasmose humana em diferentes localidades do Estado de São Paulo. (dissertação), São Paulo: Instituto de Ciências Biomédicas, Universidade de São Paulo, 2001.

Meireles LR, Galisteo AJ, Pompeu E, Andrade Jr HF. Toxoplasma gondii spreading in na urban área evaluated by seroprevalence in free-living cats and dogs. Trop Med, Int Health, 2004;9:876-81.

Meurman JH, Collin HL, Niskanen L, Töyry J, Alakuijala P, Keinänen S, et al. Saliva in non-insulin-dependent diabetic patients and control subjects: The role of the autonomic nervous system. Oral Surg Oral Med Oral Pathol Oral Radiol Endod. 1998 Jul;86(1):69-76.

Michaels MG, Wald ER, Fricker FJ, del Nido JP, Armitage J. Toxoplasmosis in pediatric recipients of heart tranplants. Clin Infect Dis, 1992;14:847-51.

Mioranza SL. Desenvolvimento de teste imunocromatográfico para detecção de anticorpos IgG anti- Toxoplasma gondii. (tese). São Paulo, Instituto de Ciências Biomédicas, Universidade de São Paulo, 2009.

Moleón I, González T, Machín R, Molina JR, García CA. Capture immunoassay for the detection of human IgG against Toxoplasma gondii protein P30. Rev Latinoam Microbiol. 1993 Jul-Sep;35(3):309-14. 
Moura L, Bahia-Oliveira LM, Wada MY, Jones JL, Tuboi SH, Carmo EH, et al. Waterborne toxoplasmosis, Brazil, from field to gene. Emerg Infect Dis. 2006 Feb;12(2):326-9.

Morris M, Cohen B, Andrews N, Brown D. Stability of total and rubella-specific IgG in oral fluid samples: the effect of time and temperature. J Immunol Methods. 2002 Aug 1;266(1-2):111-6.

Morris-Cunnington MC, Edmunds WJ, Miller E, Brown DW. A novel method of oral fluid collection to monitor immunity to common viral infections. Epidemiol Infect. 2004 Jan;132(1):35-42.

Morris-Cunnington MC, Edmunds WJ, Miller E, Brown DW. A population-based seroprevalence study of hepatitis A virus using oral fluid in England and Wales. Am J Epidemiol. 2004 Apr 15;159(8):786-94.

Mortimer PP, Parry JV. Non-invasive virological diagnosis: are saliva and urine specimens adequate substitutes for blood? Rev Med Virol. 1991;1:73-8.

Moura L, Bahia-Oliveira LMG, Wada MY, Jones JL, Tuboi SH, Carmo EH, et al. Waterborne Toxoplasmosis: Brazil, from field to gene. Emerg Infect Dis 2006;12:326-329.

Munday BL. Bovine toxoplasmosis: experimental infections. Int J Parasitol. 1978 Aug;8(4):285-8.

Nair PNR, Schroeder HE Duct-associated lymphoid tissue (DALT) of minor salivary glands and mucosal immunity. Immunology. 1986; 57:171-180. 
Navazesh M. Methods for collecting saliva. Ann NY Acad Sci. 1993; 20:72-7.

Nicolle C, Manceaux C. Sur une infection à corps de Leishman ( ou organisms voisins) du gondii. C R Hebd Seances Acad Sci. 1908;147:763 -6.

Niedbala RS, Kardos KW, Fritch D, Kunsman KP, Blum KA, Newland GA, et al. Passive cannabis smoke exposure and oral fluid testing. II. Two studies of extreme cannabis smoke exposure in a motor vehicle. J Anal Toxicol. 2005;29:607-15.

Nieuw Ameragen AV, Bolscher JGM, Veerman ECI. Salivary protein: protective and diagnostic value in cariology? Caries Res. 2004;38:247-53.

Nokes DJ, Nigatu W, Abebe A, Messele T, Dejene A, Enquselassie AF, et al. A comparison of oral fluid and serum for the detection of rubella-specific antibodies in a community study in Addis Ababa, Ethiopia. Trop Med Int Health. 1997;3:258-67.

Pappas MG, Lunde MN, Hajkowski R, McMahon J. Determination of IgM and IgG antibodies to Toxoplasma using the IFA test, ELISA, and Dot-ELISA procedures. Vet Parasitol, 1986;20:31-42.

Parisi MR, Soldini L, Di Perri G, Tiberi S, Lazzarin A, Lillo FB. Offer of rapid testing and alternative biological samples as practical tools to implement HIV screening programs. New Microbiol. 2009 Oct;32(4):391-6. 
Parry JV, Perry KR, Mortimer PP. Sensitive assay for viral antibodies in saliva: an alternative to test on serum. Lancet. 1987;2:72-5.

Pavie J, Rachline A, Loze B, Niedbalski L, Delaugerre C, Laforgerie E, Plantier JC, et al. Sensitivity of five rapid HIV tests on oral fluid or finger-stick whole blood: a real-time comparison in a healthcare setting. PLoS One. 2010 Jul 19;5(7):e11581.

Pena HF, Gennari SM, Dubey JP, SU C. Population structure and Mouse-virulence of Toxoplasma gondii in Brazil. Int J Parasitol. 2008; 38(5):561-9.

Perry KR, Brown DWG, Parry JV. Detection of measles, mumps, and rubella antibodies in saliva using antibody capture radioimmunossay. J Med Virol. 1993;40: $235-40$.

Pil K, Esposito FM, Verstraete A. External quality assessment of multi-analyte chromatographic methods in oral fluid. Clin Chim Acta. 2010;411(15-16):1041-5.

Pinkerton H, Weinman D. Toxoplasma infection in man. Arch. Pathol. 1940;30:37492 Apud. Amato Neto V, Medieros EAS, Levi GC, Duarte MIS. Toxoplasmose. 4. ed. São Paulo: Sarvier;1995. 154p.

Pinto PL, Kanamura HY, Silva RM, Rossi CRN, Andrade JR HF, Amato Neto V. Dot -ELISA for the detection of IgM and IgG antibobies to Schistosoma mansoni worm and egg antigens, associated with egg excretion by patients. Rev. Ins. Med. Trop. São Paulo, 1995;37(2):109-15. 
Pires AL. Estudos do perfil salivar e sérico em gestantes e não gestantes. (dissertação). Brasilia: Universidade de Brasília. Faculdade de Ciências da Saúde. Departamento de Odontologia; 2008.

Ponce C, Ponce E, Vinelli E, Montoya A, de Aguilar V, Gonzalez A, et al.Validation of a rapid and reliable test for diagnosis of chagas' disease by detection of Trypanosoma cruzi-specific antibodies in blood of donors and patients in Central America. J Clin Microbiol. 2005 Oct;43(10):5065-8.

Quoilin S, Hutse V, Vandenberghe H, Claeys F, Verhaegen E, De Cock L, et al. A population-based prevalence study of hepatitis A, B and C virus using oral fluid in Flanders, Belgium. Eur J Epidemiol. 2007;22(3):195-202.

Raí GP, Zachariah K, Sharma R, Phadake S, Belapurkar KM. Development of a sandwich dot - enzyme linked immunosorbent assay for Streptococcus pneumoniae antigen detection in cerebrospinal fluid. Comp Immunol Microbiol Infec Dis, 2004; 27(3):217-23.

Rantonen P. Salivary flow and composition in healthy and diseased adults [Academic Dissertation]. Helsinki: Faculty of Medicine, University of Helsinki; 2003.

Rantonen PJ, Meurman JH. Viscosity of whole saliva. Acta Odontol Scand. 1998 Aug;56(4):210-4.

Rey L. Parasitologia. 2ª Ed. Rio de Janeiro: Guanabara Koogan; 1991. 
Remington JS, MCLeod R, Desmonts G. Toxoplasmosis. In: Remington JS, Klein JO, eds. Infectious diseases of the fetus \& newborn infant. Philadelphia: Saunder; 1995. $140-67$.

Reynolds ES, Walls KV \& Pfeifer RI. Generalized toxoplasmosis after following renal transplantation. Arch Intern Med.1966;118:401-5.

Ryning FW, McLeard R, Maddox JC \& cols. - Problabe transmission of Toxoplasma gondii by organ transplantation. Ann Intern Med. 1979;90:47-9.

Sabin AB. Toxoplasmic encephalitis in children. J Amer Med Ass. 1941;116:801-7.

Sabin $A B$, Feldman $H$. Dyes as microchemical indicators of a new phenomenon affecting a protozzon parasited (Toxoplasma). Science. 1948;108:660-3.

Santos MM, Garcia TC, Orsini M, Disch J, Rabello A. Oral fluids for the immunodiagnosis of Schistosoma mansoni infection. Transactions of the Royal Society of Tropical Medicine and Hygiene.2000;94:289-92.

Sharma SD. Immunology of toxoplasmosis. In: Wyler DJ. Modern parasite biology: cellular, immunological and molecular aspects. Oxford:Freeman;1990.p.184-99.

Shukla N, Husain N, Agarwal GG, Husain M. Utility of cysticercus fasciolaris antigen in dot-ELISA for the diagnosis of neurocysticercosis. Indian J Med Sci. 2008;62( 6): 222-7. 
Smith DJ, Joshipura K, Kent R, Tauman MA. Effect of age on immunoglobulin content and volume of human labial gland saliva. J Dent Res. 1992;71(12):1891-4.

Singh MP, Dubey ML, Sud A, Malla N. Antibody response to Toxoplasma gondii in saliva samples from human immunodeficiency virus - infected patients. Br J Biomed Sci. 2005;62(2):81-4.

Sparkes AH. Toxoplasmosis en el gato y en el hombre. In: $23^{\circ}$ Congresso de La Asociación Mundial de Medicina Veterinaria de Pequenos Animales, Buenos Aires. 1998, Anais: Asociación Mundial de Medicina Veterinaria de Pequeños Animales, 1998, Buenos Aires:p.415-417.

Splendore A. Un nuovo protozoa parasita de conigli incontrata nelle lesioni anatomeche de' une malattia che ricorda in molti punti il kala-azar dell'uomo.Nota preliminaire. Rev Soc Sci. São Paulo, 1908; 3(10-12):109-12.

Streckfus CF, Bigler LR. Saliva as a diagnostic fluid. Oral Dis. 2002;8(2):69-76.

Stroehle A, Schmid K, Heinzer I, Naguleswaran A, Hemphill A. Performace of a western immunoblot assay to detect specific anti - toxoplasma gondii $\lg G$ antibodies in human saliva. J Parasitol. 2005;91(3):561-3.

Swarna SR , Parija SC. Dot-ELISA for evaluation of hydatid cyst wall, protoscoleces and hydatid cyst fuid antigens in the serodiagnosis of cystic echinococcosis. Rev Inst Med Trop São Paulo. 2008;50(4):233-6. 
Takei T, Aono W, Nagashima S, Yoshida T, Hashida T, Sobue S, et al. Change of salivary $\lg A$ secretion and caries development in irradiated rats. J Dent Res. 1994;73:1503-8.

Tenovou JO, Lagerlof F. Saliva. In: Thylstrup A, Fejerskov O. Cariologia clínica. 2. ed. São Paulo: Livraria Editora Santos; 1995. p. 17-43.

Tenter AM, Heckeroth AR, Weiss LM. Toxoplasma gondii: from animals to humans. Int J Parasitol. 2000;30(12-13):1217-58.

Teutsch SM, Juranek DD, Sulzer A, Dubey JP, Sikes RK. Epidemic toxoplasmosis associated with infected cats. N Engl J Med. 1979 Mar 29;300(13):695-9.

Turunen HP. Detection of soluble antigens of Toxoplasma gondii by a four-layer modification of an enzyme immunoassay. J Clin Microbiol.1983;17:768 -73.

Van Knapen F, Panggabean SO. Detection of circulating antigen during acute infections with Toxoplsma gondii by enzyme - linked immunosorbent assay. J Clin Microbiol.1977;6:545-7.

Varella IS, Wagner MB, Darela AC, Nunes LM, Muller RW. Seroprevalence of toxoplasmosis in pregnant women. J Pediatr Rio J. 2003;79(1):69-74.

Venkatesan P, Wakelim D. ELISAs for parasitologists: or lies, dammed lies and ELISAs. Parasitol Today. 1993;9(6):228-32. 
Verwey W F. A type-specific antigen protein derived from the staphylococcus. J Exp Med.1940;71:635-44.

Vyse AJ, Brown DW, Cohen BJ, Samuel R, Nokes DJ. Detection of rubella virusspecific immunoglobulin $G$ in saliva by an amplification-based enzyme-linked immunosorbent assay using monoclonal antibody to fluorescein isothiocyanate. $\mathrm{J}$ Clin Microbiol. 1999;37(2):391-5.

Wallace GD. Serological and epidemiologic observation on toxoplasmosis on three Pacific atolls. Am J Epidemiol. 1969;90:103-11.

Walton BC, Benchoff BM, Brooks WH. Comparison of the indirect fluorescent antibody test and methylene blue dye test for the detection of antibodies to Toxoplasma gondii. Am J Trop Med Hyg.1966;15:149-52.

Wang Z, Xue C, Lou W, Zhang X, Zhang E, Wu W, Shen G. Non-invasive immunodiagnosis of Schistosomiasis japonica: the detection of specific antibodies in saliva. Chin Med J (Engl). 2002;115(10):1460-4.

Wesolowski LG, MacKellar DA, Facente SN, Dowling T, Ethridge SF, Zhu JH,et al. Post-marketing Surveillance Team. Post-marketing surveillance of OraQuick whole blood and oral fluid rapid HIV testing. AIDS. 2006 ;20(12):1661-6.

Wong DT. Salivary diagnostics for oral cancer. J Calif Dent Assoc.2006,34(4):303-8.

Wright DG, Meierovics AI, Foxley JM. Assessing the delivery of neutrophils to tissues in neutropenia. Blood. 1986;67:1023-30. 
Yang J, Jin M, Chen J, Yang Y, Zheng P, Zhang A, et al. Development and evaluation of an immunochromatographic strip for detection of Streptococcus suis type 2 antibody. J Vet Diagn Invest. 2007 Jul;19(4):355-61. 
ANEXOS 
ANEXO A

UNIVERSIDADE DE SÃO PAULO

INSTITUTO DE MEDICINA TROPICAL DE SÃO PAULO

Av. Dr. Enéas de Carvalho Aguiar, 470

CEP 05403-000 - São Paulo - Brasil

e-mail: cpq-imt@usp.br

Telefone:(55-11)3061-7193 e 3061-8650 FAX: (55-11) 3064-5132 e 3062-2174

São Paulo, 30 de junho de 2010.

IImo.(a) Sr.(a)

Dr. (a) Heitor Franco de Andrade Junior

(aos cuidados de Barbara Fialho Carvalho Sampaio)

Em reunião na presente data, a Comissão de Pesquisa e Ética e Comissão de Ética no Uso de Animais do Instituto de Medicina Tropical de São Paulo, analisou e aprovou, no que diz respeito aos aspectos de natureza da ética em experimentação animal, o projeto de pesquisa classificado sob número CPE-IMT 2010/067 e intitulado "Desenvolvimento de ensaios sorológicos para otimização da detecção de especificidade de IgG anti-T.gondii em saliva humana", sob responsabilidade do Dr. Heitor Franco de Andrade Junior. O projeto deverá ser submetido à Comissão de Ética para Análise de Projetos de Pesquisa - CAPPESq.

Atenciosamente

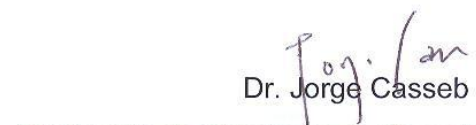

Presidente da Comissăo de Pesquisa e Ética do IMT

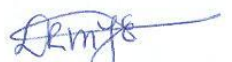

Dra. Luciana Regina Meireles Jaguaribe Ekman

Coordenadora da Comissão de Ética no Uso de Animais 
ANEXO B

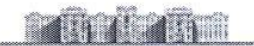 \\ MEDICINA \\ TSP \\ COMITÊ DE ÉTICA EM PESQUISA}

O Comitê de Ética em Pesquisa da Faculdade de Medicina da Universidade de São Paulo, em sessão de 09.02.2011, APROVOU o Protocolo de Pesquisa $\mathrm{n}^{0} \mathbf{0 3 1 / 1 1}$ intitulado: " Desenvolvimento de Ensaios Sorológicos para Otimização da Detecção de Especificidade de IgG anti - T. gondii em Saliva Humana." e seus anexos, apresentado pelo Instituto de Medicina Tropical.

Cabe ao pesquisador elaborar e apresentar ao CEP-FMUSP, os relatórios parciais e final sobre a pesquisa.

Pesquisador (a) Responsável: Heitor Franco de Andrade Junior

Pesquisador (a) Executante: Barbara Fialho Carvalho Sampaio

CEP-FMUSP, o9 de fevereiro de 2011.

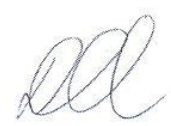

Prof. Dr. Daniel Romero Muñoz

Vice-coordenador

Comitê de Ética em Pesquisa

Comitê de Ética em Pesquisa da Faculdade de Medicina da Universidade de São Paulo Av. Dr. Arnaldo , 455 - Instituto Oscar Freire $1^{\circ}$ andar CEP 01246903 - Fone : 3061-8004 mail: cep.fmusp@hcnet.usp.br 


\section{ANEXO C \\ TERMO DE CONSENTIMENTO LIVRE E ESCLARECIDO}

\section{ESTUDO: Desenvolvimento de Ensaios Sorológicos para Otimização da Detecção de Especificidade de IgG anti - T. gondii em Saliva Humana}

Você está sendo convidado (a) a participar do projeto de pesquisa acima citado. $\mathrm{O}$ documento abaixo contém todas as informações necessárias sobre a pesquisa que estamos fazendo. Sua colaboração neste estudo será de muita importância para nós, mas se desistir a qualquer momento, isso não causará nenhum prejuízo a você.

$\mathrm{Eu}$, portador da Cédula de identidade, RG , e inscrito no $\mathrm{CPF} / \mathrm{MF}$ nascido(a) em l 1

abaixo assinado(a), concordo de livre e espontânea vontade em participar como voluntário(a) do estudo "Desenvolvimento de Ensaios Sorológicos para Otimização da Detecção de Especificidade de IgG anti - T. gondii em Saliva Humana" Eu , Declaro que obtive todas as informações necessárias, bem como todos os eventuais esclarecimentos quanto às dúvidas por mim apresentadas.

Estou ciente que:

I) $\quad$ estudo se faz necessário para que se possam descobrir as possíveis causas da doença denominada "Toxoplasmose";

II) Serão feitas 1 coleta de $5 \mathrm{ml}$. de saliva, no período/intervalo de..1/1..(dias/meses);

III) Essa (s) coleta(s) serão feitas apenas para este estudo e em nada influenciará (influenciarão) o meu tratamento; não vai (vão) me curar; não vai (vão) me causar nenhum problema; 
IV) A participação neste projeto não tem objetivo de me submeter a um tratamento, bem como não me acarretará qualquer ônus pecuniário com relação aos procedimentos médico-clínico-terapêuticos efetuados com o estudo ;

V) Tenho a liberdade de desistir ou de interromper a colaboração neste estudo no momento em que desejar, sem necessidade de qualquer explicação;

VI) A desistência não causará nenhum prejuízo à minha saúde ou bem estar físico. Não virá interferir no atendimento ou tratamento médico;

VII) Os resultados obtidos durante este ensaio serão mantidos em sigilo, mas concordo que sejam divulgados em publicações científicas, desde que meus dados pessoais não sejam mencionados;

VIII) Caso eu desejar, poderei pessoalmente tomar conhecimento dos resultados, ao final desta pesquisa

( ) Desejo conhecer os resultados desta pesquisa.

( ) Não desejo conhecer os resultados desta pesquisa.

IX) Concordo que o material poderá ser utilizado em outros projetos desde que autorizado pela Comissão de Ética deste Instituto e pelo responsável por esta pesquisa.

( ) Sim ou ( ) Não

São Paulo, de de 2010.

( ) Paciente / ( ) Responsável

Testemunha 1 :

Nome / RG / Telefone

Testemunha 2 :

Nome / RG / Telefone 
Responsável pelo Projeto:

Prof. Dr. Heitor Franco de Andrade Júnior - CRM 24325

Telefone para contato: 11 - 30617010 


\section{ANEXO D}

\section{FRENTE DO FOLDER}

\section{TOXOPLASMOSE}

NASESCOLAS
1.- os gatos têm um papel im-

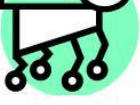
portante na transmissão da toxoplasmose, porque elíminam o parasita nas fezes. Estes parasitas, no meío verduras, legumes $e$

de material educativo sobre as formas de transmissão e prevenção da doença.

\section{O QUEÉ}

\section{TOXOPLASMOSE?}

É uma doença causada por um parasita bem pequeno chamado Toxoplasma gondii, que, no microscópio, tem forma parecida com a do desenho ao lado. Todos os animais de sangue quente como os mamiferos (incluindo o homem) e as aves podem adquírír esta doença. ambiente, contami-q nam a agua, frutas, a pastagem, transmitindo a doença para o homem $e$ on tros animais. Nestes animais, o parasita fica alojado na carne.

\section{COMO SE PEGA A TOXOPLASMOSE?}
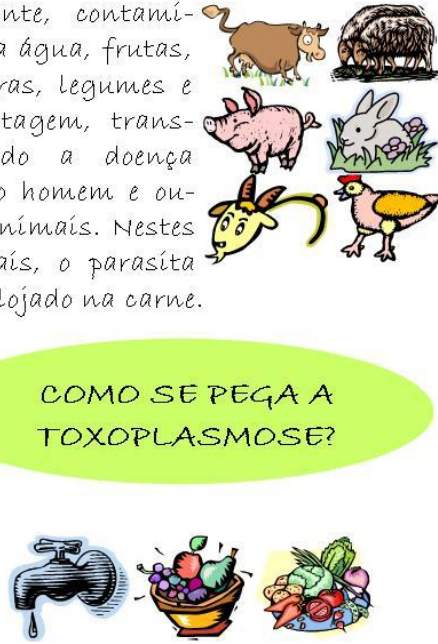

- Através da ingestão de agua, verduras, frutas e legumes contaminados com o parasita.

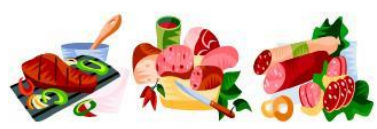

- ingestão de carne crua ou mal cozida

- Quando a mamãe adquire a doença durante a gravidez, transmitindo o parasita para o nenê. contendo o agente.

\section{QUAIS SAOOOS SINTOMASDA TOXOPLASMOSE?}

Em pessoas saudaveis, a doença passa despercebida porem, às vezes, da febre. aumento dos gânglíos do pescoco e problemas na visão, mas cura sozinha.

Em pacientes com outras doenças, como é o caso dos aídéticos, a toxoplasmose $\varepsilon$ grave e pode matar.

Quando adquirido durante a gravidez, o parasita pode atingir o nenê, causando cegueira e deficiêncía mental grave.

\section{A TOXOPLASMOSE}

TEM CURA?

Sim, existe tratamento eficiente, e quanto mais rapido for iniciado, menores serão os danos, príncipalmente para o nenê. Todas as gestantes devem procurar um posto de saúde para fazer o pré-

- natal e realizar exames de rotina entre eles, o $\therefore$ diagnóstico para toxoplasmose. 


\section{ANEXO E}

\section{VERSO DO FOLDER}

COMO EVITAR A DOENÇA?

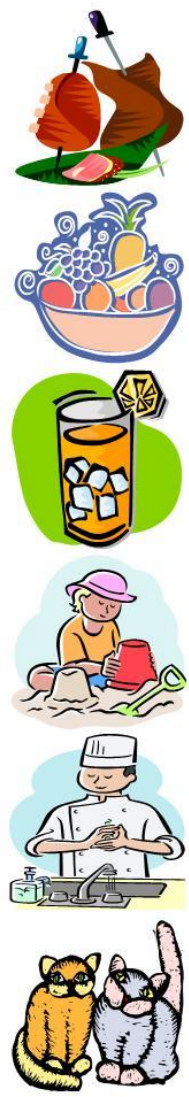

- Não ingerír carne crua ou mal cozida.

- Lavar muito bem as frutas, verduras elegumes;

- só ingerir agua filtrada ou fervida:

- Evitar que crianças entrem em contato com tanques de areía contaminados com fezes de gatos;

- Lavar as mãos antes de manipular os alimentos;

- Não tenha medo de ter gatos em casa, poís eles são ótimos companheiros. Apenas, evite entrar em contato com as fezes destes animais, para prevenir doenças como a toxoplasmose. vocêsabia que através da salíva é possível saber se uma pessoa já

foi infectada pelo parasita?

- Na nossa saliva exístem anticorpos que - são produzidos durante a infecção, por isso, - através da pesquisa destes anticorpos, e pos- sivel saber se você ja entron em contato com - oparasíta.

- Não fique preocupado, caso você tenha anticorpos, poís isto só indica que ganhou a guerra contra o Toxoplasma.

- Lembre-se, doar saliva não dói, e com isto você nos ajuda saber a prevalêncía da infecção em crianças da sua idade, contríbuíndo para o controle da doença.

Instituto de Medicina Tropical de Sâo Paulo Maiores informaçöes: Tel. (11) 30667010 Heitor, Miriam e Luciana ou no nosso e-maíl: proto.imt@usp.er

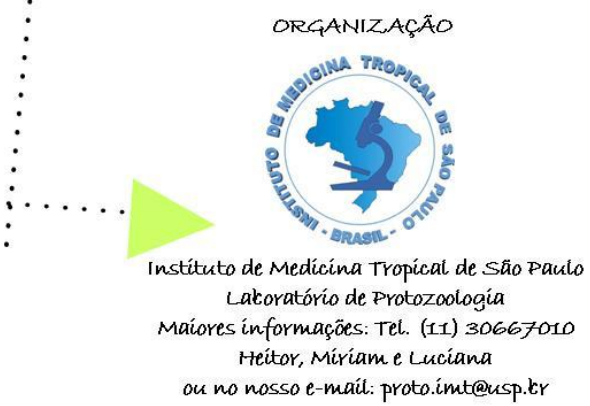
Lakoratório de Protozoología

\section{IMTSP-USP}

$\because$

$:$

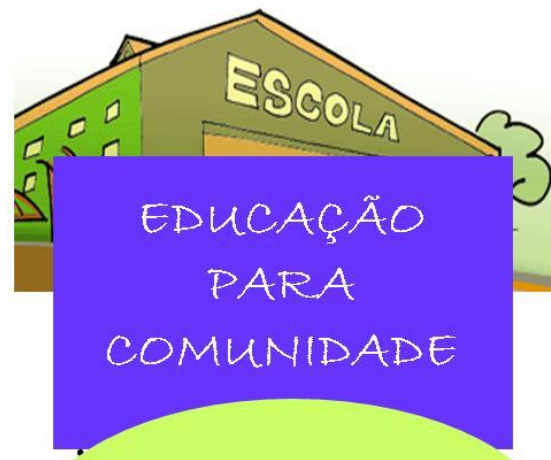

TOXOPLASMOSE

NAS ESCOLAS

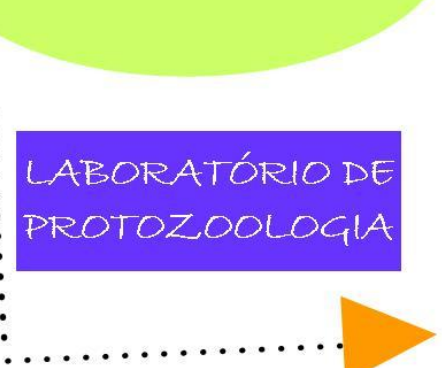


ANEXO F 
CMI CLINICAL MICROBIOLOGY

\section{Saliva as a source of anti-Toxoplasma gondii IgG for enzyme immunoassay}

\begin{tabular}{|r|l|}
\hline Journal: & Clinical Microbiology and Infection \\
\hline Manuscript ID: & CLM-12-4881 \\
\hline Manuscript Type: & Original Article \\
\hline Date Submitted by the Author: & 30 -Jul-2012 \\
\hline Key Words: & Andrade Jr., Heitor; Universidade de São Paulo, IMTSP \& FMUSP \\
\hline & $\begin{array}{l}\text { Toxoplasmosis that affects about one billion people worldwide is usually } \\
\text { asymptomatic, despite ocular disease and severe and lethal disease in } \\
\text { fetuses, AIDS patients and transplant recipients. Serology is the main } \\
\text { approach for diagnosis and incidence determination is a difficult task due to } \\
\text { high prevalence in most countries. Incidence studies are feasible in } \\
\text { children but this age group is protected and difficult to approach by } \\
\text { invasive methods as venipuncture. Saliva could be obtained by non- } \\
\text { invasive procedure, acceptable for children, and it contains small amounts } \\
\text { of IgG from mucosal and gingival crevicular fluid. Available antibody } \\
\text { detection methods are focused in serum samples, with low sensitivity and } \\
\text { few reports of alternative biological material, like saliva. Here, we } \\
\text { standardized immunoassays with high sensitivity for detection of anti-T. } \\
\text { gondii IgG in paired saliva and serum sample from 20 adult volunteers, } \\
\text { which allows DOT-ELISA and a Protein A IgG capture assay. The sensitivity } \\
\text { and specificity of the saliva DOT-ELISA were similar to sera ELISA. We also } \\
\text { tested 100 saliva samples from university graduates in all assays, showing } \\
\text { 19\% (95\%CI 12-28\%) frequency of toxoplasmosis in this group, lower } \\
\text { than reported for our area. Protein A IgG capture saliva assay was also } \\
\text { efficient with similar results. Immunoassay with saliva IgG for } \\
\text { toxoplasmosis is a very promising tool for use for the epidemiology of } \\
\text { toxoplasmosis in children or other protected groups. This work was } \\
\text { supported by LIMHCFMUSP and CAPES. }\end{array}$ \\
\hline Abstractis \\
\hline
\end{tabular}




\section{Saliva as a source of anti-Toxoplasma gondii IgG for enzyme immunoassay}

Barbara Fialho Carvalho Sampaio, B.Sc. ${ }^{1}$

Miriam de Souza Macre, M.Sc., Ph.D. ${ }^{2}$

Luciana Regina Meireles, D.V.M., M.Sc., Ph.D. ${ }^{1}$

Heitor Franco de Andrade Junior, M.D., Ph.D. 1,3

1 -Laboratório de Protozoologia, Instituto de Medicina Tropical de São Paulo Av.Dr.Eneas de Carvalho Aguiar, 470 05403-000, S.Paulo, BRAZIL \& 2Instituto de Ciências Biomédicas \& 3 Faculdade de Medicina - Universidade de São Paulo

Running title: saliva immunoassay for toxoplasmosis;

Key words: Immunoassay, ELISA, Dot-ELISA, toxoplasmosis, saliva

Corresponding author

H.F.Andrade Jr.

Av.Dr.E.C.Aguiar, 470

05403-000 - São Paulo, Brazil

Phone $+55+11+30617010$

E-mail hfandrad@usp.br 


\section{Introduction}

Worldwide distributed zoonosis, toxoplasmosis is caused by Toxoplasma gondii, which is an obligate intracellular Apicomplexa parasite. This protozoan can infect all warm blooded animals, including human beings, domestic and wild animals but its only definitive hosts are felids, which can be infected by the predation of animals containing tachyzoites or cysts in their tissues [5].

This disease usually presents few or no symptoms, but severe acute disease can occur on rare occasions, with pneumonitis, miocarditis and encephalitis [12]. The parasite was identified by PCR in blood, cerebrospinal fluid, saliva and bone marrow aspirate or by immunohistochemistry in biopsies of the spleen or lymph nodes, as well as in infiltrated skin; but its isolation and cultivation is rarely obtained [2]. The main tool used for the diagnosis of toxoplasmosis is serology, and several serum tests were recommended for the diagnosis of toxoplasmosis [4]. The Dot-ELISA has been described as an efficient diagnostic method for infectious parasitic diseases such as Cutaneous Leishmaniasis [25], schistosomiasis [21], toxoplasmosis [18],and angiostrongyliasis [6].

Most antibody detection assays use blood or serum as a source of antibodies for diagnostic purposes; but other biological components could also be used, such as saliva. Several studies have examined the potential of saliva as a biological fluid for laboratory diagnostic tests [17]. Its was first used in diagnostic testing for monitoring drugs and hormones [8] and it was then applied in the diagnosis of infectious diseases of different origins such as fungal infections [10], parasitic diseases such as schistosomiasis [26], toxoplasmosis [14], neurocysticercosis [7]) and viral infections [20]. Saliva is a specific fluid secretion from salivary glands such as the parotid, submandibular, sublingual and minor glands, together with substances derived from the gingival crevicular fluid, bronchial secretions or nasal squamous epithelial cells, food debris, microorganisms and their metabolic products [11]. The immunoglobulin present in saliva is derived from the salivary glands and blood serum. There is a predominance of secretory immunoglobulin $A$, which is derived from plasma cells in salivary glands and is the principal mechanism of specific immune 
response in the saliva (11). On the other hand, the immunoglobulins $G$ and $M$ are also present in saliva, derived from the serum in the gingival crevicular fluid exudate and providing more stable source than secreted saliva IgA. [16; 19]. Saliva could be used as a diagnostic fluid, being an accessible, non-invasive and easy to use source of those immunoglobulins. As a clinical tool, saliva offers many advantages over blood, including ease of collection, low cost and better comfort to the patient (especially children). This easy to handle source had other advantages due the absence of clotting or complement, thus decreasing the number of necessary manipulation steps [27]. Here, we studied saliva as a source for testing for $T$. gondii antibodies in young adults',we compared saliva samples to blood samples, comparing several assays to allow the use of this sensitive, rapid, inexpensive and easily applied laboratory practice.

\section{MATERIAL AND METHODS}

\section{Samples and materials}

We tested 20 serum and saliva samples from volunteers and 100 saliva samples from 18-21 years old graduation students from a public University. All samples were collected after their informed consent and this project is approved by the Ethics Committee of Medical College and the University of São Paulo under no. 031/11.

Mice were supplied by our colony and T.gondii strains were cryopreserved at the laboratory as previously reported [14]. All chemicals and reagents were supplied by commercial sources unless specified.

\section{Methods}

\section{T.gondii antigens}

All antigen preparation was performed on tachyzoites from $\mathrm{RH}$ strain obtained by peritoneal washings of infected mice and purified by centrifugation and filtration in polycarbonate filters for host cell removal as elsewhere reported [14] All reactions were performed with a large single round of antigen preparation

\section{Biotin labeling of high molecular weight saline T.gondii antigen}


Biotin conjugated antigen was labeled with NHS-caproate Biotin and high molecular weight saline T.gondii antigen, purified by molecular exclusion chromatography and purified with adding of bovine albumin to $1 \mathrm{mg} / \mathrm{ml}$. This conjugated antigen was standardized to be used as a 1/50 dilution.

\section{Immunoassays}

\section{ELISA (Enzyme - Linked Immunosorbent Assay, Engwall \& PerImann, 1972)}

Polystyrene plates of 96 wells microtitre (Costar $\AA$ ) were sensitized over night with $100 \mu \mathrm{l} /$ well $10 \mu \mathrm{g} / \mathrm{ml} \mathrm{T}$. gondii soluble antigen suspended in $0.1 \mathrm{M} \mathrm{pH} 9.5$ sodium carbonate buffer. After blocking with $3 \%$ solution skim milk (Molico $®$ ) in PBS pH 7.2 containing $0.02 \%$ Tween 20, the plates were washed again three times and samples were added of serum and saliva appropriately diluted in PBST containing 5\% skim milk, with $1 \mathrm{~h} 37^{\circ} \mathrm{C}$ incubation. After washes, wells were incubated with anti human IgG peroxidase conjugate for 1 hour at $37^{\circ} \mathrm{C}$. After washings, bound conjugate was reacted with specific substrate, $0^{-}$ phenilene diamine( OPD) $4 \mathrm{ug} / \mathrm{ml}$ or Tetramethylbenzidine(TMB) $0.4 \mathrm{ug} / \mathrm{ml}$ in Na-citrate buffer $0.05 \mathrm{M} \mathrm{pH} 5.8$ containing $0.03 \% \mathrm{H}_{2} \mathrm{O}_{2}$. After $30 \mathrm{~min}$ at $37^{\circ} \mathrm{C}$, the reaction was stopped by adding $1 / 10$ volume of $4 \mathrm{~N} \mathrm{HCl}$ or $2 \mathrm{~N} \mathrm{H}_{2} \mathrm{SO}_{4}$. Specific optical density for OPD(495 nm) or TMB(450 nm) was determined in automated microplate reader (Labsystems Multiskan MS).

\section{Dot-ELISA}

The technique of Dot-ELISA was performed according to the elsewhere described method [8], with modifications. We briefy used nitrocellulose membrane and a dot blot 96 well DOT-BLOT system (BioRad $®$ ). Each well was sensitized with $50 \mathrm{ul} /$ well with soluble antigen of $T$. gondii, suspended in buffer $0.1 \mathrm{M}$ carbonate-bicarbonate $\mathrm{pH} 9.5$ at concentrations of $0.5 \mathrm{mg} / \mathrm{mL}$ to screen for serum and $1.5 \mathrm{mg} / \mathrm{mL}$ of antigen for saliva samples, using a (BioRad ${ }^{\circledR}$ ). After sensitization, the membranes were removed from the dot blot system, cut into strips of approximately $0.4 \mathrm{~mm}$ and placed in incubation trays with $10.5 \mathrm{~cm} \times 5 \mathrm{~mm}$ troughs (BioRad ${ }^{\circledR}$ ), which were blocked for 2 hours at room temperature with PBSTL 5\%. Membranes were washed three times for 5 minutes with $0.05 \%$ PBST with agitation. In each well we applied $500 \mu \mathrm{L} /$ troughs 
volumes of serum or saliva, incubated for 1 hour under agitation at room temperature. After incubation, the membranes were washed again three times and $500 \mu \mathrm{L} /$ troughs conjugated anti - human IgG at a dilution of 1/10.000 were applied with 1 hour incubation at room temperature. After the incubation, the membranes were washed again 3 times. The reaction was detected using $500 \mu \mathrm{L} /$ troughs of chromogen solution 3,3 - Diaminobenzidine (DAB) $1 / \mathrm{mg} / \mathrm{ml}$ in PBS containing $0.045 \% \mathrm{H}_{2} \mathrm{O}_{2}$. The reactions were carefully observed and when background staining appeared in the membrane, the troughs were immediately washed with ice cold PBS, dried and digitalized.

\section{Protein A Dot-ELISA}

The Dot-ELISA technique was performed as described above except that each lane was adsorbed with $50 \mu \mathrm{l} /$ well of $T$. gondii soluble antigen or recombinant Protein A (Repligen) suspended at $0,5 \mathrm{mg} / \mathrm{mL}$ in $\mathrm{pH} 9.50 .1 \mathrm{M}$ carbonatebicarbonate buffer using a system 96-well dot blot (BioRad $®$ ). After sensitization, the membranes were removed from the dot blot system, cut into squares containing one dot of antigen and one dot of Protein A, blocked per 2 hours at room temperature with $3 \%$ skim milk in PBST. And incubated with $500 \mu \mathrm{L}$ of saliva, for 1 hour under while being stirred at room temperature. After incubation, conjugated anti - human IgG at a dilution of 1/10.000 was applied for 1 hour at room temperature. After three washes, the strip was revealed using DAB solution (3,3 - diaminobenzidine $10 \mathrm{mg}$ plus $10 \mathrm{ml}$ PBS and $15 \mu \mathrm{L}$ of $30 \%$ hydrogen peroxide) until the background darkened, and it was then immediately recorded with a digital camera.

\section{Protein A IgG capture ELISA}

This assay uses recombinant Staphylococcal protein $A$ in the solid phase, for binding IgG from saliva, using an biotinylated tachyzoite saline antigen for revealing specific IgG bound to protein $A$ in solid support. Polystyrene microtiter wells for 96 (Costar $®$ ) were briefly coated with protein $A$ in $0.1 \mathrm{M} \mathrm{pH} 9.5$ sodium carbonate buffer $10 \mu \mathrm{g} / \mathrm{ml}, 100 \mu \mathrm{l} /$ well for 20 hours at $4^{\circ} \mathrm{C}$ in a humid chamber. After washing and blocking with $3 \%$ solution skim milk (Molico $®$ ) in

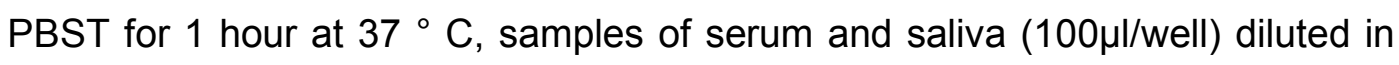
PBST containing 5\% skim milk were deposited on the plates and incubated at $37^{\circ} \mathrm{C}$ for 1 hour. After three new washes, biotinylated T.gondii antigen dilution 
was incubated for $1 \mathrm{~h}$ at $37^{\circ} \mathrm{C}$. After washings, avidin-peroxidase was added and incubated for $1 \mathrm{~h}$ at $37^{\circ} \mathrm{C}$. The reaction was revealed with different chromogens as OPD and TMB, as above described in ELISA. Specific OD were determined in an automatic microplate reader (Labsystems Multiskan MS).

\section{STATISTICAL ANALYSIS}

Sensitivity, specificity, positive and negative predictive values with $95 \%$ confidence intervals were calculated comparing with serum specified golden test using Epilnfo 6.04(CDC, USA),

\section{RESULTS \\ Dot-ELISA}

We used 20 samples of saliva with their respective sera for standardization, stored at the bank of biological material from the laboratory of Protozoology IMSTSP. These samples were tested by Dot-ELISA in quadruplicate facing different antigen preparations, with results shown in fig.1. Relative sensitivity, relative specificity and positive and negative predictive value of each antigen were calculated using Epilnfo 6.04, using the serum ELISA as a reference test, shown in table 1 , showing the high efficiency of the assay.

The Dot-ELISA showed results consistent with both samples of serum and saliva, with $100 \%$ sensitivity and $100 \%$ specificity, and the most promising antigen for future testing. We also performed a Dot-ELISA Protein A confirmatory test on those samples using one spot absorbed with protein $A$ for $\lg$ detection and another with T.gondii antigen for specific IgG detection in negative samples that could be ascribed to the absence of $\lg$ in saliva samples, as described in Methods. We found detection of IgG in all saliva samples, either negative or positive control samples, as can be seen in the figure 1.

\section{Dot-ELISA in field samples}

We tested 100 saliva samples from young adult volunteers with Dot-ELISA assay and also using the confirmatory protein A IgG as a binding stop for each sample. Saliva samples were assayed as described in Methods. The dried spots were consolidated in figure 2. As can be seen, all saliva samples presented IgG and 19 samples were clearly positive for anti-T.gondii IgG 
antibodies in the spot. This data provide a frequency of $19 \%(12.1-28.395 \%$ confidence interval).

\section{Protein A IgG capture ELISA}

We performed this assay using ELISA plates adsorbed with protein $A$ for binding to the immunoglobulin Fc portion, with exposure of the Fab antigen reacting fraction. Specificity was tested with biotinylated T.gondii antigen and avidin-peroxidase as described in Methods, using two peroxidase substrates with diverse sensibilities to detect anti-T.gondii IgG. We tested the same 100 saliva samples from the volunteers of the above experiments, as can be seen in figure 3. All samples presented almost the same reactivity on the Dot-ELISA, but the distinction between positive and negative samples was more evident when TMB was used despite the same distinction of OPD, although of lesser intensity.

Using Dot-ELISA data as a gold standard allowing the determination of serology efficiency indexes using these two chromogens; as can be seen in table 2, we found that TMB is more sensitive than OPD which is more specific, but the first chromogen was much more reactive, as expected. 


\section{DISCUSSION}

This approach to collecting saliva is extremely important for specific groups of patients such as children, which are often protected from conventional invasive blood collection. Most mothers or caretakers avoid the venipuncture process for collection of blood in children, especially for a non-vaccine protected or lethal disease. Our data show that the Dot-ELISA immunoassay detects IgG antibodies to $T$. gondii in saliva with the same efficiency as serum detection, the most commonly used material for this purpose. This has an important implication for the diagnosis of infectious diseases, in particular toxoplasmosis, since it allows the use of an easy to obtain material, without need for invasive methods of collection, such as blood collection. We confirmed this efficiency using a large sample of saliva from young adults from our university, with both more efficient Dot-ELISA or a protein A capture ELISA assay. This saliva collection approach has also shown positive results for groups of adults in patient adherence studies, since it increases the confidence and perseverance of those in treatment since there is no need for invasive needle use during each consultation, thereby avoiding absenteeism [23]. In our study, a standardized test of Dot-ELISA with high sensitivity and specificity allowed for the detection of IgG in small amounts of material, which is extremely important in the case of saliva since it has low concentration of IgG. Other authors had previously reported the importance and applicability of the reaction of Dot-ELISA for other protozoan infections such as Chagas disease [15], but for toxoplasmosis, data are scarce [1] when using serum as source of antibodies. In toxoplasmosis, there are reports on the use of saliva for antibodies from ELISA and immunoblotting [9; 13; 24], and our pioneering work in using the technique of Dot-ELISA for saliva. Our data show that standardization with the saline extract antigen showed the best results in the Dot-ELISA, allowing a clear distinction between positive and negative samples. These results are supported by data reported by other authors [1, 18] who used the Dot-ELISA with saline for antigen detection of $\operatorname{lgG}$ anti-T. gondii in serum samples. Our results were also similar to those described by Morris et al. (2002) in studies on detecting anti- 
rubella IgG antibodies in saliva or the pioneering study on the detection of antiT. gondii in saliva, $[9,14]$ We also confirmed the presence of IgG in saliva in our assay. The absence or low amounts of IgG in saliva could be responsible for low efficiency of some Dot-ELISA assays, as elsewhere reported, without this careful control [22]. We were also able to standardize and use a protein $A$ capture assay for anti-T.gondii IgG detection, similar to reported by others in the development of tests for antibody capture in biological fluids [28]. Many studies support the idea that the more advanced the age of the volunteers, the greater the rate of serology positivity for toxoplasmosis [29]; our results showed a $19 \%$ frequency, which is lower in comparison with other Brazilian samples, such as $50 \%$ frequency in teenagers in low income neighborhoods in the same city [14] or $>70 \%$ in adults in Brazilian Amazon [3]. We attributed this low frequency to the high income origin of our sample.

The Dot-ELISA and protein A capture ELISA for the detection of IgG anti- $T$. gondii in saliva is very promising as a tool: since it uses a non-invasive method of collection; high sensitivity, high specificity, low cost and ease of operation in the routine laboratory. It also allows the development of epidemiological studies and the development of rapid commercial tests with small amounts of saliva.

\section{Acknowledegments}

We gratefully thank Claudio C. J. Ekman for sampling procedures and all volunteers for their kind supply of saliva or blood. H.F.Andrade Jr was a fellow of CNPq. Barbara F.C.Sampaio was a fellow of CAPES and part of this work was used for her Master's degree. This work was partially supported by LIMHCFMUSP.

\section{References}

1. Brooks RG, Sharma SD, Remington JS. Detection of Toxoplasma gondii antigens by a dot-immunobinding technique. J Clin Microbiol. 1985 Jan;21(1):113-6.

2. Buxton D, Innes EA. A commercial vaccine for ovine toxoplasmosis. Parasitology. 1995;110 Suppl:S11-6.

3. Cavalcante GT, Aguilar DM, Camargo LM, Labruna MB, de Andrade HF, Meireles LR,Dubey JP, Thulliez P, Dias RA, Gennari SM. 
Seroprevalence of Toxoplasma gondii antibodies in humans from rural Western Amazon, Brazil. J Parasitol. 2006Jun;92(3):647-9.

4. Cimerman, B., Cimerman, S. Parasitologia Humana e seus Fundamentos Gerais. In: Amato Neto, V., Marchi, C.R. Toxoplasmose. Ed. Atheneu, São Paulo, p.151-181, 1999.(Portuguese)

5. Dubey JP, Kotula AW, Sharar A, Andrews CD, Lindsay DS. Effect of high temperature on infectivity of Toxoplasma gondii tissue cysts in pork. J Parasitol. 1990 Apr;76(2):201-4.

6. Eamsobhana P, Ongrotchanakun J, Yoolek A, Punthuprapasa P, Monkong N, Dekumyoy P. Multi-immunodot for rapid differential diagnosis of eosinophilic meningitis due to parasitic infections. J Helminthol. 2006 Sep;80(3):249-54.

7. Feldman $M$, Plancarte $A$, Sandoval $M$, Wilson $M$, Flisser $A$. Comparison of two assays (EIA and EITB) and two samples (saliva and serum) for the diagnosis of neurocysticercosis. Trans R Soc Trop Med Hyg. 1990 Jul-Aug;84(4):559-62.

8. Haeckel R. Procedures for saliva sampling. J Clin Chem Clin Biochem. 1989 Apr;27(4):246-7.

9. Hajeer $\mathrm{AH}$, Balfour AH, Mostratos A, Crosse B. Toxoplasma gondii: detection of antibodies in human saliva and serum. Parasite Immunol. 1994 Jan;16(1):43-50.

10. Jeganathan S, Ufomata D, Hobkirk JA, Ivanyi L. Immunoglobulin A1 and A2 subclass of salivary antibodies to Candida albicans in patients with oral candidiasis. Clin Exp Immunol. 1987 Nov;70(2):316-21.

11. Kaufman E, Lamster IB. The diagnostic applications of saliva--a review. Crit Rev Oral Biol Med. 2002;13(2):197-212. Review.

12. Leal FE, Cavazzana CL, de Andrade HF Jr, Galisteo AJ Jr, de Mendonça JS, Kallas EG. Toxoplasma gondii pneumonia in immunocompetent subjects: case report and review. Clin Infect Dis. 2007 Mar 15;44(6):e62-6.

13. Loyola AM, Durighetto AF Jr, Silva DA, Mineo JR. Anti-Toxoplasma gondii immunoglobulins $A$ and $G$ in human saliva and serum. J Oral Pathol Med. 1997 Apr;26(4):187-91. 
14. Macre Mde S, Pires M, Meireles LR, Angel SO, Andrade HF Jr. Serology using rROP2 antigen in the diagnostic of toxoplasmosis in pregnant women. Rev Inst Med Trop Sao Paulo. 2009 SepOct;51(5):283-8.

15. Matsumoto TK, Hoshino-Shimizu S, Nakamura PM, Andrade HF Jr, Umezawa ES. High resolution of Trypanosoma cruzi amastigote antigen in serodiagnosis of different clinical forms of Chagas' disease. J Clin Microbiol. 1993 Jun;31(6):1486-92.

16. Mortimer PP, Parry JV. Detection of antibody to HIV in saliva: a brief review.Clin Diagn Virol. 1994 Aug;2(4-5):231-43.

17. de Moura L, Bahia-Oliveira LM, Wada MY, Jones JL, Tuboi SH, Carmo EH, Ramalho WM, Camargo NJ, Trevisan R, Graça RM, da Silva AJ, Moura I, Dubey JP, Garrett DO.Waterborne toxoplasmosis, Brazil, from field to gene. Emerg Infect Dis. 2006 Feb;12(2):326-9.

18. Pappas MG, Lunde MN, Hajkowski R, McMahon J. Determination of IgM and IgG antibodies to Toxoplasma using the IFA test, ELISA, and Dot-ELISA procedures. Vet Parasitol. 1986 Mar;20(1-3):31-42.

19. Parry JV, Perry KR, Mortimer PP. Sensitive assays for viral antibodies in saliva: an alternative to tests on serum. Lancet. 1987 Jul 11;2(8550):72-5.

20. Perry KR, Brown DW, Parry JV, Panday S, Pipkin C, Richards A. Detection of measles, mumps, and rubella antibodies in saliva using antibody capture radioimmunoassay. J Med Virol. 1993 Jul;40(3):235-40.

21. Pinto PL, Kanamura HY, Silva RM, Rossi CR, de Andrade Júnior HF, Amato Neto V.Dot-ELISA for the detection of $\lg M$ and $\lg G$ antibodies to Schistosoma mansoni worm and egg antigens, associated with egg excretion by patients. Rev Inst Med Trop Sao Paulo. 1995 MarApr;37(2):109-15.

22. Shukla N, Husain N, Agarwal GG, Husain M. Utility of cysticercus fasciolaris antigen in Dot-ELISA for the diagnosis of neurocysticercosis. Indian J Med Sci. 2008 Jun;62(6):222-7.

23. Stekler JD, Swenson PD, Coombs RW, Dragavon J, Thomas KK, Brennan CA, Devare SG, Wood RW, Golden MR. HIV testing in a high- 
incidence population: is antibody testing alone good enough? Clin Infect Dis. 2009 Aug 1;49(3):444-53.

24. Stroehle A, Schmid K, Heinzer I, Naguleswaran A, Hemphill A. Performance of a Western immunoblot assay to detect specific antiToxoplasma gondii IgG antibodies in human saliva. J Parasitol. 2005 Jun;91(3):561-3.

25. Walton BC, Benchoff BM, Brooks WH. Comparison of the indirect fluorescent antibody test and methylene blue dye test for detection of antibodies to Toxoplasma gondii. Am J Trop Med Hyg. 1966 Mar;15(2):149-52.

26. Wang Z, Xue C, Lou W, Zhang X, Zhang E, Wu W, Shen G. Noninvasive immunodiagnosis of Schistosomiasis japonica: the detection of specific antibodies in saliva. Chin Med J (Engl). 2002 Oct;115(10):14604.

27. Wong DT. Salivary diagnostics: scientific and clinical frontiers. Adv Dent Res. 2011 Oct;23(4):350-2.

28. Yang J, Jin M, Chen J, Yang Y, Zheng P, Zhang A, Song Y, Zhou H, Chen $\mathrm{H}$. Development and evaluation of an immunochromatographic strip for detection of Streptococcus suis type 2 antibody. J Vet Diagn Invest. 2007 Jul;19(4):355-61.

29. Zarkovic A, McMurray C, Deva N, Ghosh S, Whitley D, Guest S. Seropositivity rates for Bartonella henselae, Toxocara canis and Toxoplasma gondii in New Zealand blood donors. Clin Experiment Ophthalmol. 2007 Mar;35(2):131-4. Erratum in: Clin Experiment Ophthalmol. 2007 Jul;35(5):500. 
Figure captions

Table 1 - Serology efficiency indexes of Dot-ELISA using saliva or serum, with $95 \%$ confidence interval.

Table 2 - Serology efficiency indexes of protein A capture anti T.gondii IgG assays, as related to revealing chromogen.

FIGURE 1: Dot-ELISA results, using paired saliva and serum samples Arrows indicate positive samples. Upper lanes Dot-ELISA was performed using serum or saliva in quadruplicates. Lower lane, confirmatory Dot-ELISA in saliva samples using protein A for IgG capture in upper dots.

Figure 2: Protein A capture IgG or antiT.gondii lgG in students saliva samples. Each sample was composed by one confirmatory dot for IgG presence in saliva samples, (Protein A right dot) or anti-T.gondii IgG (T.gondii antigen left dot), revelade with anti human IgG. Positive anti T.gondii $(n=19)$ samples could be seen at left.

Figure 3: Protein A IgG capture ELISA assay for 100 samples of human saliva, using T. gondii biotinylated antigen, revealed with OPD or TMB. Dot-ELISA Positive $(+)=$ closed symbols and Dot-ELISA Negative $(-)=$ open symbols TMB(circles) or OPD(squares). $Y$ axis was divided at the threshold of $95 \%$ confidence interval cutoff of negative samples. Mean and SEM bars are also shown for each sample. 


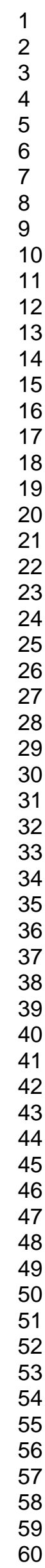

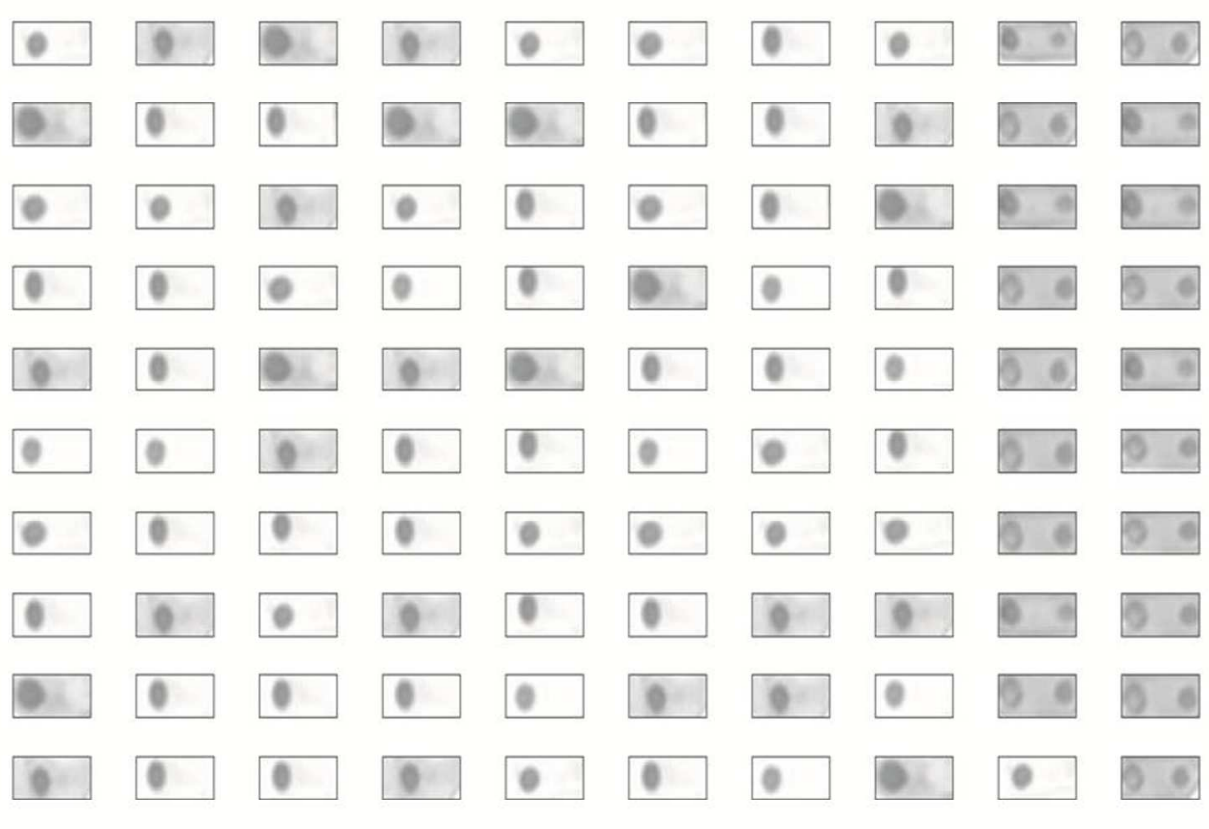

$254 \times 190 \mathrm{~mm}(96 \times 96 \mathrm{DPI})$ 


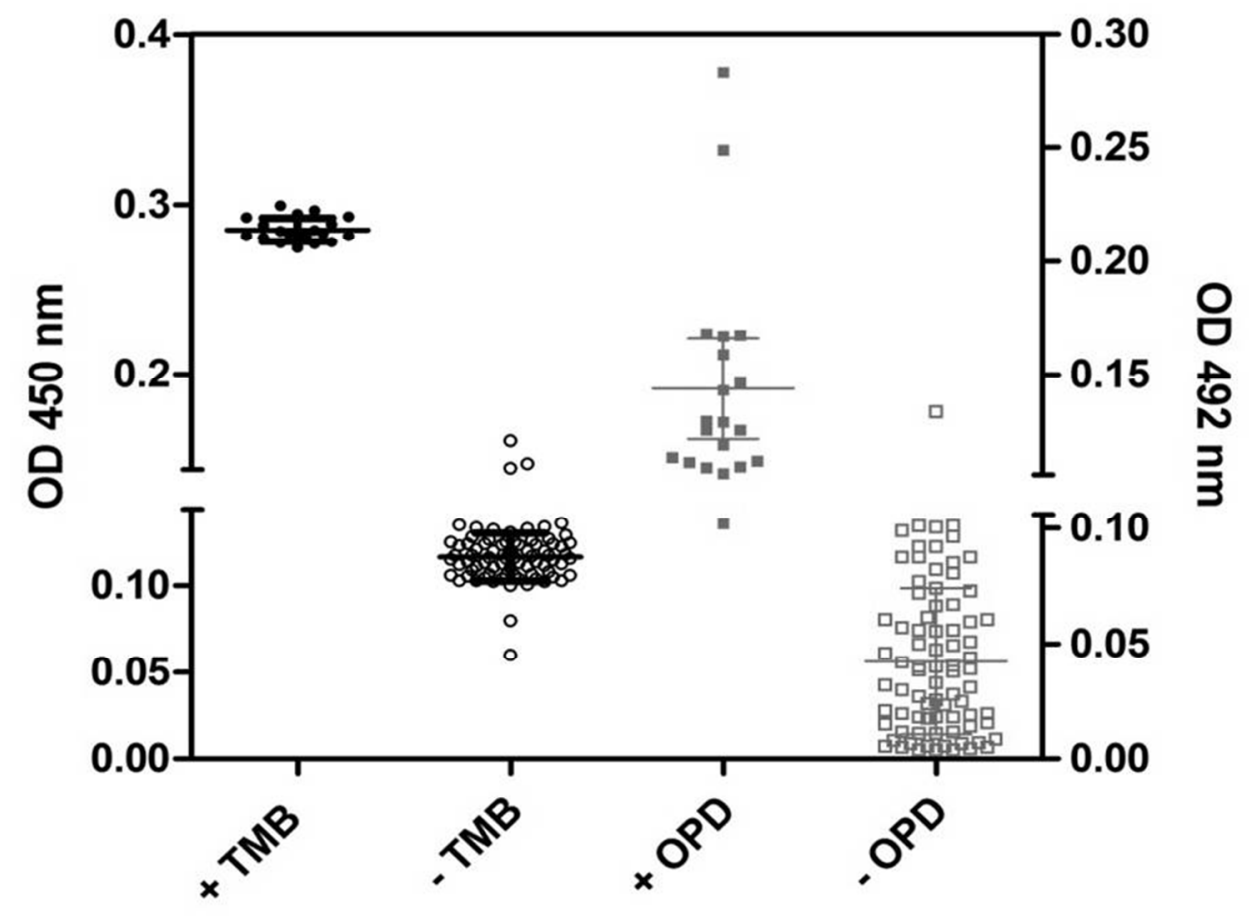

$254 \times 190 \mathrm{~mm}(96 \times 96$ DPI $)$ 
Table 1 - Serology efficiency indexes of DOT ELISA using saliva or serum, with $95 \%$ confidence interval.

\begin{tabular}{l|c}
\hline DOT-ELISA & Saliva vs serum \\
\hline Sensitivity & $100 \%$ \\
(95\% Confidence interval) & $(9.2-90.8)$ \\
\hline Specificity & $100 \%$ \\
(95\% Confidence interval) & $(75.9-100.0)$ \\
\hline Predictive value (+) & $100 \%$ \\
95\% Confidence interval) & $(19.8-100.0)$ \\
\hline Predictive value (-) & $100 \%$ \\
(95\% Confidence interval) & $(63.9-98.1)$ \\
\hline
\end{tabular}


Table 2 - Serology efficiency indexes of protein A capture anti T.gondii IgG assays, as related to revealing chromogen.

\begin{tabular}{l|c|c}
\hline \multirow{2}{*}{ Index } & \multicolumn{2}{|c}{ Assayed chromogen } \\
\cline { 2 - 3 } & $\begin{array}{c}\text { TMB } \\
(95 \% \text { Confidence } \\
\text { interval })\end{array}$ & $\begin{array}{c}\text { OPD } \\
(95 \% \text { Confidence } \\
\text { interval })\end{array}$ \\
\hline Sensitivity & 1,000 & 0,9474 \\
& $(0.8235$ to 1.000$)$ & $(0.7397$ to 0.9987$)$ \\
\hline Specificity & 0,9630 & 0,9877 \\
& $(0.8956$ to 0.9923$)$ & $(0.9331$ to 0.9997$)$ \\
\hline Negitive Predictive Value" & 0,8636 & 0,9474 \\
& $(0.6509$ to 0.9709$)$ & $(0.7397$ to 0.9987$)$ \\
\hline
\end{tabular}

